\title{
Tomatoes as functional food
}

Citation for published version (APA):

Hazewindus, M. (2012). Tomatoes as functional food. [Doctoral Thesis, Maastricht University]. Maastricht University. https://doi.org/10.26481/dis.20121206mh

Document status and date:

Published: 01/01/2012

DOI:

10.26481/dis.20121206mh

Document Version:

Publisher's PDF, also known as Version of record

\section{Please check the document version of this publication:}

- A submitted manuscript is the version of the article upon submission and before peer-review. There can be important differences between the submitted version and the official published version of record.

People interested in the research are advised to contact the author for the final version of the publication, or visit the DOI to the publisher's website.

- The final author version and the galley proof are versions of the publication after peer review.

- The final published version features the final layout of the paper including the volume, issue and page numbers.

Link to publication

\footnotetext{
General rights rights.

- You may freely distribute the URL identifying the publication in the public portal. please follow below link for the End User Agreement:

www.umlib.nl/taverne-license

Take down policy

If you believe that this document breaches copyright please contact us at:

repository@maastrichtuniversity.nl

providing details and we will investigate your claim.
}

Copyright and moral rights for the publications made accessible in the public portal are retained by the authors and/or other copyright owners and it is a condition of accessing publications that users recognise and abide by the legal requirements associated with these

- Users may download and print one copy of any publication from the public portal for the purpose of private study or research.

- You may not further distribute the material or use it for any profit-making activity or commercial gain

If the publication is distributed under the terms of Article $25 \mathrm{fa}$ of the Dutch Copyright Act, indicated by the "Taverne" license above, 
TOMATOES AS FUNCTIONAL FOOD 
(C) 2012, M. Hazewindus

The studies presented in this thesis were performed within NUTRIM School for Nutrition, Toxicology and Metabolism and which participates in MUMC+ (Maastricht University Medical Centre).

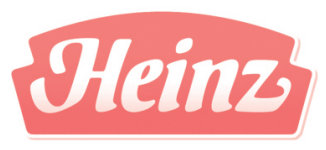

Financial support for printing of this thesis was kindly provided by the H.J. Heinz Company. 


\section{Tomatoes as functional food}

\section{Proefschrift}

Ter verkrijging van de graad van doctor aan de Universiteit Maastricht,

op gezag van de Rector Magnificus, Prof. Mr. G.P.M.F. Mols,

volgens het besluit van het College van Decanen,

in het openbaar te verdedigen op donderdag 6 december 2012 om 14.00 uur

Door

Merel Hazewindus

Geboren te Reimerswaal op 15 oktober 1974 
PROMOTOR

Prof. dr. A. Bast

CO-PROMOTORES

Dr. G.R.M.M. Haenen

Dr. A.R. Weseler

BEOORDELINGSCOMMISSIE

Prof. Dr. M.S. Westerterp-Plantenga (voorzitter) (MUMC+, Maastricht)

Prof. Dr. W. Stahl (Heinrich-Heine Universitat, Düsseldorf, Germany)

Prof. Dr. Ir. D. Kromhout (Wageningen University and Research centre, Wageningen)

Prof. Dr. C.G. Schalkwijk (MUMC+, Maastricht)

Prof. Dr. E.C.M. Mariman (MUMC+, Maastricht) 
There was something formless and perfect before the universe was born.

It is serene. Empty. Solitary.

Unchanging. Infinite. Eternally present.

It is the Mother of the universe.

For lack of a better name, I call it the Too.

It flows through all things, inside and outside, and returns to the origin of all things.

The Too is great.

The universe is great.

Earth is great.

Mon is great.

These are the four great powers.

Mon follows the earth.

Earth follows the universe.

The universe follows the To.

The Too follows only itself.

TAO TE CHING 25 - LAO TIU 



\section{Contents}

\section{CHAPTER 1}

General introduction, aim and outline

CHAPTER 2

Tomatoes and inflammation: an overview

\section{CHAPTER 3}

The anti-inflammatory effect of lycopene complements the antioxidant action of ascorbic acid and $\alpha$-tocopherol

\section{CHAPTER 4}

$\alpha$-Tocopherol, lycopene, $\beta$-carotene and lutein reduce the activities of protein kinase $C-\alpha, \beta I$ and $\delta$

CHAPTER 5

Protection against chemotaxis in the anti-inflammatory effect of tomato ketchup

CHAPTER 6

The protective potential of tomato ketchup consumption on inflammation induced ex-vivo in human blood

\section{CHAPTER 7}

General discussion and future perspectives

Algemene discussie en toekomstperspectieven 
Cet me entertoin you 

CHAPTER 1

General introduction, aim and outline 


\section{Abbreviations}

CRP C-reactive protein

CVD Cardiovascular disease

DNA Deoxyribonucleic acid

HDL High density lipoprotein

HNE 4-hydroxy-2,3-trans-nonenal

ICAM-1 Intercellular adhesion molecule-1

LDL Low density lipoprotein

IL Interleukin

IкB Inhibitor kappa B

LPS Lipopolysaccharide

MCP-1 Monocyte chemoatractant protein-1

MDA Malondialdehyde

$\mathrm{NAD}^{+} \quad$ Nicotinamide adenine dinucleotide

NADPH Reduced nicotinamide adenine dinucleotide phosphate

NFKB Nuclear factor-kappa B

PKC Protein kinase $C$

PUFA Poly unsaturated fatty acid

RNS Reactive nitrogen species

ROS Reactive oxygen species

TBARS Thiobarbituric acid reactive substances

TNF- $\alpha$ Tumor necrosis factor- alpha

VCAM-1 Vascular cell adhesion molecule-1

VLDL Very low density lipoprotein 


\section{General introduction}

Cardiovascular diseases are a major cause of deaths worldwide. Lifestyle factors such as unbalance diets, work related stress and inactivity have been acknowledged to increase the risk for developing cardiovascular diseases, cancer and osteoporosis. These disorders are featured by persistent low grade inflammation. Frequent consumption of fruits and vegetables seem to protect against chronic inflammatory disorders. In the Western diet, tomato-fruits or tomato products such as ketchup are regularly consumed. To substantiate the health benefit of this fruit, the molecular mechanism involved needs to be elucidated. It is the primary goal of nutritional research to determine the health benefits of nutrition. Therefore, this thesis addresses to investigate the mechanisms underlying the potential health benefit of tomatoes and tomato ketchup. 


\section{Aim and outline of this thesis}

Chapter 2 gives an overview of the nutrient composition of tomatoes. In addition, an introduction of the inflammatory process, its consequences and the scientific evidence of the effect of the main constituents in tomatoes on the inflammatory process has been reviewed.

In chapter 3 cooperation between the isolated phytochemicals lycopene, ascorbic acid and $\alpha$-tocopherol are studied in two different models of processes involved in the inflammatory response.

In chapter 4 , the effect of isolated carotenoids (lycopene, $\beta$-carotene and lutein) and $\alpha$-tocopherol on PKC activity is studied.

In chapter 5, the anti-inflammatory potential of tomato ketchup was examined in human monocyte - endothelial cell interactions. Separate reactions of inflammatory processes were studied as well as an integrated process with a chemotaxis bioassay.

The promising results of the previous studies formed the basis to extent our research to investigate the functional effects of tomatoes in healthy human volunteers as described in chapter 6 . After a single consumption of tomato ketchup the blood of the volunteers was collected and inflammatory challenged with (LPS), to determine the release of inflammatory cytokines. The chemotaxis of monocytes was studied with a functional chemotaxis bioassay.

Finally, in chapter 7 the findings of this thesis are discussed and complemented with recommendations and future perspectives on the impact of tomatoes and tomato ketchup on health. 
The wise man is one who, lenows, what he does not know.

TAO TE CHING, LAO TZU 

CHAPTER 2

Tomatoes and inflammation:

an overview 


\subsection{Tomatoes and tomato products}

Tomatoes are originated in South America and were spread by Spanish conquistadors around the world. The European cultivation of tomatoes started around 1540 in Spain. Although the tomato was frequently consumed in the Mediterranean countries, in Great Britain and North America, tomatoes were thought to be poisonous. This idea existed since tomatoes are a member of the deadly nightshade family. This opinion changed in the late $18^{\text {th }}$ century and tomatoes were more regularly consumed. Nowadays the average annual fresh tomato consumption is $18 \mathrm{~kg}$ per European and $8 \mathrm{~kg}$ per capita in the US $(1,2)$. Tomatoes form the base of many products such soups, drinks and sauces, which has increased the popularity and the daily intake of the fruit. It has been assumed that the most frequently consumed tomato sauce in the Western world is tomato ketchup (2). Fresh tomatoes and many tomato products are considered to be healthy, which is supported by epidemiological and clinical studies (3-7). Data from these studies revealed that frequent consumption of tomatoes is associated with a reduced risk for cardiovascular diseases (CVD) and cancer (7-11).

\subsubsection{The major phytochemicals in tomatoes}

The health benefits of tomatoes are attributed to their substantial variety of phytochemicals, including carotenoids, vitamins and minerals. Tomatoes contain B-vitamins and vitamin K (figure 1), and relative large quantities of the vitamins $E$ (mainly $\alpha$-tocopherol) and C (i.e. ascorbic acid). Both vitamins $E$ and $C$ are generally known for their potent antioxidant activity (12-14), whereas these compounds are also involved in other physiological processes.

Vitamin C modulates apoptosis, cell signalling, inhibits cytokine production and promotes proliferation of endothelial cells (14-19). The roles for the vitamin $\alpha$-tocopherol include the prevention of platelet aggregation and adhesion which in turn contributes to an improved endothelial function $(20,21)$. $\alpha$-Tocopherol also controls cellular processes such as differentiation, proliferation and apoptosis and inhibits the enzyme glutathione S-transferase $\pi$, an isoform of the glutathione S-transferases (GSTs) $(22,23)$. In addition, it plays a central role in the cholesterol metabolism $(24,25)$ and alters the gene transcription of activator protein-1 (AP-1) which is responsible for the regulation of gene expression of cytokines and growth factors (20, 25-27).

The carotenoid lycopene is the main phytochemical in tomatoes, and it gives ripe tomatoes their red color (28). In addition, other carotenoids, such as $\alpha$ - and $\beta$-carotene, lutein and zeaxanthin, are found in tomatoes, although in minor quantities (figure 2). 


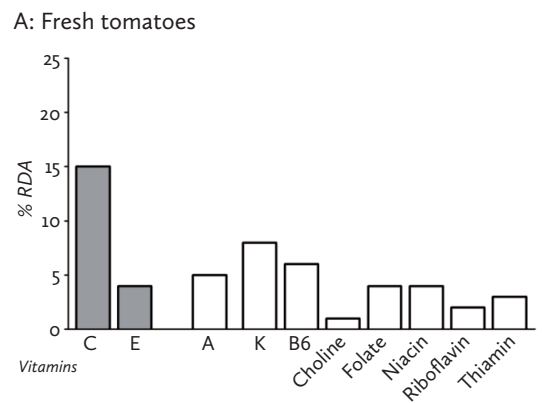

B: Tomato ketchup

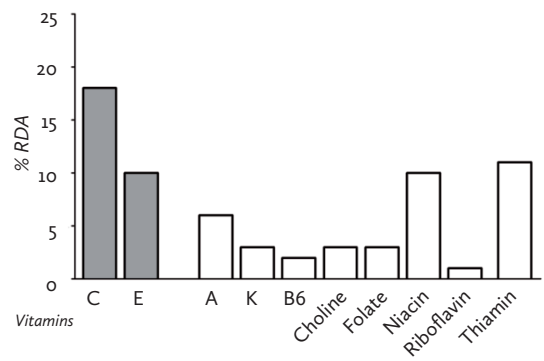

C: Tomato juice

D: Tomato paste
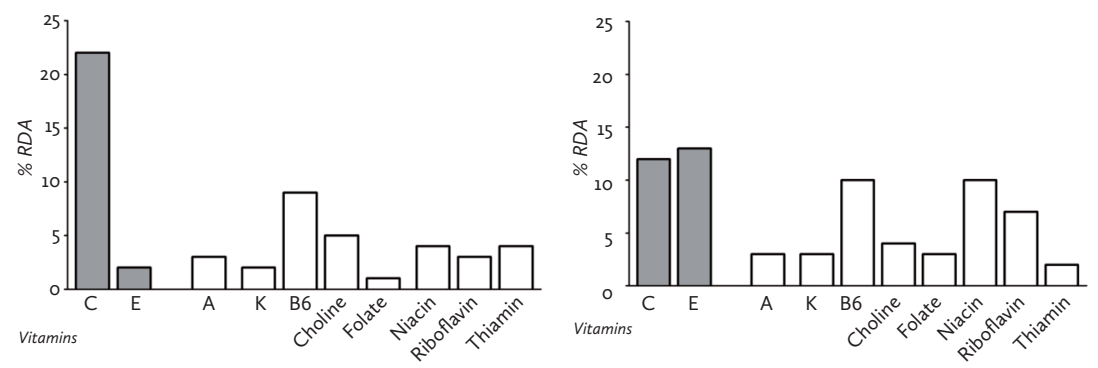

A: \% RDA for vitamin C: $15 \%$ and vitamin E: $4 \%$

B: \% RDA for vitamin C: $18 \%$ and vitamin E: $10 \%$

C: $\%$ RDA for vitamin C: $22 \%$ and vitamin E: $2 \%$

D: \% RDA for vitamin C: $12 \%$ and vitamin E: $13 \%$

Data obtained from USDA database. Vitamin content in fresh tomatoes, ketchup, tomato juice and paste and as percentage of the recommended daily allowance (RDA). 
Figure $2^{A-D}$. Carotenoid content in fresh tomatoes, tomato juice, tomato puree and tomato ketchup

A: Fresh tomatoes

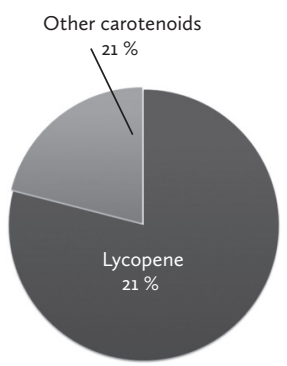

C: Tomato juice

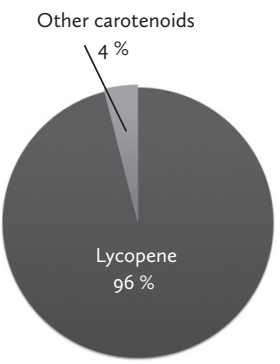

B: Tomato ketchup

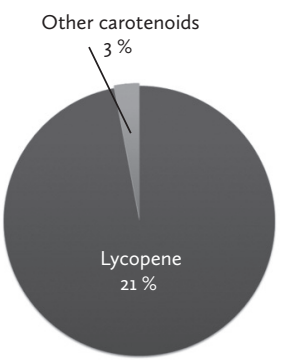

D: Tomato paste

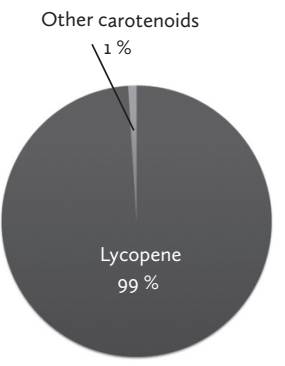

A: Total carotenoids $32.46 \mathrm{mg} / 100 \mathrm{~g}$; Lycopene $79 \%(25.73 \mathrm{mg} / 100 \mathrm{~g})$

B: Total carotenoids $17.27 \mathrm{mg} / 100 \mathrm{~g}$; Lycopene $97 \%(16.71 \mathrm{mg} / \mathrm{100g})$

C: Total carotenoids $9.37 \mathrm{mg} / 100 \mathrm{~g}$; Lycopene $96 \%$ (9.04 mg/10og)

D: Total carotenoids $22.06 \mathrm{mg} / 100 \mathrm{~g}$; Lycopene $99 \%$ (21.75 mg/10og)

Data obtained from USDA database. Total carotenoids: lycopene, $\alpha$-carotene, $\beta$-carotene, lutein and zeaxanthin

Figure 3. The chemical structure of the most common lycopene isomers

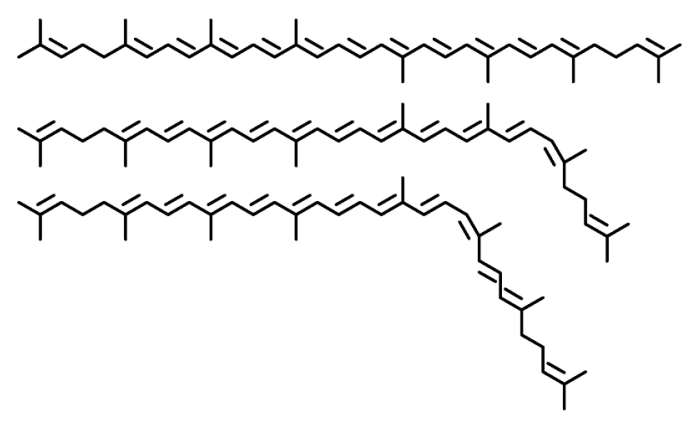


The most characteristic feature of lycopene is that it contains of a conjugated $\pi$-structure of 11 linear conjugated double bonds (figure 3$)(3,28)$. In fresh tomatoes lycopene is mainly found in the all-trans conformation (80-97\%), which is the thermodynamically most favourable form (29). Processing of tomatoes into tomato products affects the chemical structure of lycopene. Heating, cutting and also digestion in the Gl-tract can cause cis-isomerisation of lycopene. In plasma and tissues, the 5-, 9-, 13-, and 15-cis isomers are the most common forms (30).

The health benefits of lycopene range from hypocholesterolemic, cardioprotective and osteoporotic effects to anti-mutagenic activity and anti-cancer potential (31-37). Recently, the focus has shifted to the anti-inflammatory effects of tomatoes and lycopene. Several studies have reported that lycopene extracted from tomatoes effectively inhibits the inflammatory process in vitro and in vivo (38-41). However, the effect of tomato products (e.g. juice, paste, sauce) on the inflammatory process is scarcely investigated.

\subsubsection{Interaction of the main constituents in tomatoes}

In contrast to nutrition, pharmaceuticals are predominantly compounds designed to specifically hit one target with a large effect. The wide array of bioactive compounds in tomatoes have a relative subtle effect on a many cellular targets. Furthermore, the effect of a bioactive compound is not restricted to one target; it often induces a multitude of subtle effects that are delicately spread over different targets of an intricate network of complex processes, such as occurring in the process of inflammation. The subtle effects of phytochemicals might add up to give a substantial beneficial overall health effect. Moreover, different bioactives can interact on the same or inter-connected targets that may result in additive or synergistic interactions which further magnifies their impact. Examples are the effective interaction of lycopene $\beta$-carotene and $\alpha$-tocopherol and the synergistic cooperation between ascorbic acid and $\alpha$-tocopherol in the protection against lipid peroxidation (42-45). 


\subsection{The inflammatory process}

\subsubsection{Activation of the inflammatory process}

Inflammation is a defensive immune response to protect against (external) challenges, such as infections, bacteria and tissue damage. Damage to tissues can occur during physiological reactions when reactive molecules are formed $(46,47)$. For instance, when oxygen is formed in the oxidative phosphorylation, about $2 \%$ of this oxygen is not completely reduced to water, but forms hydrogen peroxide or free radicals. Free radicals are species capable of independent existence that contains one or more unpaired electrons $(48,49)$. The unpaired electron(s) render these molecules to be very reactive.

The partial reduction of oxygen gives rise to reactive oxygen species (ROS), including free radicals and non-radicals. Likewise, reactive nitrogen species (RNS) can be produced (50). Among these reactive species the hydroxyl radical is the most reactive one towards most biological substrates.

ROS and RNS are formed in several physiological conditions to fulfil pivotal physiological functions (51). For instance, the formation of ROS/RNS is key during the immune response in which various phagocytic cells produce hypochlorous acid to kill invading agents $(49,52)$. However, due to their high reactivity, often ROS and RNS production leads to cellular damage.

\subsubsection{Lipid peroxidation}

One of the most studied undesirable effects of ROS is lipid peroxidation $(47,53)$. Lipid peroxidation is an important process in the radical mediated injury to cells. Cells contain a lipid bilayer that contains polyunsaturated fatty acids (PUFA's). PUFA's are prone to oxidation (figure 4). When a hydroxyl radical $\left({ }^{\bullet} \mathrm{OH}\right)$ is generated near membranes, it can abstract a hydrogen atom from a PUFA (54). Consequently, a lipid-radical is formed which undergoes molecular rearrangement. Subsequently, it reacts quickly with oxygen resulting in the formation of a lipid peroxyl radical. These peroxyl radicals are reactive and attack adjacent PUFA by abstracting an $\mathrm{H}$-atom and forming a lipid hydroperoxide. Simultaneously, a new lipid-radical is generated which propagates the chain reaction. Termination of this chain reaction occurs when either PUFA's or oxygen are completely consumed, when a relatively un-reactive radical is formed, or when two radicals combine to form a non-radical pair (53). The products that are formed during this process include 4-hydroxy-2, 3-trans-nonenal (HNE) and malonaldehyde (MDA). These products can be toxic: MDA can damage DNA and cause mutagenic lesions, while HNE inhibits cell division and proliferation $(53,55)$. 

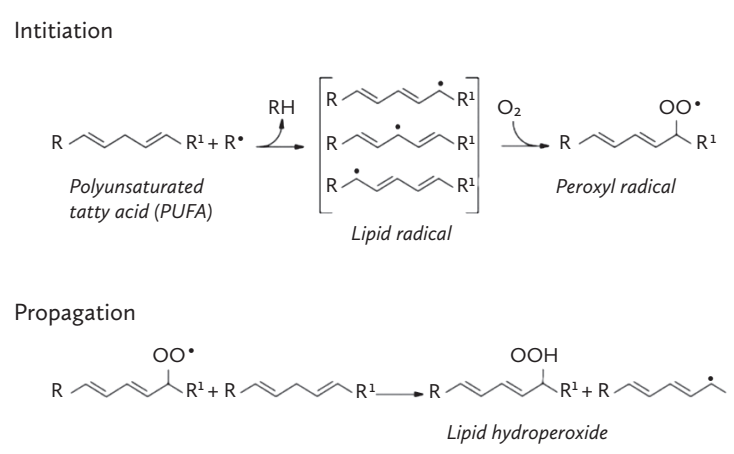

Prone to lipid peroxidation are the transporters of cholesterol and fatty acids, e.g. low density lipoproteins ( $L D L)$. $L D L$ is oxidized when it becomes trapped in the vascular wall of the endothelium (56). Oxidized LDL damages tissues and progressively results in persistent low grade inflammation highly associated with the development of atherosclerosis. In different lines of research the protective effect against LDL oxidation of tomato products and lycopene has been demonstrated, which is summarized in table 1.

\subsubsection{Protein kinase C}

Inflammation is a complex biological system consisting of a series of reactions, including cellsignaling, gene expression, cytokine production and chemotaxis. Chronic inflammation has been related to a variety of pathological conditions, including, atherosclerosis, obesity, diabetes and cancer. In many of the pathways involved activation of protein kinase C (PKC) is a critical step (71-78). PKC is involved in a large variety of cell functions and signal transduction pathways regulating cell migration and polarity, proliferation, differentiation and cell death $(79,80)$. PKC consists of several isoforms that can be divided into 3 major groups based on their structural characteristics and cofactor requirements. These include classical cPKC $(\alpha, \beta I I)$, novel nPKC $(\delta)$ and atypical aPKC isoforms $(73,81)$. All PKC isoforms require phosphatidylserine, a component of the phospholipid bilayer for their activation. Classical PKC's are calcium sensitive and need calcium and diacylglycerol (DAG) or phorbol esters for their activation. nPKC's are calcium independent but still need DAG or phorbol esters to be activated, while the atypical PKC's are calcium independent and do not need DAG or phorbol esters (73). 
Table 1. The beneficial effect of lycopene and tomato based products against lipid peroxidation and LDL oxidation

\begin{tabular}{|c|c|c|c|c|}
\hline \multicolumn{5}{|l|}{ Animal studies } \\
\hline \multirow[t]{2}{*}{ Lycopene dose } & \multirow[t]{2}{*}{ Animals } & \multicolumn{2}{|c|}{ Protection against } & \multirow[t]{2}{*}{ Reference } \\
\hline & & $\angle P O$ & LDLox & \\
\hline $9.3 \mathrm{mg} / \mathrm{loog}$ & Mice & ++ & & (57) \\
\hline $0.01 \mathrm{mg} / \mathrm{d}$ & Rats & ++++ & & (10) \\
\hline $15.8 \mathrm{mg} / \mathrm{d}$ & Pigs & ++++ & & $(58)$ \\
\hline $15 \mathrm{mg} / 100 \mathrm{~g}$ & Rabbits & & + & (59) \\
\hline $0.8 \mathrm{mg} / \log ^{3}$ & Hamsters & $++++^{a}$ & ++++ & $(60)$ \\
\hline
\end{tabular}

\section{Intervention studies (healthy subjects)}

\begin{tabular}{llllll} 
Lycopene dose & \multicolumn{2}{l}{ Subjects } & \multicolumn{2}{l}{ Protection against } & Reference \\
& Age & $n$ & LPO & LDLox & \\
$39-75 \mathrm{mg} / \mathrm{d}$ & $25-40$ & 19 & $++^{\mathrm{b}}$ & ++ & $+61)$ \\
$37 \mathrm{mg} / \mathrm{d}$ & $>60$ & 50 & + & ++ & $(62)$ \\
$23-35 \mathrm{mg} / \mathrm{d}$ & $>40$ & 60 & & ++ & $(63)$ \\
$3.3-12 \mathrm{mg} / \mathrm{d}$ & $22-38$ & 12 & & & $(64)$ \\
$3.3-12 \mathrm{mg} / \mathrm{d}$ & 25 & 12 & $++^{\mathrm{c}}$ & 0 & $(65)$ \\
$37 \mathrm{mg} / \mathrm{d}$ & 29 & 22 & 0 & & $(66)$ \\
$21 \mathrm{mg} / \mathrm{d}$ & $19-27$ & 24 & $+^{\mathrm{d}}$ & & $(67)$
\end{tabular}

\section{Clinical studies (patients)}

\begin{tabular}{llllll} 
Lycopene dose & Clinical status & age & $n$ & \multicolumn{2}{c}{ Protection against Reference } \\
& & & & LPO & LDLox \\
$15 \mathrm{mg} / \mathrm{d}$ & Grade I hypertension & $30-70$ & 31 & ++ & $(68)$ \\
$25 \mathrm{mg} / \mathrm{d}$ & Grade I hypertension & $35-55$ & 40 & $++^{\mathrm{e}}$ & $(69)$ \\
$25 \mathrm{mg} / \mathrm{d}$ & CVD diagnosed & $35-55$ & 40 & $++^{\mathrm{e}}$ & $(70)$
\end{tabular}

Effects presented for lipid peroxidation (LPO) are based on the decreased percentage thiobarbituric acidreacting substances (TBARS; nmol/ml) formation, and for LDL oxidation (LDLox) the increase of lag time (minutes)of conjugated diene formation in isolated LDL after administration of fresh tomatoes ${ }^{1}$, dried tomatoes ${ }^{2}$, tomato paste ${ }^{3}$, tomato extract ${ }^{4}$, tomato juice ${ }^{5}$, tomato soup ${ }^{6}$, tomato sauce or cooked tomatoes $^{8}$. + Corresponds with $0-10 \%,++$ corresponds with $11-25 \%,+++$ corresponds with $26-50 \%$, ++++ corresponds with $51-100 \%$ and o corresponds with no effect.

a TBARS expressed as nmol/malondialdehyde (MDA) equivalents.

b TBARS expressed as $\mathrm{nmol} / \mathrm{mol}$ LDL.

c TBARS expressed as $\mathrm{ng} / \mathrm{mg}$ protein TBARS formation was measured in urine and expressed as $\mathrm{nmol} / \mathrm{mg}$ creatinine.

e Lipid peroxidation was expressed as the rate of MDA formation MDA nmol/h. 
Upon activation, PKC translocates to different cellular components. The specific structure of the PKC isoform determines the interaction with cellular components such as the plasma membrane, Golgi apparatus and cytoskeleton $(78,82,83)$. This particular interaction is important for the functional outcome of the downstream pathway. For instance, CPKC- $\alpha$ and $\beta \mathrm{II}$ are involved in activating inflammatory pathways, while the novel PKC isoform $\delta$ is involved in apoptotic pathways.

Azzi et al. revealed that one of the major tomato constituents, $\alpha$-tocopherol, specifically inactivates PKC- $\alpha$ by modulating its phosphorylation state (84). Up to now, there are no data available on the effect of carotenoids like lycopene, tomatoes and tomato products, respectively on PKC activity. Since PKC has become a promesing molecular target in the search and development of new drugs for the treatment, e.g. vascular complications in obesity and diabetes, it would be worthwhile to investigate the effects of nutritional compounds in tomatoes on PKC activity.

\subsubsection{Cytokine production}

An important inflammatory regulator is the transcription factor nuclear factor kappa B (NFKB) $(85,86)$. NFKB is not only activated by PKC, but also by ROS. The activation of NFKB gives rise to the expression of genes of pro- and anti-inflammatory cytokines and their subsequent production (85). It has been postulated that lycopene extracted from tomatoes inhibits NFKB activation in human macrophages, and in adipose tissue of mice $(39,40)$. Anti-inflammatory cytokines such as IL-10, are produced to control inflammation (87), while pro-inflammatory cytokines including tumor necrosis factor-alpha (TNF- $\alpha$ ), IL- 6 and IL- 8 amplify the inflammatory response $(87,88)$. For example, the production of TNF- $\alpha$ stimulates NFKB activity, IL- 8 stimulates the recruitment and migration of leukocytes, i.e. chemotaxis. Lycopene extracted from tomatoes reduced pro-inflammatory cytokines and stimulated the anti-inflammatory cytokine IL-10 in macrophages and adipocytes $(40,89,90)$.

The reported effect of lycopene supplementation or tomato product consumption in healthy humans on inflammatory biomarkers is not equivocal. Riso et al. indicated that a tomato drink reduced TNF- $\alpha$ production in healthy volunteers (96). The study of Jacob et al. showed a small or no effect after supplementing tomato juice to healthy subjects (67). It should be noted that it is difficult to identify an anti-inflammatory effect in healthy individuals that do not have a (chronic) inflammation. Another hurdle is that the qualitative and quantitative composition of bioactives in tomato products may greatly vary. Moreover on isolated bioactive compounds poorly predict the health effect of mixtures, since all kind of interactions, varying form antagonism to synergy, often take place. 
Table 2. Overview on in vitro studies that measured the effects of lycopene extracted from tomatoes against the release of inflammatory cytokines from different human cell types.

\begin{tabular}{|c|c|c|c|c|c|}
\hline \multicolumn{6}{|l|}{ In vitro studies } \\
\hline \multirow[t]{2}{*}{ Lycopene dose } & \multirow[t]{2}{*}{ Cell type } & \multicolumn{3}{|c|}{ Effect } & \multirow[t]{2}{*}{ Reference } \\
\hline & & $I L-8$ & $T N F-\alpha$ & $I L-10$ & \\
\hline $2 \mu \mathrm{M}$ & Human macrophages & $\downarrow$ & $\downarrow$ & - & (91) \\
\hline $10 \mu \mathrm{M}$ & Human macrophages & $\mathrm{n} / \mathrm{a}$ & - & $\downarrow$ & (92) \\
\hline $0.3-1.7 \mu \mathrm{M}$ & Human endothelial cells & $\mathrm{n} / \mathrm{a}$ & - & $\uparrow$ & (93) \\
\hline $0.25-4 \mu \mathrm{M}$ & Human macrophages & $\mathrm{n} / \mathrm{a}$ & $\uparrow$ & $\downarrow$ & (94) \\
\hline $0.5-2 \mu \mathrm{M}$ & Human macrophages & $\downarrow$ & $\mathrm{n} / \mathrm{a}$ & $\mathrm{n} / \mathrm{a}$ & (39) \\
\hline $0.25 \mu \mathrm{M}$ & Human monocytes & $\mathrm{n} / \mathrm{a}$ & $\downarrow$ & $\mathrm{n} / \mathrm{a}$ & (95) \\
\hline
\end{tabular}

Figure 5. The process of chemotaxis

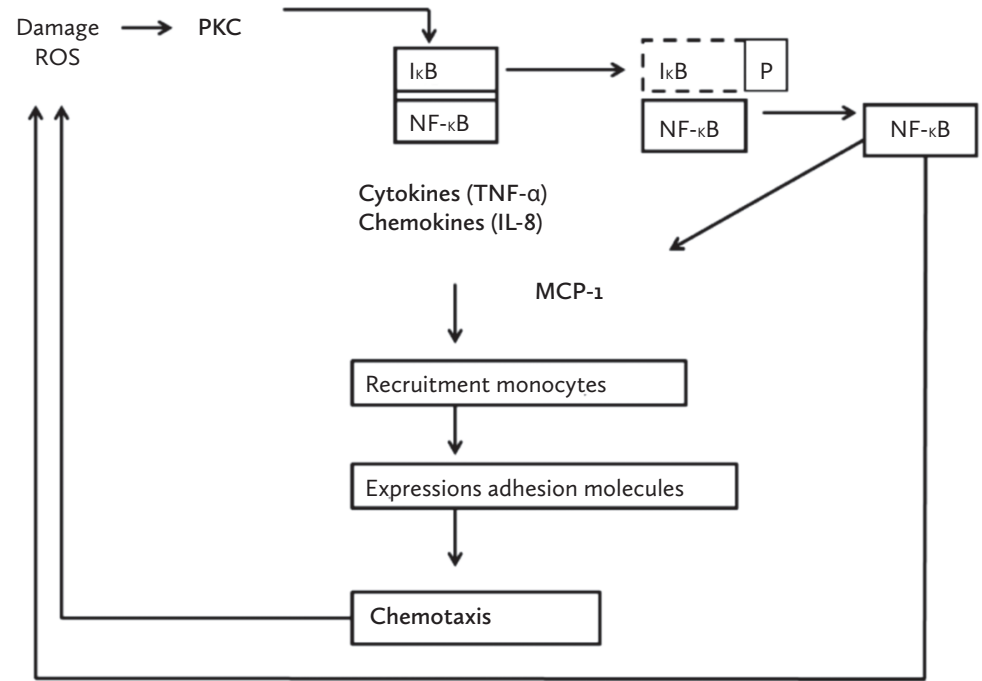

Reactive oxygen species (ROS), protein kinase C (PKC), inhibitor kappa B (IKB), nuclear factor kappa-B (NFKB), tumor necrosis factor-alpha (TNF- $\alpha$ ), monocyte chemotactic protein-1 (MCP-1). 


\subsubsection{Chemotaxis}

Chemotaxis is a process of the rectuitment inflammatory cells to the site of inflammation. During vascular inflammation, the monocytes migrate through the vascular endothelium .The recruitment involves several sequential interactions that consist of an integrated network of inflammatory mediators. The activation of PKC and NFKB and the subsequent formation of pro-inflammatory cytokines are key in chemotaxis. As a result of tissue damage, PKC becomes activated which leads to the activation of NFKB. Subsequently, NFKB stimulates the production of TNF- $\alpha$ and IL-8, cytokines that are involved in the recruitment of monocytes to the inflamed site. Chemotaxis refers to the interaction between the vascular endothelium and monocytes resulting in the migration of monocytes through the endothelium (97, 98). Mono-

cyte recruitment is facilitated by a concentration gradient of chemotactic factors (e.g. IL-8 and monocyte chemotactic protein-1 (MCP-1)) released at the inflamed site by the endothelium (figure 5).

Consequently, the endothelium expresses adhesion molecules (e.g. inter cellular adhesion molecule-1 (ICAM-1), vascular cell adhesion molecule-1 (VCAM-1), E-selecetin), to which monocytes firmly adhere and subsequently migrate through the vascular wall (figure 6) (93, 99). The migration of monocytes into the vascular endothelium is a crucial step in the development of atherosclerosis $(98,100)$. It has been reported that lycopene extracted from tomatoes significantly reduced various chemotaxis related biomarkers, including, IL-8 and ICAM-1 (39, 101, 102). Thus far, there is no data available on the effect of tomato products on markers of chemotaxis.

\subsubsection{Consequences of chronic inflammation}

Persistent low grade inflammation and high levels of ROS contribute to the development of many disorders, such as cardiovascular diseases (CVD), cancer and osteoporosis. CVD including atherosclerosis and hypertension are a major health concern. There is growing evidence that a diet rich in carotenoids i.e. tomatoes protect against CVD $(3,37,38)$. Recently, it was demonstrated that processed tomatoes attenuated LDL oxidation induced by high fat meals in healthy humans (103). Oxidized LDL is a common feature in the development of atherosclerosis and hypertension $(98,104,105)$.

Hypertension is a condition that is often initiated by an increased production of ROS in the endothelium of the vasculature (106). In turn, ROS signal inflammatory mediators such as PKC and NFKB that activate the inflammatory process (107). It is generally accepted that hypertension is associated with an increased risk for myocardial infarction, heart failure and stroke (108). High intake of fruits and vegetables have been related to a decreased blood pressure (109). In fact, lycopene supplementation effectively reduces blood pressure $(33,68,69)$. 
There is limited data on the effects of tomato supplementation on hypertension (110). It was found that $5 \mathrm{wk}$ supplementation with quercetin enriched tomatoes effectively protects the development of hypertension in spontaneously hypertensive rats (unpublished data (111)). Paran and co-workers (33) observed that six weeks supplementation with a tomato extract effectively reduced arterial blood pressure in moderate hypertensive patients with uncontrolled blood pressure. However, it remains worthwhile to shed more light on the anti-hypertensive potential of whole tomatoes or tomato product intake.

Chronic inflammation and high levels of ROS are also a critical component of tumor progression. Many cancers arise from sites of infection, chronic irritation and inflammation (51). Tomatoes have a pronounced potential to attenuate carcinogenesis (3, 112-114). The chemopreventive properties of tomatoes are rendered by the interaction between its bioactive compounds lycopene, phytoene and $\beta$-carotene (115).

Osteoporosis is a bone disease that occurs primarily among post-menopause women (116). Typically, in osteoporotic patients high levels of ROS and persistent low grade inflammation are observed (116). Clinical data have postulated that tomatoes have a beneficial effect to bone health (117). The molecular and cellular mechanisms of tomatoes on osteoporosis are not clear. However, there are some implications that point at the antioxidant activity of tomatoes that might be responsible for the beneficial effects $(118,119)$. 


\subsection{Conclusion}

Tomatoes contain a wide variety of bioactive compounds, among others the carotenoid lycopene and the vitamins ascorbic acid and $\alpha$-tocopherol. In isolation, these bioactives have a protective potential against inflammation. Each bioactive compound has a unique biochemical profile that that is reflected in the diversity of the molecular mechanism involved in their potential health effect. This diversity forms the fundament of the cooperation observed in mixtures of different bioactive compounds and comprises additive as well as synergistic effects on similar and different molecular targets. Due to this interplay, the myriad of subtle effects of various phytochemicals are integrated to produce the observed health effects of tomatoes. Elucidation of the molecular mechanisms involved in activity and interaction of different bioactive compounds in tomatoes is needed to substantiate the health claims. Ultimately, it can be used to optimize the potential health effect. 


\section{References}

1. USDA National Nutrient Database for Standard Reference R. 2008.

2. Lucier G, Scott Kantor L, Allshouse J. Factors affecting tomato consumption in the United States: USDA Economic Research Service; 2000.

3. Canene-Adams K, Campbell JK, Zaripheh S, Jeffery EH, Erdman JW, Jr. The tomato as a functional food. The Journal of nutrition. 2005 May;135:1226-30.

4. Ellinger S, Ellinger J, Stehle P. Tomatoes, tomato products and lycopene in the prevention and treatment of prostate cancer: do we have the evidence from intervention studies? Curr Opin Clin Nutr Metab Care. 2006 Nov;9:722-7.

5. Kavanaugh CJ, Trumbo PR, Ellwood KC. The U.S. Food and Drug Administration's Evidence-Based Review for Qualified Health Claims: Tomatoes, Lycopene, and Cancer. J Natl Cancer Inst. 2007 July 18, 2007;99:1074-85.

6. Re R, Mishra GD, Thane CW, Bates CJ. Tomato consumption and plasma lycopene concentration in people aged $65 \mathrm{y}$ and over in a British national survey. European journal of clinical nutrition. 2003 Dec;57:1545-54.

7. Willcox JK, Catignani GL, Lazarus S. Tomatoes and cardiovascular health. Crit Rev Food Sci Nutr. 2003;43:1-18.

8. Agarwal S, Rao AV. Tomato lycopene and its role in human health and chronic diseases. Cmaj. 2000 Sep 19;163:739-44.

9. Hadley CW, Miller EC, Schwartz SJ, Clinton SK. Tomatoes, Lycopene, and Prostate Cancer: Progress and Promise. 2002. p. 869-80.

10. Das S, Otani H, Maulik N, Das DK. Lycopene, tomatoes, and coronary heart disease. Free radical research. 2005 Apr;39:449-55.

11. Rao AV, Agarwal S. Role of antioxidant lycopene in cancer and heart disease. Journal of the American College of Nutrition. 2000 Oct;19:563-9.

12. Bodannes RS, Chan PC. Ascorbic acid as a scavenger of singlet oxygen. FEBS Letters. 1979;105:195-6.

13. Halliwell B, Wasil M, Grootveld M. Biologically significant scavenging of the myeloperoxidase-derived oxidant hypochlorous acid by ascorbic acid: Implications for antioxidant protection in the inflamed rheumatoid joint. FEBS Letters. 1987;213:15-7.

14. Traber MG, Stevens JF. Vitamins $C$ and E: beneficial effects from a mechanistic perspective. Free radical biology \& medicine. 2011 Sep 1;51:1000-13.

15. Ulrich-Merzenich G, Metzner C, Schiermeyer B, Vetter H. Vitamin C and vitamin E antagonistically modulate human vascular endothelial and smooth muscle cell DNA synthesis and proliferation. European journal of nutrition. 2002 Feb;41:27-34.

16. Toohey JI. Dehydroascorbic acid as an anti-cancer agent. Cancer letters. 2008 May 18;263:164-9.

17. Li Y, Schellhorn HE. New developments and novel therapeutic perspectives for vitamin C. The Journal of nutrition. 2007 Oct;137:2171-84.

18. Bohm F, Settergren M, Pernow J. Vitamin C blocks vascular dysfunction and release of interleukin- 6 induced by endothelin-1 in humans in vivo. Atherosclerosis. 2007 Feb;190:408-15.

19. Rodrigo R, Guichard C, Charles R. Clinical pharmacology and therapeutic use of antioxidant vitamins. Fundam Clin Pharmacol. 2007 Apr;21:111-27. 
20. Azzi A, Breyer I, Feher M, Ricciarelli R, Stocker A, Zimmer S, Zingg J. Nonantioxidant functions of alphatocopherol in smooth muscle cells. The Journal of nutrition. 2001 Feb;131:378S-81S.

21. Murohara T, Ikeda H, Otsuka Y, Aoki M, Haramaki N, Katoh A, Takajo Y, Imaizumi T. Inhibition of platelet adherence to mononuclear cells by alpha-tocopherol: role of P-selectin. Circulation. 2004 Jul 13;110:141-8.

22. van Haaften RI, Haenen GR, Evelo CT, Bast A. Effect of vitamin E on glutathione-dependent enzymes. Drug Metab Rev. 2003 May-Aug;35:215-53.

23. van Haaften RI, Haenen GR, van Bladeren PJ, Bogaards JJ, Evelo CT, Bast A. Inhibition of various glutathione Stransferase isoenzymes by RRR-alpha-tocopherol. Toxicol In Vitro. 2003 Jun;17:245-51.

24. Valastyan S, Thakur V, Johnson A, Kumar K, Manor D. Novel transcriptional activities of vitamin E: inhibition of cholesterol biosynthesis. Biochemistry. 2008 Jan 15;47:744-52.

25. Traber MG, Packer L. Vitamin E: beyond antioxidant function. The American journal of clinical nutrition. 1995 Dec;62:1501S-9S.

26. van Haaften RI, Evelo CT, Haenen GR, Bast A. alpha-Tocopherol inhibits human glutathione S-transferase pi. Biochemical and biophysical research communications. 2001 Jan 26;280:631-3.

27. Ekstrand-Hammarstrom B, Osterlund C, Lilliehook B, Bucht A. Vitamin E down-modulates mitogen-activated protein kinases, nuclear factor-kappaB and inflammatory responses in lung epithelial cells. Clinical and experimental immunology. 2007 Feb;147:359-69.

28. Frusciante L, Carli P, Ercolano MR, Pernice R, Di Matteo A, Fogliano V, Pellegrini N. Antioxidant nutritional quality of tomato. Molecular nutrition \& food research. 2007 May;51:609-17.

29. Boileau TW, Boileau AC, Erdman JW, Jr. Bioavailability of all-trans and cis-isomers of lycopene. Exp Biol Med (Maywood). 2002 Nov;227:914-9.

30. Boileau AC, Merchen NR, Wasson K, Atkinson CA, Erdman JW, Jr. Cis-lycopene is more bioavailable than translycopene in vitro and in vivo in lymph-cannulated ferrets. The Journal of nutrition. 1999 Jun;129:1176-81.

31. Blum A, Merei M, Karem A, Blum N, Ben-Arzi S, Wirsansky I, Khazim K. Effects of tomatoes on the lipid profile. Clinical and investigative medicine. 2006 Oct;29:298-300.

32. Silaste ML, Alfthan G, Aro A, Kesaniemi YA, Horkko S. Tomato juice decreases LDL cholesterol levels and increases LDL resistance to oxidation. Br J Nutr. 2007 Dec;98:1251-8.

33. Paran E, Novack V, Engelhard YN, Hazan-Halevy I. The effects of natural antioxidants from tomato extract in treated but uncontrolled hypertensive patients. Cardiovascular drugs and therapy / sponsored by the International Society of Cardiovascular Pharmacotherapy. 2009 Apr;23:145-51.

34. Voutilainen S, Nurmi T, Mursu J, Rissanen TH. Carotenoids and cardiovascular health. The American journal of clinical nutrition. 2006 Jun;83:1265-71.

35. Ried K, Fakler P. Protective effect of lycopene on serum cholesterol and blood pressure: Meta-analyses of intervention trials. Maturitas. 2011 Apr;68:299-310.

36. Mordente A, Guantario B, Meucci E, Silvestrini A, Lombardi E, Martorana GE, Giardina B, Bohm V. Lycopene and cardiovascular diseases: an update. Curr Med Chem. 2011;18:1146-63.

37. Story EN, Kopec RE, Schwartz SJ, Harris GK. An update on the health effects of tomato lycopene. Annu Rev Food Sci Technol. 2010;1:189-210. 
38. Bohm V. Lycopene and heart health. Molecular nutrition \& food research. 2012 Feb;56:296-303.

39. Simone RE, Russo M, Catalano A, Monego G, Froehlich K, Boehm V, Palozza P. Lycopene inhibits NF-kBmediated IL-8 expression and changes redox and PPARgamma signalling in cigarette smoke-stimulated macrophages. PLoS One. 2011;6:e19652.

40. Gouranton E, Thabuis C, Riollet C, Malezet-Desmoulins C, El Yazidi C, Amiot MJ, Borel P, Landrier JF. Lycopene inhibits proinflammatory cytokine and chemokine expression in adipose tissue. J Nutr Biochem. 2011 Jul;22:642-8.

41. Palozza P, Parrone N, Catalano A, Simone R. Tomato lycopene and inflammatory cascade: basic interactions and clinical implications. Curr Med Chem. 2010;17:2547-63.

42. Heber D, Lu QY. Overview of mechanisms of action of lycopene. Exp Biol Med (Maywood). 2002 Nov;227:920-3.

43. Junghans A, Sies H, Stahl W. Carotenoid-containing unilamellar liposomes loaded with glutathione: a model to study hydrophobic-hydrophilic antioxidant interaction. Free radical research. 2000 Dec;33:801-8.

44. Niki E. Interaction of ascorbate and alpha-tocopherol. Annals of the New York Academy of Sciences. 1987;498:186-99.

45. Niki E, Noguchi N, Tsuchihashi H, Gotoh N. Interaction among vitamin C, vitamin E, and beta-carotene. The American journal of clinical nutrition. 1995 Dec;62:1322S-6S.

46. Barry Halliwell JG. Free Radicals in Biology and Medicine 4 edition ed: Oxford University Press, USA; 2007.

47. Halliwell B. Free radicals, reactive oxygen species and human disease: a critical evaluation with special reference to atherosclerosis. Br J Exp Pathol. 1989 Dec;70:737-57.

48. Halliwell B. Tell me about free radicals, doctor: a review. J R Soc Med. 1989 Dec;82:747-52.

49. Davies KJ. Oxidative stress: the paradox of aerobic life. Biochem Soc Symp. 1995;61:1-31.

50. Halliwell B, Cross CE. Oxygen-derived species: their relation to human disease and environmental stress. Environ Health Perspect. 1994 Dec;102 Suppl 10:5-12.

51. Kundu JK, Surh YJ. Inflammation: gearing the journey to cancer. Mutat Res. 2008 Jul-Aug;659:15-30.

52. Parkin J, Cohen B. An overview of the immune system. The Lancet. 2001;357:1777-89.

53. Halliwell B, Chirico S. Lipid peroxidation: its mechanism, measurement, and significance. Am J Clin Nutr. 1993 May;57:715S-24S; discussion 24S-25S.

54. Tappel AL. Biological antioxidant protection against lipid peroxidation damage. The American journal of clinical nutrition. 1970 Aug;23:1137-9.

55. Thomas SR, Witting PK, Drummond GR. Redox control of endothelial function and dysfunction: molecular mechanisms and therapeutic opportunities. Antioxid Redox Signal. 2008 Oct;10:1713-65.

56. Stocker R, Keaney JF, Jr. Role of oxidative modifications in atherosclerosis. Physiol Rev. 2004 Oct;84:1381-478.

57. Suganuma $\mathrm{H}$, Inakuma T. Protective effect of dietary tomato against endothelial dysfunction in hypercholesterolemic mice. Bioscience, biotechnology, and biochemistry. 1999 Jan;63:78-82.

58. Pajk T, Rezar V, Levart A, Salobir J. Efficiency of apples, strawberries, and tomatoes for reduction of oxidative stress in pigs as a model for humans. Nutrition (Burbank, Los Angeles County, Calif. 2006;22:376-84.

59. Frederiksen H, Rasmussen SE, Schroder M, Bysted A, Jakobsen J, Frandsen H, Ravn-Haren G, Mortensen A. Dietary supplementation with an extract of lycopene-rich tomatoes does not reduce atherosclerosis in Watanabe Heritable Hyperlipidemic rabbits. Br J Nutr. 2007 Jan;97:6-10. 
6o. Hsu YM, Lai $\mathrm{CH}$, Chang $\mathrm{CY}$, Fan $\mathrm{CT}$, Chen $\mathrm{CT}, \mathrm{Wu} \mathrm{CH}$. Characterizing the lipid-lowering effects and antioxidant mechanisms of tomato paste. Bioscience, biotechnology, and biochemistry. 2008 Mar;72:677-85.

61. Agarwal S, Rao AV. Tomato lycopene and low density lipoprotein oxidation: a human dietary intervention study. Lipids. 1998 Oct;33:981-4.

62. Bub A, Barth S, Watzl B, Briviba K, Herbert BM, Luhrmann PM, Neuhauser-Berthold M, Rechkemmer G. Paraoxonase 1 Q192R (PON1-192) polymorphism is associated with reduced lipid peroxidation in R-allele-carrier but not in QQ homozygous elderly subjects on a tomato-rich diet. European journal of nutrition. 2002 Dec;41:237-43.

63. Hadley CW, Clinton SK, Schwartz SJ. The Consumption of Processed Tomato Products Enhances Plasma Lycopene Concentrations in Association with a Reduced Lipoprotein Sensitivity to Oxidative Damage. 2003 March 1, 2003;133:727-32.

64. Visioli F, Riso P, Grande S, Galli C, Porrini M. Protective activity of tomato products on in vivo markers of lipid oxidation. European journal of nutrition. 2003 Aug;42:201-6.

65. Riso P, Visioli F, Erba D, Testolin G, Porrini M. Lycopene and vitamin C concentrations increase in plasma and lymphocytes after tomato intake. Effects on cellular antioxidant protection. European journal of clinical nutrition. 2004 Oct;58:1350-8.

66. Bub A, Barth SW, Watzl B, Briviba K, Rechkemmer G. Paraoxonase 1 Q192R (PON1-192) polymorphism is associated with reduced lipid peroxidation in healthy young men on a low-carotenoid diet supplemented with tomato juice. Br J Nutr. 2005 Mar;93:291-7.

67. Jacob K, Periago MJ, Bohm V, Berruezo GR. Influence of lycopene and vitamin C from tomato juice on biomarkers of oxidative stress and inflammation. Br J Nutr. 2008 Jan;99:137-46.

68. Engelhard YN, Gazer B, Paran E. Natural antioxidants from tomato extract reduce blood pressure in patients with grade-1 hypertension: a double-blind, placebo-controlled pilot study. American heart journal. 2006 Jan;151:100.

69. Bose KS, Agrawal BK. Effect of lycopene from tomatoes (cooked) on plasma antioxidant enzymes, lipid peroxidation rate and lipid profile in grade-I hypertension. Annals of nutrition \& metabolism. 2007;51:477-81.

70. Bose KS, Agrawal BK. Effect of lycopene from cooked tomatoes on serum antioxidant enzymes, lipid peroxidation rate and lipid profile in coronary heart disease. Singapore medical journal. 2007 May;48:415-20.

71. Kawakami Y, Yao L, Tashiro M, Gibson S, Mills GB, Kawakami T. Activation and interaction with protein kinase C of a cytoplasmic tyrosine kinase, Itk/Tsk/Emt, on Fc epsilon RI cross-linking on mast cells. J Immunol. 1995 Oct 1;155:3556-62.

72. Kawakami T, Kawakami Y, Kitaura J. Protein kinase C beta (PKC beta): normal functions and diseases. J Biochem. 2002 Nov;132:677-82.

73. Breitkreutz D, Braiman-Wiksman L, Daum N, Denning MF, Tennenbaum T. Protein kinase C family: on the crossroads of cell signaling in skin and tumor epithelium. J Cancer Res Clin Oncol. 2007 Nov;133:793-808.

74. Barnett ME, Madgwick DK, Takemoto DJ. Protein kinase C as a stress sensor. Cell Signal. 2007 Sep;19:1820-9.

75. Tinsley JH, Hunter FA, Childs EW. PKC and MLCK-dependent, cytokine-induced rat coronary endothelial dysfunction. J Surg Res. 2009 Mar;152:76-83. 
76. Mut M, Amos S, Hussaini IM. PKC alpha phosphorylates cytosolic NF-kappaB/p65 and PKC delta delays nuclear translocation of NF-kappaB/p65 in U1242 glioblastoma cells. Turk Neurosurg. 2010 Jul;20:277-85.

77. Lu X, Bean JS, Kassab GS, Rekhter MD. Protein kinase C inhibition ameliorates functional endothelial insulin resistance and vascular smooth muscle cell hypersensitivity to insulin in diabetic hypertensive rats. Cardiovasc Diabetol. 2011;10:48.

78. Diaz-Meco MT, Moscat J. The atypical PKCs in inflammation: NF-kappaB and beyond. Immunol Rev. 2012 Mar;246:154-67.

79. Nishizuka Y. Protein kinase C and lipid signaling for sustained cellular responses. Faseb J. 1995 Apr;9:484-96.

80. Nishizuka Y, Nakamura S. Lipid mediators and protein kinase $C$ for intracellular signalling. Clin Exp Pharmacol Physiol Suppl. 1995 Dec;22:S202-3.

81. Yamaguchi K, Ogita K, Nakamura S, Nishizuka Y. The protein kinase $C$ isoforms leading to MAP-kinase activation in $\mathrm{CHO}$ cells. Biochemical and biophysical research communications. 1995 May 25;210:639-47.

82. Zeng L, Webster SV, Newton PM. The biology of protein kinase C. Advances in experimental medicine and biology. 2012;740:639-61.

83. Sobhia ME, Grewal BK, Bhat J, Rohit S, Punia V. Protein kinase $C$ betall in diabetic complications: survey of structural, biological and computational studies. Expert Opin Ther Targets. 2012 Mar;16:325-44.

84. Ricciarelli R, Tasinato A, Clement S, Ozer NK, Boscoboinik D, Azzi A. alpha-Tocopherol specifically inactivates cellular protein kinase $\mathrm{C}$ alpha by changing its phosphorylation state. The Biochemical journal. 1998 Aug 15;334 ( Pt 1):243-9.

85. Hayden MS, West AP, Ghosh S. NF-kappaB and the immune response. Oncogene. 2006 Oct 30;25:6758-80.

86. Ghosh S, Hayden MS. New regulators of NF-kappaB in inflammation. Nat Rev Immunol. 2008 Nov;8:837-48.

87. Galkina E, Ley K. Immune and inflammatory mechanisms of atherosclerosis (*). Annu Rev Immunol. 2009;27:165-97.

88. Parkin J, Cohen B. An overview of the immune system. Lancet. 2001 Jun 2;357:1777-89.

89. Feng D, Ling WH, Duan RD. Lycopene suppresses LPS-induced NO and IL-6 production by inhibiting the activation of ERK, P38MAPK, and NF-kappaB in macrophages. Inflamm Res. 2010 Feb;59:115-21.

9o. Hung CF, Huang TF, Chen BH, Shieh JM, Wu PH, Wu WB. Lycopene inhibits TNF-alpha-induced endothelial ICAM-1 expression and monocyte-endothelial adhesion. Eur J Pharmacol. 2008 May 31;586:275-82.

91. Palozza P, Simone R, Catalano A, Boninsegna A, Bohm V, Frohlich K, Mele MC, Monego G, Ranelletti FO. Lycopene prevents 7-ketocholesterol-induced oxidative stress, cell cycle arrest and apoptosis in human macrophages. J Nutr Biochem. 2010 Jan;21:34-46.

92. Napolitano M, De Pascale C, Wheeler-Jones C, Botham KM, Bravo E. Effects of lycopene on the induction of foam cell formation by modified LDL. Am J Physiol Endocrinol Metab. 2007 Dec;293:E1820-7.

93. Martin KR, Wu D, Meydani M. The effect of carotenoids on the expression of cell surface adhesion molecules and binding of monocytes to human aortic endothelial cells. Atherosclerosis. 2000 Jun;150:265-74.

94. Bessler H, Salman H, Bergman M, Alcalay Y, Djaldetti M. <i>In Vitro</i> Effect of Lycopene on Cytokine Production by Human Peripheral Blood Mononuclear Cells. Immunological Investigations. 2008;37:183 - 90.

95. Bergman M, Djaldetti M, Salman H, Bessler H. On the combined effect of statins and lycopene on cytokine production by human peripheral blood cells. Heart Vessels. 2010 Sep;25:426-31. 
96. Riso P, Visioli F, Grande S, Guarnieri S, Gardana C, Simonetti P, Porrini M. Effect of a tomato-based drink on markers of inflammation, immunomodulation, and oxidative stress. J Agric Food Chem. 2006 Apr 5;54:2563-6.

97. Wong $\mathrm{CH}$, Heit $\mathrm{B}$, Kubes P. Molecular regulators of leucocyte chemotaxis during inflammation. Cardiovasc Res. 2010 May 1;86:183-91.

98. Zernecke A, Weber C. Chemokines in the vascular inflammatory response of atherosclerosis. Cardiovasc Res. 2010 May 1;86:192-201.

99. Martin J, Collot-Teixeira S, McGregor L, McGregor JL. The dialogue between endothelial cells and monocytes/macrophages in vascular syndromes. Curr Pharm Des. 2007;13:1751-9.

100. Soehnlein O, Lindbom L, Weber C. Mechanisms underlying neutrophil-mediated monocyte recruitment. Blood. 2009 Nov 19;114:4613-23.

101. Hung C-F, Huang T-F, Chen B-H, Shieh J-M, Wu P-H, Wu W-B. Lycopene inhibits TNF-[alpha]-induced endothelial ICAM-1 expression and monocyte-endothelial adhesion. European Journal of Pharmacology. 2008;586:275-82.

102. Palozza P, Simone R, Catalano A, Monego G, Barini A, Mele MC, Parrone N, Trombino S, Picci N, Ranelletti FO. Lycopene prevention of oxysterol-induced proinflammatory cytokine cascade in human macrophages: inhibition of NF-kappaB nuclear binding and increase in PPARgamma expression. J Nutr Biochem. 2011 Mar;22:259-68.

103. Burton-Freeman B, Talbot J, Park E, Krishnankutty S, Edirisinghe I. Protective activity of processed tomato products on postprandial oxidation and inflammation: A clinical trial in healthy weight men and women. Molecular nutrition \& food research. 2012 Apr;56:622-31.

104. Madamanchi NR, Vendrov A, Runge MS. Oxidative stress and vascular disease. Arteriosclerosis, thrombosis, and vascular biology. 2005 Jan;25:29-38.

105. Spiteller G. The relation of lipid peroxidation processes with atherogenesis: a new theory on atherogenesis. Molecular nutrition \& food research. 2005 Nov;49:999-1013.

106. Puddu P, Puddu GM, Cravero E, Rosati M, Muscari A. The molecular sources of reactive oxygen species in hypertension. Blood Pressure. 2008;17:70 - 7.

107. Alexander RW. Hypertension and the Pathogenesis of Atherosclerosis : Oxidative Stress and the Mediation of Arterial Inflammatory Response: A New Perspective. 1995 February 1, 1995;25:155-61.

108. Vaziri N. Causal link between oxidative stress, inflammation and hypertension Iranian Journal of Kidney Diseases. 2008 January 2008;2:10.

109. Weseler AR, Bast A. Oxidative stress and vascular function: implications for pharmacologic treatments. Curr Hypertens Rep. 2010 Jun;12:154-61.

110. de Leeuw PW, Bast A. Tomato extract for hypertension? Editorial to "The effects of natural antioxidants from tomato extract in treated but uncontrolled hypertensive patients" by E. Paran et al. Cardiovascular drugs and therapy / sponsored by the International Society of Cardiovascular Pharmacotherapy. 2009 Apr;23:107-8.

111. C.G.M. Heijnen GRMMH, A. Bast. The effect of flavonol-enriched tomato paste on blood pressure in sponteneously hypertensive rats. Maastricht; 2001.

112. Palozza P, Parrone N, Simone R, Catalano A. Role of lycopene in the control of ROS-mediated cell growth: implications in cancer prevention. Curr Med Chem. 2011;18:1846-60. 
113. Tan HL, Thomas-Ahner JM, Grainger EM, Wan L, Francis DM, Schwartz SJ, Erdman JW, Jr., Clinton SK. Tomato-based food products for prostate cancer prevention: what have we learned? Cancer Metastasis Rev. 2010 Sep;29:553-68.

114. Canene-Adams K, Lindshield BL, Wang S, Jeffery EH, Clinton SK, Erdman JW, Jr. Combinations of tomato and broccoli enhance antitumor activity in dunning r3327-h prostate adenocarcinomas. Cancer Res. 2007 Jan $15 ; 67: 836-43$.

115. Campbell JK, Engelmann NJ, Lila MA, Erdman JW, Jr. Phytoene, Phytofluene, and Lycopene from Tomato Powder Differentially Accumulate in Tissues of Male Fisher 344 Rats. Nutr Res. 2007 Dec;27:794-801.

116. Palaniswamy C, Selvaraj DR, Rao V, Patel U. Newer therapies for osteoporosis. Am J Ther. 2010 Mar-Apr;17:197-200.

117. Rao LG, Mackinnon ES, Josse RG, Murray TM, Strauss A, Rao AV. Lycopene consumption decreases oxidative stress and bone resorption markers in postmenopausal women. Osteoporos Int. 2007 Jan;18:109-15.

118. Mackinnon ES, Rao AV, Rao LG. Dietary restriction of lycopene for a period of one month resulted in significantly increased biomarkers of oxidative stress and bone resorption in postmenopausal women. J Nutr Health Aging. 2011 Feb;15:133-8.

119. Mackinnon ES, Rao AV, Josse RG, Rao LG. Supplementation with the antioxidant lycopene significantly decreases oxidative stress parameters and the bone resorption marker $\mathrm{N}$-telopeptide of type I collagen in postmenopausal women. Osteoporos Int. 2011 Apr;22:1091-101. 
Knowing others is wisdom;

Knowing the selfis enlighterment.

Mastering others requires force;

Mostering the self requires strength;

He who knows he has enough is rich.

Perseverance is a sign of will power. 

The anti-inflammatory effect of lycopene complements the antioxidant action of ascorbic acid and $\alpha$-tocopherol

Merel Hazewindus

Guido R.M.M. Haenen

Antje R. Weseler

Aalt Bast 


\begin{abstract}
Tomato foods contain bioactive compounds, such as lycopene, ascorbic acid and $\alpha$-tocopherol, which are assumed to show synergistic effects. The aim of the study was to investigate this presumed synergy. The effect on lipid peroxidation and inflammation was assessed. Lipid peroxidation was effectively inhibited by combinations of the compounds compared to the single compounds. Synergy between the combination of ascorbic acid and $\alpha$-tocopherol was confirmed. Lycopene on its own effectively reduced inflammation by inhibiting the release of TNF- $\alpha$ and stimulating IL-10 production. The combination of lycopene, ascorbic acid and $\alpha$ tocopherol tended to display a synergistic interaction on IL-10 production. Our observations highlight that lycopene mitigates inflammation, whereas ascorbic acid and $\alpha$-tocopherol efficiently protect against lipid peroxidation. Both activities are complementary since they diminish the process of inflammation differently on different levels. In relation to health, this is an added value of fruit and vegetables such as tomato products that contain complementary bio-active compounds.
\end{abstract}

\title{
Keywords
}

Tomato, lycopene, inflammation, synergy, complementary, ascorbic acid, alpha-tocopherol 


\subsection{Introduction}

It is generally known that consumption of tomatoes and tomato products are healthy. Clinical studies have shown that a tomato-rich diet decreases the incidence of chronic inflammatory related diseases, such as coronary heart disease and certain types of cancers (1-5). Chronic inflammation is a complex biological process, involving different pathophysiological processes such as radical formation and cytokine production $(6,7)$. Tomato foods contain bioactive compounds that have a protective effect against inflammation (8-10). The most abundant compounds in tomatoes are lycopene, ascorbic acid and $\alpha$-tocopherol (11). It has been observed that lycopene, ascorbic acid and $\alpha$-tocopherol in isolation, inhibit the inflammatory cascade in cultured cells (12-14). Evidence is accumulating that these compounds also show synergistic effects. Together these compounds form an intricate network that is suggested to be responsible for the observed health effects (15-18). A well known example is the synergistic interaction between ascorbic acid and $\alpha$-tocopherol during the process of lipid peroxidation (19). An interplay of bioactive compounds in other biological processes, for instance inflammation, has not been demonstrated. For example, research on the interaction between the prominent compounds in tomatoes is lacking. This prompted us to determine the effect of the main constituents in tomatoes, lycopene, ascorbic acid and $\alpha$-tocopherol on inflammation, with the central focus on their synergy. 


\subsection{Materials and Methods}

\subsubsection{Chemicals}

L- $\alpha$-phosphatidylcholine, ascorbic acid, $\alpha$-tocopherol, 2-thiobarbituric acid (TBA), trichloroacetic acid (TCA), hydrochloric acid $(\mathrm{HCl})$, butylated hydroxytoluene $(\mathrm{BHT})$, ethanol, bovine serum albumin (BSA) and lipopolysaccharide (LPS; Escherichia coli 0.26:B6) were purchased from Sigma Chemical Co. (St. Louis, MO, USA). Lycopene was supplied by Extrasynthese (Lyon Nord, France). RPMI-1640 medium containing L-glutamine was obtained from Gibco (Paisley, United Kingdom). Human TNF- $\alpha$ (7300 pg/mL) and human IL-10 $(4000 \mathrm{pg} / \mathrm{mL})$ were acquired from CLB/Sanquin (Amsterdam, The Netherlands). 2,2'-Azobis (2,4-dimehylvaleronitrile (AMVN) was purchased from Cayman Chemical Company (Michigan, USA). All other chemicals were of analytical grade.

\subsubsection{Lipid peroxidation}

\section{Liposome preparation and incubation}

Liposome preparations were prepared in the dark. Appropriate amounts of $L$ - $\alpha$-phosphatidylcholine, lycopene and $\alpha$-tocopherol were dissolved in chloroform and the desired volume was transferred to a glass test tube and evaporated under a nitrogen stream until a thin film of lipids remained. The lipid film was dissolved in sodium phosphate buffer (PBS; 10omM; $\mathrm{pH} 7.4$ ) to obtain a final concentration of $7.5 \mathrm{mg}$ phospholipid/ml, and passed through a polycarbonate membrane with $2 \mu \mathrm{M}$ pore size (Anotop, Whatman). $50 \mu \mathrm{M}$ Ascorbic acid, dissolved in PBS, was added to the liposomes and the incubation mixture was kept in the dark in a water bath $\left(37^{\circ} \mathrm{C}\right)$ under constant shaking for $45 \mathrm{~min}$. Lipid peroxidation was initiated by 10mM AMVN dissolved in ethanol; the final concentration of ethanol in the incubation mixture was $1 \%$.

\section{Measurement of thiobarbituric acid-reactive substances (TBARS)}

Lipid peroxidation products were measured by the thiobarbituric acid (TBA) assay (Haenen en Bast 1983), with minor modifications. 0.1\% BHT was added to the samples before boiling to prevent formation of TBA-reactive products. The absorbance of the TBA complex was measured at $535 \mathrm{~nm}$ and $600 \mathrm{~nm}$ against a blank that contained all the reagents except the sample. A calibration curve was made to calculate the quantity malondialdehyde (MDA) $\mathrm{nmol} / \mathrm{mg}$ phospholipid in the samples. None of the tested compounds interfered with the absorbance of the TBA assay (data not shown). 


\subsubsection{Whole blood cytokine production assay}

\section{Preparation of the antioxidants}

Lycopene and $\alpha$-tocopherol were dissolved in tetrahydrofuran (THF) and diluted in BSA to obtain a final concentration of $0.04 \%$ THF. Final concentrations of lycopene and $\alpha$-tocopherol as single compounds were $1 \mu \mathrm{M}$ and $0.1 \mu \mathrm{M}$ respectively. Ascorbic acid was dissolved PBS to obtain a final concentration of $50 \mu \mathrm{M}$.

\section{Whole blood assay}

The whole blood assay was performed according to the method of Swennen et al. (20), with minor modifications. The advantage is that the utilized whole blood model closely resembles the in vivo situation and forms an appropriate and reproducible culture condition to measure cytokine production ex vivo. In diluted whole blood, the natural cell-to-cell interactions are preserved and all blood components are present in in vivo ratios. Therefore, this system is a good reflection of the physiological condition (21). Freshly collected blood was aliquoted in 24-well sterile plates and diluted 1:4 with RPMI 1640 (supplemented with L-glutamine). Appropriate amounts of antioxidants to the whole blood were added and incubated in the dark. To induce cytokine production LPS (1ong/ml) was added to the whole blood. The plates were incubated in $5 \% \mathrm{CO}_{2}$ at $37^{\circ} \mathrm{C}$ for $6 \mathrm{~h}$. Cell-free supernatant were collected by centrifugation (600o rpm, 10min at $4^{\circ} \mathrm{C}$ ) and stored at $-20^{\circ} \mathrm{C}$ until further quantification of cytokine (TNF$\alpha$ and IL-10) concentration.

\section{Enzyme linked immune sorbent assay (ELISA)}

All cytokines were quantified using PeliKine Compact human ELISA kits (CLB/Sanquin, The Netherlands) in accordance with the manufacturer's instructions. Cytokine production was related to that of the control incubation without antioxidants. The interference of lycopene, BSA and THF were analysed before the assay was performed and did not show any influence on the in-vitro LPS-induced cytokine production (data not shown).

\subsubsection{Statistics}

The effect of antioxidants (either alone or in combination) on lipid peroxidation and cytokine production were compared to the control samples (containing no antioxidants) and the mixture containing lycopene, ascorbic acid and $\alpha$-tocopherol by using one-way ANOVA corrected with the Bonferroni test. The Mann-Whitney $U$ test was used for samples which were not normally distributed. Two-tailed $P$ values of 0.05 or less were considered statistically significant. All statistical analyses were performed with SPSS 15.0 for windows. Results are reported as mean \pm SEM. 


\subsection{Results}

\subsubsection{Lipid peroxidation}

Lycopene, ascorbic acid and $\alpha$-tocopherol, in isolation, induced a lag time in the onset of lipid peroxidation in liposomes (figure 1). Lycopene was less potent compared to ascorbic acid and $\alpha$-tocopherol. Any combination was more effective than the isolated compounds, except for the combination of lycopene and $\alpha$-tocopherol. Also in the combination, the role of lycopene as an antioxidant appeared to be limited. In agreement with other studies, the combination of ascorbic acid and $\alpha$-tocopherol clearly showed a synergistic interaction.

44

\subsubsection{Inflammation}

Ascorbic acid and $\alpha$-tocopherol neither in isolation nor as combination, did not inhibit inflammation. In fact, these compounds displayed a pro-inflammatory effect evidenced by the increased TNF- $\alpha$ production. Lycopene on its own effectively reduced inflammation and inhibited the production of TNF- $\alpha$ (figure 2).

Neither ascorbic acid nor $\alpha$-tocopherol potentiated or reduced the anti-inflammatory effect of lycopene on TNF- $\alpha$ production. Lycopene in isolation stimulated the release of the antiinflammatory cytokine IL-10 (figure 3).

IL-10 release effectively increased by any combination that contained lycopene. Moreover, the combination of lycopene, ascorbic acid and $\alpha$-tocopherol tended to display a synergistic interaction on IL-10. 


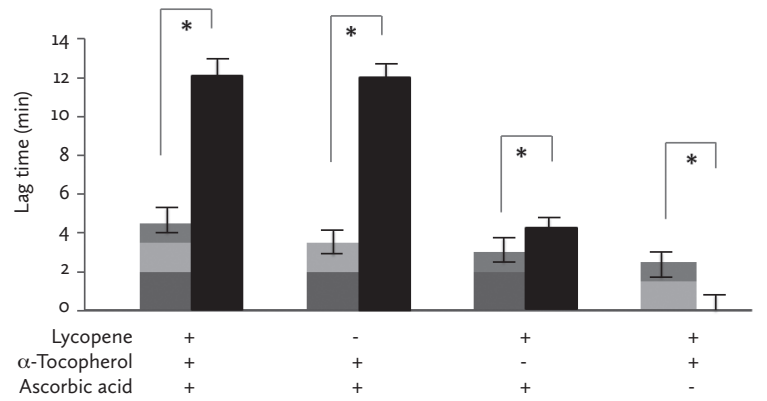

The lag time of lycopene $(1 \mu \mathrm{M})$, ascorbic acid $(50 \mu \mathrm{M})$ and $\alpha$-tocopherol $(0.1 \mu \mathrm{M})$ as separate compounds and in combinations on lipid peroxidation induced by AMVN in liposomes. Results are presented as mean values and SEM of eight triplicate experiments. Tri-colored bars represent the protection by the separate compounds which were summed. The black bars represent the protection by the combinations of compounds. * Significant effect between the sum of the lag time induced by the compounds tested in isolation compared to the lag time induced by the combination $(\mathrm{P} \leq 0.01)$.

Figure 2

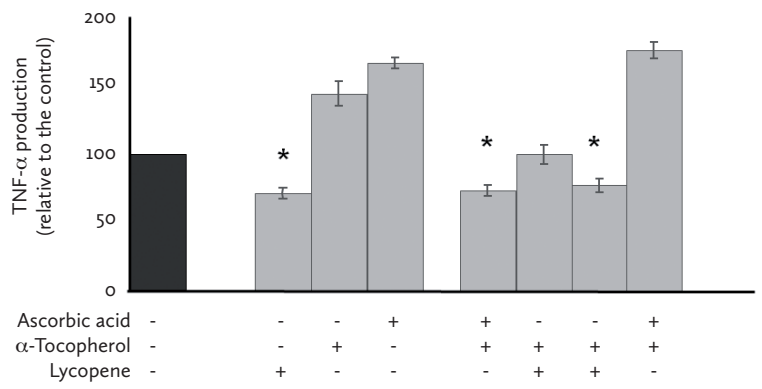

The effect of lycopene $(1 \mu \mathrm{M})$, ascorbic acid $(50 \mu \mathrm{M})$ and $\alpha$-tocopherol $(0.1 \mu \mathrm{M})$ as separate compounds and in combinations on LPS induced TNF- $\alpha$ production in human plasma after 6 hours. Data are presented as mean \pm SEM of 4 triplicates and related to the control (LPS only); * significantly lower than the control P $\leq 0.05$.

Figure 3

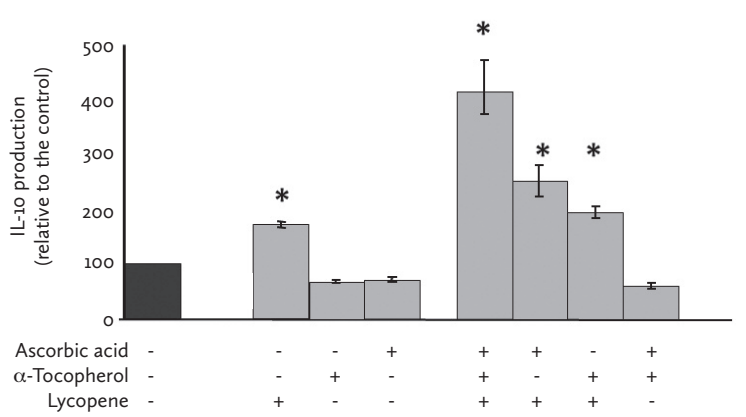

The effect of lycopene $(1 \mu \mathrm{M})$, ascorbic acid $(50 \mu \mathrm{M})$ and $\alpha$-tocopherol $(0.1 \mu \mathrm{M})$ as separate compounds and in combinations on LPS induced IL-10 production in human blood after 6 hours. Data are presented as mean \pm SEM of 4 triplicates and related to the control (LPS only); * significantly higher than the control P $\leq 0.05$. 


\subsection{Discussion}

The inflammatory response is a multifaceted biological process involving for instance the formation of reactive oxygen species (ROS), the production of pro- and anti- inflammatory cytokines, and up-regulation of transcription factors and adhesion molecules $(6,7)$. For example, ROS production results in the process of lipid peroxidation. Consequently, this process initiates the inflammation process which in turn produces ROS (figure 4). ROS also directly activates the inflammatory response through activating pro-inflammatory transcription factors. If lipid peroxidation and inflammation are not properly restrained by physiological self-limiting systems, chronic inflammation is the result.

Bioactive compounds can block inflammatory signaling cascades on different levels, i.e. indirectly by compounds that inhibit lipid peroxidation or directly by compounds that act on proinflammatory transcription factors (6). The different actions of these compounds interrupt the self-amplification of the inflammation process.

In this study, lipid peroxidation was effectively inhibited by the combination of ascorbic acid and $\alpha$-tocopherol. The observed synergistic cooperation is caused by the well documented direct chemical interaction between these compounds. During lipid peroxidation, $\alpha$-tocopherol scavenges free radicals, that are produced within the lipid membrane, and is oxidized to produce the $\alpha$-tocopheroxyl radical (22). The $\alpha$-tocopheroxyl radical is scavenged by ascorbic acid which serves as a radical sink in the water phase. The direct chemical reaction between ascorbic acid and $\alpha$-tocopherol in which electrons are transferred from one molecule to the other, is responsible for the synergy (18).

As in lipid peroxidation, synergy between compounds was also observed during inhibition of the inflammation process (figure 3). However, a direct interaction between inhibitors as in lipid peroxidation is not feasible during inflammation. Chemical transfer of electrons between compounds does not occur during the inflammatory response. Bioactive compounds inhibit inflammation mainly by modifying inflammatory signaling cascades or inflammatory transcription factors (23-25). Therefore, interactions between compounds during inflammation will not be as direct as those observed during lipid peroxidation. In the present study, lycopene effectively stimulated the anti-inflammatory cytokine IL-10 and inhibited the release of the pro-inflammatory cytokine TNF- $\alpha$. It has been observed that lycopene inhibits the production of pro-inflammatory cytokines by reducing the activation of nuclear factor- kappa B (NF-KB), an important transcription factor involved in the inflammation (26). Our observations highlight that lycopene is a compound that mitigates inflammation; the anti-inflammatory effects of lycopene exceed its antioxidant potential. Interestingly, clinical studies demonstrated that 


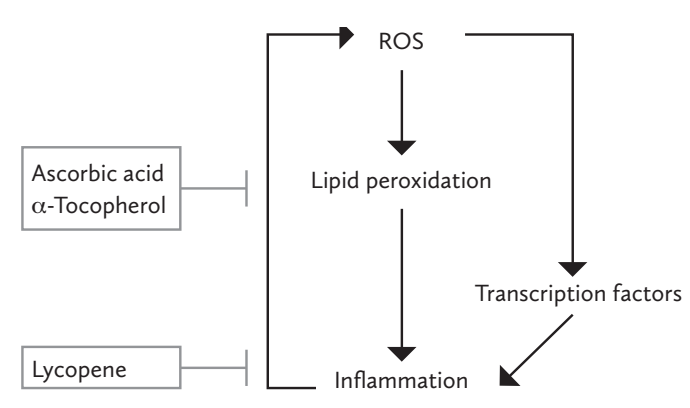

ROS can cause lipid peroxidation, and when this process is not inhibited, the ROS production continues and can initiate the inflammation process. ROS can also directly activate inflammation by stimulating inflammatory transcription factors. During inflammation ROS are as well produced. These ROS promote further amplification of the multi-faceted process. This process is interrupted by a combination of lycopene, ascorbic acid and $\alpha$-tocopherol. These bioactive compounds have complementary activities that mitigates the inflammatory process in a different way on a different level. Lycopene blocks the inflammation process, and the combination of ascorbic acid and $\alpha$-tocopherol block lipid peroxidation.

the anti-inflammatory effect of tomato products are superior to that of lycopene as a single compound (27-30).

The combination of ascorbic acid and $\alpha$-tocopherol which efficiently protects against lipid peroxidation, is complementary to the anti-inflammatory effect of lycopene (figure 4). Because these compounds act on different levels within the inflammation process, the protective potential against inflammation is amplified. The resultant is a synergistic effect of these compounds at a higher integrated level. In relation to health, this is an added value of fruit and vegetables such as tomato products that contain complementary bio-active compounds. 


\section{References}

1. Rao AV, Agarwal S. Role of antioxidant lycopene in cancer and heart disease. J Am Coll Nutr. 200o Oct;19:563-9.

2. Wang L, Liu S, Manson JE, Gaziano JM, Buring JE, Sesso HD. The consumption of lycopene and tomato-based food products is not associated with the risk of type 2 diabetes in women. J Nutr. 2006 Mar;136:620-5.

3. Sesso HD, Liu S, Gaziano JM, Buring JE. Dietary lycopene, tomato-based food products and cardiovascular disease in women. J Nutr. 2003 Jul;133:2336-41.

4. Canene-Adams K, Campbell JK, Zaripheh S, Jeffery EH, Erdman JW, Jr. The tomato as a functional food. J Nutr. 2005 May;135:1226-30.

5. Gomez-Romero M, Arraez-Roman D, Segura-Carretero A, Fernandez-Gutierrez A. Analytical determination of antioxidants in tomato: typical components of the Mediterranean diet. J Sep Sci. 2007 Mar;30:452-61.

6. Conner EM, Grisham MB. Inflammation, free radicals, and antioxidants. Nutrition. 1996 Apr;12:274-7.

7. Kundu JK, Surh YJ. Inflammation: gearing the journey to cancer. Mutation research. 2008 Jul-Aug;659:15-30.

8. Markovits N, Ben Amotz A, Levy Y. The effect of tomato-derived lycopene on low carotenoids and enhanced systemic inflammation and oxidation in severe obesity. Isr Med Assoc J. 2009 Oct;11:598-601.

9. Jacob K, Periago MJ, Bohm V, Berruezo GR. Influence of lycopene and vitamin C from tomato juice on biomarkers of oxidative stress and inflammation. Br J Nutr. 2008 Jan;99:137-46.

10. Singh U, Devaraj S, Jialal I. Vitamin E, oxidative stress, and inflammation. Annu Rev Nutr. 2005;25:151-74.

11. Frusciante L, Carli P, Ercolano MR, Pernice R, Di Matteo A, Fogliano V, Pellegrini N. Antioxidant nutritional quality of tomato. Molecular nutrition \& food research. 2007 May;51:609-17.

12. Crispen PL, Uzzo RG, Golovine K, Makhov P, Pollack A, Horwitz EM, Greenberg RE, Kolenko VM. Vitamin E succinate inhibits NF-kappaB and prevents the development of a metastatic phenotype in prostate cancer cells: implications for chemoprevention. Prostate. 2007 May 1;67:582-90.

13. Feng D, Ling WH, Duan RD. Lycopene suppresses LPS-induced NO and IL-6 production by inhibiting the activation of ERK, P38MAPK, and NF-kappaB in macrophages. Inflamm Res. Feb;59:115-21.

14. Saeed RW, Peng T, Metz CN. Ascorbic acid blocks the growth inhibitory effect of tumor necrosis factor-alpha on endothelial cells. Exp Biol Med (Maywood). 2003 Jul;228:855-65.

15. Trombino S, Serini S, Di Nicuolo F, Celleno L, Ando S, Picci N, Calviello G, Palozza P. Antioxidant effect of ferulic acid in isolated membranes and intact cells: synergistic interactions with alpha-tocopherol, beta-carotene, and ascorbic acid. J Agric Food Chem. 2004 Apr 21;52:2411-20.

16. Thomas CE, McLean LR, Parker RA, Ohlweiler DF. Ascorbate and phenolic antioxidant interactions in prevention of liposomal oxidation. Lipids. 1992 Jul;27:543-50.

17. Niki E, Noguchi N, Tsuchihashi H, Gotoh N. Interaction among vitamin C, vitamin E, and beta-carotene. The American journal of clinical nutrition. 1995 Dec;62:1322S-6S.

18. Niki E. Interaction of ascorbate and alpha-tocopherol. Annals of the New York Academy of Sciences. 1987;498:186-99.

19. Packer L. Protective role of vitamin E in biological systems. The American journal of clinical nutrition. 1991 Apr;53:1050S-5S. 
20. Swennen EL, Bast A, Dagnelie PC. Immunoregulatory effects of adenosine 5'-triphosphate on cytokine release from stimulated whole blood. European journal of immunology. 2005 Mar;35:852-8.

21. Yaqoob P, Newsholme EA, Calder PC. Comparison of cytokine production in cultures of whole human blood and purified mononuclear cells. Cytokine. 1999 Aug;11:600-5.

22. Packer JE, Slater TF, Willson RL. Direct observation of a free radical interaction between vitamin $\mathrm{E}$ and vitamin $\mathrm{C}$. Nature. 1979 Apr 19;278:737-8.

23. Kim GY, Kim JH, Ahn SC, Lee HJ, Moon DO, Lee CM, Park YM. Lycopene suppresses the lipopolysaccharideinduced phenotypic and functional maturation of murine dendritic cells through inhibition of mitogen-activated protein kinases and nuclear factor-kappaB. Immunology. 2004 Oct;113:203-11.

24. Neuzil J, Weber C, Kontush A. The role of vitamin E in atherogenesis: linking the chemical, biological and clinical aspects of the disease. Atherosclerosis. 2001 Aug;157:257-83.

25. Joo YE, Karrasch T, Muhlbauer M, Allard B, Narula A, Herfarth HH, Jobin C. Tomato lycopene extract prevents lipopolysaccharide-induced NF-kappaB signaling but worsens dextran sulfate sodium-induced colitis in NFkappaBEGFP mice. PLoS One. 2009;4:e4562.

26. Gouranton E, Thabuis C, Riollet C, Malezet-Desmoulins C, El Yazidi C, Amiot MJ, Borel P, Landrier JF. Lycopene inhibits proinflammatory cytokine and chemokine expression in adipose tissue. The Journal of nutritional biochemistry. 2010 Oct 15 .

27. Riso P, Visioli F, Grande S, Guarnieri S, Gardana C, Simonetti P, Porrini M. Effect of a tomato-based drink on markers of inflammation, immunomodulation, and oxidative stress. J Agric Food Chem. 2006 Apr 5;54:2563-6.

28. Visioli F, Riso P, Grande S, Galli C, Porrini M. Protective activity of tomato products on in vivo markers of lipid oxidation. European journal of nutrition. 2003 Aug;42:201-6.

29. Upritchard JE, Sutherland WH, Mann JI. Effect of supplementation with tomato juice, vitamin E, and vitamin C on LDL oxidation and products of inflammatory activity in type 2 diabetes. Diabetes Care. 2000 Jun;23:733-8.

30. Fuhrman B, Volkova N, Rosenblat M, Aviram M. Lycopene synergistically inhibits LDL oxidation in combination with vitamin E, glabridin, rosmarinic acid, carnosic acid, or garlic. Antioxid Redox Signal. 2000 Fall;2:491-506. 
$n$
$I$
$D$
0
-1
$m$
0
$w$
$w$ 
Vunde gurunom coronorovinde Sondorsito srotmo subhorsbodhe Nithsreyose jongaliksyomone Sonsora halohola moho santyoi Holo holo

Ahohu purusaleoram sonkho colerosi Ahohu purusahoram sonbho colerosi Dhorinom dhorinom sohosro sirasam Dhorinom dhorinam sohosra sirasam Vonde

Om Shanti, Om Shanti

Shonti shonti

Shoutoy $\mathrm{Om}_{\mathrm{m}}$

MADONNA 

$\alpha$-Tocopherol, lycopene,

$\beta$-carotene and lutein reduce

the activities of protein

kinase $C-\alpha, \beta \|$ and $\delta$

Merel Hazewindus

Guido R.M.M. Haenen

Antje R. Weseler

Aalt Bast

Nutrim School for Nutrition, Toxicology and Metabolism, Maastricht University Medical Centre (MUMC+),

PO box 616,6200 MD Maastricht, The Netherlands, m.hazewindus@maastrichtuniversity.nl 


\section{Abstract}

Tomatoes have been associated to reduce chronic inflammation. Important constituents in tomatoes that display an anti-inflammatory potential are $\alpha$-tocopherol, lycopene, $\beta$-carotene and lutein. The enzyme protein kinase $C$ (PKC) is involved in the downstream activation of the inflammatory process. In this study the capability of $\alpha$-tocopherol to in-activate the PKC isoforms $\alpha, \beta I$ and $\delta$, was investigated. $\alpha$-Tocopherol effectively inhibited PKC- $\alpha, \beta I$ and $\delta$. Furthermore, the mode of action of the carotenoids lycopene, $\beta$-carotene and lutein on activation of these PKC-isoforms was studied. These carotenoids inhibited PKC- $\alpha$, PKC- $\beta I I$ and PKC- $\delta$ activity in the same order of magnitude as $\alpha$-tocopherol. This anti-inflammatory potency was corroborated by the reduction of PKC activity by $\alpha$-tocopherol, lycopene, $\beta$ carotene and lutein in cultured endothelial cells.

The inhibitory effect on several PKC-isoforms demonstrates the multi-faceted role of $\alpha$-tocopherol, lycopene, $\beta$-carotene and lutein in the inflammatory response and highlights the potential health benefits of these phytochemicals.

\section{Keywords}

Inflammation, lycopene, $\alpha$-tocopherol, tomatoes, protein kinase C-isoforms

\section{Abbreviations}

Protein kinase C (PKC); nuclear transcription factor kappa B (NF-кB) 


\subsection{Introduction}

Conditions such as type II diabetes, hypertension and atherosclerosis are characterized by a low-grade systemic inflammation $(1,2)$. It is generally accepted that consumption of fruits and vegetables has the potency to mitigate chronic inflammation (3-5). Tomatoes have been found to mitigate the inflammatory process (6). The carotenoid lycopene, abundantly found in tomato products, appears to provide a major contribution to this anti-inflammatory effect (6-8).

The inflammatory process is initiated by several inflammatory mediators, of which the tran-

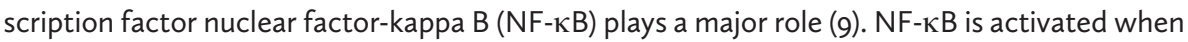
its inhibitor protein $1 \kappa B$, is phosphorylated by kinases $(10,11)$. It is known that the enzyme protein kinase $C$ (PKC) regulates the downstream pathway of NF- $\kappa B$ activation (10, 12). There is evidence that $\alpha$-tocopherol as well as carotenoids inhibit NF-KB activation $(8,13)$. For $\alpha$ tocopherol it has been demonstrated that inactivation of PKC- $\alpha$ by modulating its phosphorylation state prevents NF-KB activation, which results in an anti-inflammatory effect (14). Beside PKC- $\alpha$ also other isoforms of PKC, i.e. $\beta I I$ and $\delta$, are active in controlling the NF- $K B$ pathway $(15,16)$. This prompted us to examine the potency of $\alpha$-tocopherol to inhibit PKC$\beta I I$ and $-\delta$. Moreover, the carotenoids lycopene, $\beta$-carotene and lutein were studied, to reveal the potential role of inactivation of these PKC-isoenzymes in their anti-inflammatory mode of action. 


\subsection{Materials and methods}

\subsubsection{Materials}

$\beta$-carotene and $\alpha$-tocopherol were purchased from Sigma Chemical Co. (Germany). Lycopene and lutein were supplied by Extrasynthese (France). A selective PKC inhibitor (S)-2,6-diamino$\mathrm{N}$-\{[1'-(1"-oxotridecyl)-2'-piperidinyl]methyl\}hexanamide $2 \mathrm{HCl}, \mathrm{PKC}$ kinase activity kit, recombinant (GST-tag) active human PKC- $\alpha$, PKC- $\beta$ II and PKC- $\delta$ were purchased from ENZO life sciences (USA). All other chemicals were of analytical grade.

\subsubsection{Measurement PKC isoforms}

PKC activity of different PKC isoforms were analysed with a PKC activity kit (ENZO life sciences, USA). The inhibitors, lycopene, $\beta$-carotene, lutein and $\alpha$-tocopherol were dissolved in chloroform, evaporated under a nitrogen stream and dissolved to a final concentration of 5 $\mu M$. The synthetic PKC inhibitor (S)-2,6-diamino-N-\{[1'-(1"-oxotridecyl)-2'-piperidinyl]methyl\} hexanamide $2 \mathrm{HCl}(\mathrm{NCP})(50 \mu \mathrm{M})$ was used as a control. Human active PKC isoforms were diluted to a final concentration of $150 \mathrm{ng} / \mathrm{ml}$. The assay was performed as described in the manufacturer's instructions.

\subsubsection{Cell culture}

Immortalized human umbilical vein cells (CRL 1730; American Type Cell Culture, USA) were cultured in F12K medium (Gibco, UK) containing $10 \%$ heat activated fetal calf serum FCS (Gibco, UK), 100 units/ml penicillin (Gibco, UK), 100 \%g/ml streptomycine (Gibco, UK), 20 mg endothelial cell growth supplement (BD Biosciences,UK) and $5 \mathrm{ml}$ heparin (Leo pharma, Belgium). Lycopene, $\beta$-carotene, lutein and $\alpha$-tocopherol were dissolved in chloroform, evaporated under a nitrogen stream and dissolved in $5 \mu$ l tetrahydrofuran , $5 \mu \mathrm{FCS}$ and $990 \mu \mathrm{F} \mathrm{F}_{12} \mathrm{~K}$ medium. The final concentrations of lycopene, $\beta$-carotene, lutein and $\alpha$-tocopherol was $5 \mu \mathrm{M}$. HUVEC's were grown to $90 \%$ confluence in 6-wells plates, the cells were washed with HBSS (Gibco, UK) and pre-treated for $1 \mathrm{~h}$ lycopene, $\beta$-caroten, lutein and $\alpha$-tocopherol. The cells were washed and challenged with PMA (100 $\mathrm{nM})$ and subsequently lysed and the protein content was determined with the BSA method (Biorad, Germany), the cell fractions were stored at $-80{ }^{\circ} \mathrm{C}$ until further analyses were performed. Controls were incubated with solvent only.

\subsubsection{PKC activity in cells}

PKC activity in cytosolic fractions of HUVEC was determined with a PKC kinase activity kit (ENZO life sciences, USA). The final concentrations of lycopene, $\beta$-carotene, lutein and $\alpha$ tocopherol was $5 \mu \mathrm{M}$. The PKC inhibitor (S)-2,6-diamino-N-\{[1'-(1"-oxotridecyl)-2'-piperidinyl] methyl\}hexanamide $2 \mathrm{HCl}(50 \mu \mathrm{M})$ was used as a control. The assay was performed as described in the manufacturer's instructions. 


\subsubsection{Statistics}

All experiments were performed at least in triplicate and data are presented as mean \pm SD. The statistical significance of the difference between the effect of the test-compounds were compared to the control samples (containing no inhibitors). Statistical analysis was carried out using a Student's $t$-test or for samples which were not normally distributed, the MannWhitney $\mathrm{U}$ test. P-values $\leq 0.05$ were considered statistically significant. 


\subsection{Results}

\subsubsection{Inhibition of PKC isoforms}

The inhibitory effect of $5 \mu \mathrm{M} \alpha$-tocopherol on PKC- $\alpha$ activity was $95 \pm 5 \%$. $\alpha$-Tocopherol reduced the activity of PKC- $\beta \|$ and PKC- $\delta$ by $56 \pm 2 \%$ and $72 \pm 2 \%$, respectively.

The carotenoids lycopene, $\beta$-carotene and lutein $(5 \mu \mathrm{M})$ effectively inhibited PKC- $\alpha$ activity with 83 to $87 \%$. The inhibition of PKC- $\beta \mathrm{II}$ and PKC- $\delta$ by the tested phytochemicals ranged from 57 to $78 \%$ (figure 1 ).

$\alpha$-Tocopherol reduced significantly PKC activity in HUVEC by $63 \pm 2 \%$.

The carotenoids lycopene, $\beta$-carotene and lutein also effectively reduced PKC activity in these cultured endothelial cells. The inhibition was $52 \pm 2 \%, 48 \pm 4 \%$ and $74 \pm 2 \%$, respectively (figure 2 ). 
Figure 1. Inhibition of the PKC isoforms PKC- $\alpha,-\beta I I$ and $-\delta$, by $\alpha$-tocopherol and the carotenoids lycopene, $\beta$-caroten and lutein

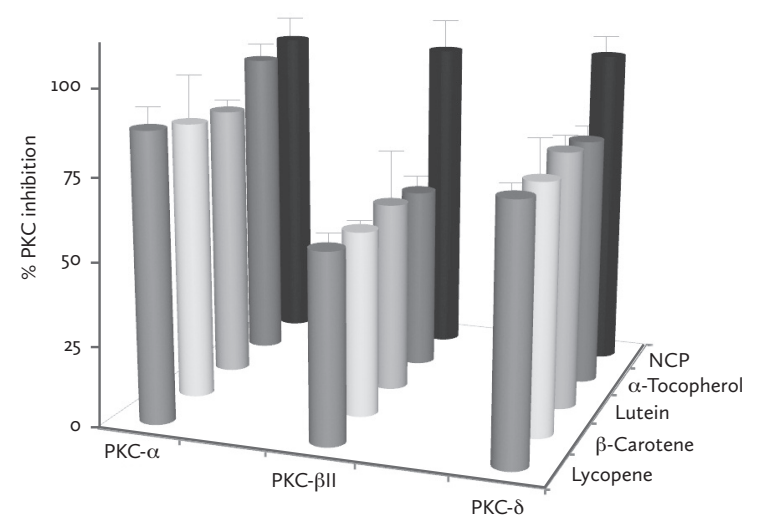

The final concentration of the phytochemicals was $5 \mu \mathrm{M}$. The synthetic inhibitor NCP was used as positive control. Data are related to the control (without inhibitor) and presented as mean \pm S.D. of 3 triplicates; all inhibitors had an effect that was significantly different $(p \leq 0.05)$ from the control (without inhibitor).

Figure 2. Inhibition of PKC activity in cultured endothelial cells by $\alpha$-tocopherol and the carotenoids lycopene, $\beta$-caroten and lutein.

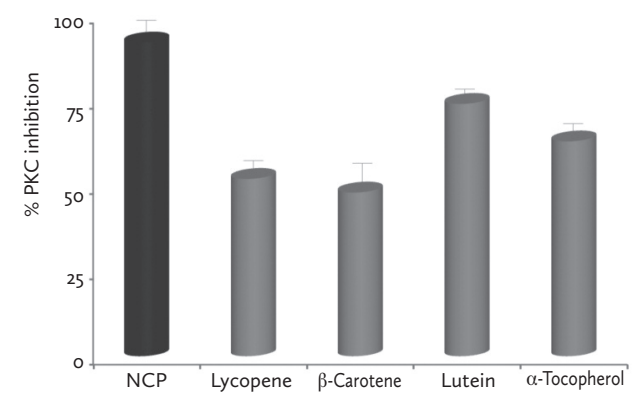

HUVEC were pre-treated with the compounds for $\mathrm{Ih}$ with a final concentration of $5 \mu \mathrm{M}$. Cell lysates were analyzed for PKC activity. The synthetic inhibitor NCP was used as positive control. Data are related to the control (without inhibitor) and presented as mean \pm S.D. of 3 triplicates; all inhibitors had an effect that was significantly different $(p \leq 0.05)$ from the control (without inhibitor). 


\subsection{Discussion}

Protein kinase $C$ plays an important role in the onset of the inflammatory process (figure 3 ) $(15,16)$. Besides PKC- $\alpha$, the $\beta I I$ and $\delta$ isoforms of PKC are upstream of the activation of NF$\kappa B$, which is a pivotal event in the inflammatory process. $(17,18)$. Both PKC- $\alpha$ and $\beta I I$ have been directly linked to the activation of NF-KB (17, 19-21). PKC- $\beta$ II can control NF- $\kappa B$ activation through selective regulation of the IKB kinase (21). Although PKC- $\delta$ is reported to delay the translocation of NF-KB to the nucleus, (17) the overall effect of this PKC isoform is pro-inflammatory (22-24). In general, inhibition of PKC activity reduces inflammation (25).

Azzi and co-workers have extensively shown that $\alpha$-tocopherol inhibits PKC- $\alpha(13,14,26)$, which is implicated in the anti-inflammatory effect of this phytochemical. The principal aim of the study was to investigate the inhibitory potential of $\alpha$-tocopherol and several carotenoids on PKC isoforms involved in inflammation.

Figure 3. The role of PKC in the process of inflammation

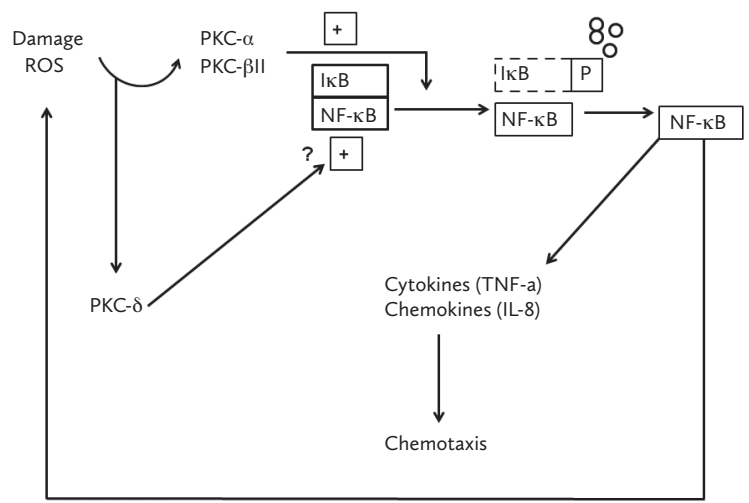

Pro-inflammatory stimuli such as reactive oxygen species (ROS), diacylglycerol (DAG) or the pro-inflammatory cytokine tumor necrosis factor-alpha (TNF- $\alpha$ ) that damage tissues and cells, trigger the activation of PKC. Subsequently, PKC- $\alpha$ and $\beta$ II initiate the phosphorylation of IKB which causes the release and activation of $\mathrm{NF}-\kappa \mathrm{B}$. Activated NF-KB translokates to the nucleus where it starts gene expression and production of inflammatory mediators such as cytokines and chemokines that results in chemotaxis and in turn activate PKC. 
In accordance with previous studies, $\alpha$-tocopherol appeared to be a potent inhibitor of PKC$\alpha(14,27,28)$. In addition, $\alpha$-tocopherol efficiently inhibited PKC- $\beta$ II and PKC- $\delta$. These results indicate that in the anti-inflammatory effect of $\alpha$-tocopherol, besides the inhibition of PKC$\alpha$, also the inhibition of PKC- $\beta$ II and PKC- $\delta$ is of relevance. The inhibitory effect on several isoforms demonstrates the versatile role of $\alpha$-tocopherol in the inflammatory response which boosts its biological importance. Although the effect on an isolated isoform might be relatively small, the combined effect of $\alpha$-tocopherol on various isoforms will add up to give a more substantial inhibition of PKC. This anti-inflammatory potency was corroborated by the reduction of PKC activity by $\alpha$-tocopherol in cultured endothelial cells.

Another principal that underlines the impact of nutrition on health is that different phytochemicals may act on the same target. The present study showed that lycopene, $\beta$-carotene as well as lutein effectively inhibited PKC- $\alpha$, PKC- $\beta$ II and PKC- $\delta$ activity in the same order of magnitude as $\alpha$-tocopherol (figure 1 ). In line with this finding, all these phytochemicals were also approximately equipotent as $\alpha$-tocopherol in reducing PKC activity in cultured endothelial cells (figure 2).

Apparently, the biological effect of the tested carotenoids and that of $\alpha$-tocopherol on PKC overlaps. This overlap in PKC inhibition indicates that a combination of these phytochemicals, that are abundantly found in fruits and vegetables, has a higher anti-inflammatory potential than one of the constituting phytochemicals in isolation. An example of such an interplay between phytochemicals was recently observed in an anti-inflammatory effect of tomato ketchup which contains relatively large quantities of lycopene and $\alpha$-tocopherol. Tomato ketchup reduced chemotaxis much more effectively than lycopene or $\alpha$-tocopherol (6). This points to a concerted action of the phytochemicals in ketchup on the same or inter-connected targets which may result in additive or synergistic anti-inflammatory effects. Moreover, this is of relevance in the health benefit of fruits and vegetables in chronic deceases characterized by a low-grade systemic inflammation.

In conclusion, the present study highlights not only the inhibition of PKC- $\alpha$, but also that of the $\beta I I$ and $\delta$ isoforms of PKC in the potential health effect of $\alpha$-tocopherol as well as that of lycopene, $\beta$-carotene and lutein. 


\section{References}

1. Prasad H, Ryan DA, Celzo MF, Stapleton D. Metabolic syndrome: definition and therapeutic implications. Postgrad Med. 2012 Jan;124:21-30.

2. Ren J, Kelley RO. Cardiac health in women with metabolic syndrome: clinical aspects and pathophysiology. Obesity (Silver Spring). 2009 Jun;17:1114-23.

3. Ren J, Zhu W, Dai H, Chen Z, Chen L, Fang L. Nutritional intervention in the metabolic syndrome. Asia Pac J Clin Nutr. 2007;16 Suppl 1:418-21.

4. Riso P, Visioli F, Grande S, Guarnieri S, Gardana C, Simonetti P, Porrini M. Effect of a tomato-based drink on markers of inflammation, immunomodulation, and oxidative stress. J Agric Food Chem. 2006 Apr 5;54:2563-6.

5. Esfahani A, Wong JM, Truan J, Villa CR, Mirrahimi A, Srichaikul K, Kendall CW. Health effects of mixed fruit and vegetable concentrates: a systematic review of the clinical interventions. J Am Coll Nutr. 2011 Oct;30:285-94.

6. Hazewindus M. Protection against chemotaxis in the anti-inflammatory effect of tomato ketchup. PLoS One. 2012.

7. Bast MHGRMMHARWA. The anti-inflammatory effect of lycopene complements the antioxidant action of ascorbic acid and $\alpha$-tocopherol. Food Chemistry. 201215 May 2012;132:954-8.

8. Palozza P, Parrone N, Catalano A, Simone R. Tomato lycopene and inflammatory cascade: basic interactions and clinical implications. Curr Med Chem. 2010;17:2547-63.

9. Baker RG, Hayden MS, Ghosh S. NF-kappaB, inflammation, and metabolic disease. Cell Metab. 2011 Jan 5;13:11-22.

10. Oeckinghaus A, Hayden MS, Ghosh S. Crosstalk in NF-kappaB signaling pathways. Nat Immunol. 2011 Aug;12:695-708.

11. Ghosh S, Hayden MS. New regulators of NF-kappaB in inflammation. Nat Rev Immunol. 2008 Nov;8:837-48.

12. Hayden MS, Ghosh S. NF-kappaB, the first quarter-century: remarkable progress and outstanding questions. Genes Dev. 2012 Feb 1;26:203-34.

13. Azzi A, Ricciarelli R, Zingg JM. Non-antioxidant molecular functions of alpha-tocopherol (vitamin E). FEBS Lett. 2002 May 22;519:8-10.

14. Ricciarelli R, Tasinato A, Clement S, Ozer NK, Boscoboinik D, Azzi A. alpha-Tocopherol specifically inactivates cellular protein kinase C alpha by changing its phosphorylation state. Biochem J. 1998 Aug 15;334 ( Pt 1):243-9.

15. Breitkreutz D, Braiman-Wiksman L, Daum N, Denning MF, Tennenbaum T. Protein kinase C family: on the crossroads of cell signaling in skin and tumor epithelium. J Cancer Res Clin Oncol. 2007 Nov;133:793-808.

16. Barnett ME, Madgwick DK, Takemoto DJ. Protein kinase C as a stress sensor. Cell Signal. 2007 Sep;19:1820-9.

17. Mut M, Amos S, Hussaini IM. PKC alpha phosphorylates cytosolic NF-kappaB/p65 and PKC delta delays nuclear translocation of NF-kappaB/p65 in U1242 glioblastoma cells. Turk Neurosurg. 2010 Jul;20:277-85.

18. Min W BZ, Quan ZB, Hui ZJ, Sheng FG. The signal transduction pathway of PKC/NF-kappa B/c-fos may be involved in the influence of high glucose on the cardiomyocytes of neonatal rats. Cardiovasc Diabetol. 2009;2009 Feb 11.

19. Trushin SA, Pennington KN, Carmona EM, Asin S, Savoy DN, Billadeau DD, Paya CV. Protein kinase Calpha (PKCalpha) acts upstream of PKCtheta to activate IkappaB kinase and NF-kappaB in T lymphocytes. Mol Cell Biol. 2003 Oct;23:7068-81. 
20. Kawakami Y, Nishimoto H, Kitaura J, Maeda-Yamamoto M, Kato RM, Littman DR, Leitges M, Rawlings DJ, Kawakami T. Protein kinase C betall regulates Akt phosphorylation on Ser- 473 in a cell type- and stimulusspecific fashion. J Biol Chem. 2004 Nov 12;279:47720-5.

21. Saijo K, Mecklenbrauker I, Schmedt C, Tarakhovsky A. B cell immunity regulated by the protein kinase C family. Ann N Y Acad Sci. 2003 Apr;987:125-34.

22. Mecklenbrauker I, Saijo K, Zheng NY, Leitges M, Tarakhovsky A. Protein kinase Cdelta controls self-antigeninduced B-cell tolerance. Nature. 2002 Apr 25;416:860-5.

23. Muthusamy S, Shukla S, Amin MR, Cheng M, Orenuga T, Dudeja PK, Malakooti J. PKCdelta-dependent activation of $\mathrm{ERK}_{1} / 2$ leads to upregulation of the human $\mathrm{NHE}_{2}$ transcriptional activity in intestinal epithelial cell line C2BBe1. Am J Physiol Gastrointest Liver Physiol. 2012 Feb;302:G317-25.

24. Yamaguchi K, Ogita K, Nakamura S, Nishizuka Y. The protein kinase C isoforms leading to MAP-kinase activation in CHO cells. Biochem Biophys Res Commun. 1995 May 25;210:639-47.

25. Lu X, Bean JS, Kassab GS, Rekhter MD. Protein kinase C inhibition ameliorates functional endothelial insulin resistance and vascular smooth muscle cell hypersensitivity to insulin in diabetic hypertensive rats. Cardiovasc Diabetol. 2011;10:48.

26. Azzi A. The role of alpha-tocopherol in preventing disease. Eur J Nutr. 2004 Mar;43 Suppl 1:I/18-25.

27. Boscoboinik D, Szewczyk A, Azzi A. Alpha-tocopherol (vitamin E) regulates vascular smooth muscle cell proliferation and protein kinase C activity. Arch Biochem Biophys. 1991 Apr;286:264-9.

28. Kempna P, Reiter E, Arock M, Azzi A, Zingg JM. Inhibition of HMC-1 mast cell proliferation by vitamin E: involvement of the protein kinase B pathway. J Biol Chem. 2004 Dec 3;279:50700-9. 
0
$I$
$D$
0
-1
$m$
0
0
$D$ 
Insonity: doing the some thing over and over agoin and expecting different results.

EINSTEIN 

Protection against chemotaxis in the anti-inflammatory effect of tomato ketchup

Merel Hazewindus

Guido R.M.M. Haenen

Antje R. Weseler

Aalt Bast

Nutrim School for Nutrition, Toxicology and Metabolism, Maastricht University Medical Centre (MUMC+), 


\section{Abstract}

The consumption of tomato products has been associated with a decreased risk for chronic inflammatory diseases. In this study, the anti-inflammatory potential of tomato ketchup was investigated by studying its effect on the human monocyte-vascular endothelial cell interaction. The quantification of gene expression inflammatory mediators were assayed with RTPCR and ELISA. Chemotaxis was investigated in a monocyte migration assay.

Our experiments showed that tomato ketchup extracts significantly reduced gene expression and release of the pro-inflammatory cytokines TNF- $\alpha$ and IL-8 in lipopolysaccharide-stimulated HUVECs, whereas the release of the anti-inflammatory cytokine IL-10 was increased. Chemotaxis was effectively impeded via inhibition of gene expression of the adhesion molecules E-selectin and ICAM-1 and monocyte migration. The results consistently emphasize the contribution of lycopene to the anti-inflammatory effect of tomato ketchup. Other compounds in tomato ketchup such as $\alpha$-tocopherol and ascorbic acid appeared to strengthen the anti-inflammatory effect of lycopene.

Tomato ketchup subtly interfered with several inflammatory phases that become integrated in a clear inhibitory effect on chemotaxis. Such a pleotropic mode of action can especially be effective in mitigation of diseases characterized with prolonged by low grade inflammation.

\section{Abbreviations}

ICAM-1: intercellular adhesion molecule-1; IKB: inhibitor protein kappa B; IL: interleukin; IFN: interferon; MCP-1: monocyte chemotactic protein-1; NFKB: nuclear factor kappa B; TNF- $\alpha$ : tumor necrosis factor alpha 


\subsection{Introduction}

The consumption of tomatoes and tomato products is inversely associated with the risk for the development of inflammatory related diseases, such as atherosclerosis $(1,2)$. The underlying pathology of these diseases is characterized by prolonged and low grade inflammation that ultimately leads to tissue damage and dysfunction (3).

Inflammation is a complex biological process that consists of a cascade of sequential reactions in which the inflammatory signal is amplified. The process is initiated by the activation of nuclear transcription factors such as nuclear factor kappa B (NFkB), triggered by e.g. intrusion of bacteria or tissue damage. NFKB activation promotes the expression of several pro-inflammatory genes and the subsequent production and release of cytokines (4).

Cytokines are signaling molecules that mostly have a pro-inflammatory action (e.g. TNF- $\alpha$, IL-6, IFN- $\gamma$ ) or act as chemokines (e.g. monocyte chemotactic protein-1 (MCP-1), IL-8). An important pro-inflammatory cytokine is TNF- $\alpha$, which triggers a positive feedback loop during inflammation by activating NFKB. Some cytokines display anti-inflammatory activity (e.g. IL4 , IL-10, IL-13) (5, 6). Anti-inflammatory cytokines restrain excessive amplification of the inflammatory process via a negative control. Chemokines, which are important for the recruitment of monocytes from the circulation to the site of inflammation. In this process, referred to as chemotaxis, the concentration gradient of the chemokine IL-8 is known to be of importance $(7,8)$.

An essential feature of chemotaxis is the up-regulation of adhesion molecules such as E-selectin and intercellular adhesion molecule-1 (ICAM-1) that are expressed on endothelial cells (9). Receptors on the monocytes firmly adhere to these adhesion molecules, causing the monocytes to transmigrate through the endothelium. This migration is accompanied by differentiation of the monocytes into macrophages that phagocytose cell debris and bacteria. Chemotaxis leads to the accumulation of monocytes and macrophages in the vascular endothelium, which is the first hallmark of atherosclerotic plaque formation (8, 9). Atherosclerosis contributes to life-threatening complications such as acute coronary disorders and myocardial infarction.

It has been reported that the consumption of tomatoes and tomato products like, tomato juice, soup and paste, attenuate the inflammatory process and might protect against coronary diseases $(10,11,12,13)$. Tomatoes and tomato products contain various bio-active compounds such as carotenoids, flavonoids and vitamins. The carotenoid lycopene is the main constituent of tomatoes, followed by the vitamins $\alpha$-tocopherol and ascorbic acid (14). In-vitro, $\alpha$-toco- 
pherol and ascorbic acid reduce oxidative stress $(15,16,17)$. In-vivo, the antioxidant activity of $\alpha$-tocopherol is more subtle (18). Oxidative stress itself can initiate the inflammatory process by activating NFKB and pro-inflammatory cytokines (19).

It has been observed that lycopene inhibits the activation of $\mathrm{NFKB}(20,21)$, the release of proinflammatory cytokines $(21,22)$ and prevents the expression of adhesion molecules in vitro (23). Clinical studies support the anti-inflammatory potential of lycopene supplementation $(10,13,24)$. Furthermore, it was observed that the consumption of tomatoes and tomato products seemed to be more efficient against inflammation than lycopene supplementation. It was speculated that the presence of other bio-active compounds in tomato products contributed to this anti-inflammatory potential $(11,25)$.

Tomato products are frequently consumed in the Western World and a popular tomato product is tomato ketchup $(26,27)$. There are no reports on the effect of tomato ketchup on inflammation. In the present study we examined the effect of tomato ketchup in cultured endothelial cells on sequential phases of the inflammatory process by means of gene expression analyses, quantification of cytokine production and a bio-assay for chemotaxis involving transmigration of monocytes. The potency of tomato ketchup was estimated by assessing the anti-inflammatory effects of the hydrophilic and lipophilic extracts of tomato ketchup, and lycopene, $\alpha$-tocopherol and ascorbic acid as individual compounds. 


\subsection{Materials and methods}

\subsubsection{Materials}

Tomato ketchup was a gift from H.J. Heinz Company. Ascorbic acid, $\alpha$-tocopherol and bovine serum albumin (BSA) were purchased from Sigma Chemical Co. (St. Gallen, Germany). Lycopene was supplied by Extrasynthese (Lyon, France). Human TNF- $\alpha$ (7300 pg/mL), and IL-8 $(10 \mathrm{ng} / \mathrm{ml})$ and IL-10 $(4000 \mathrm{pg} / \mathrm{mL})$ were acquired from CLB/Sanquin (Amsterdam, The Netherlands). Human TNF- $\alpha$ were bought from R\&D Systems (Wiesbaden, Germany). All other chemicals were of analytical grade.

\subsubsection{Preparation of the tomato ketchup extracts and compounds}

Lipophilic extracts of tomato ketchup were obtained by mixing $25 \mathrm{ml}$ of chloroform to $10 \mathrm{~g}$ tomato ketchup and subsequent centrifugation for $15 \mathrm{~min}$. The lipophilic extract was then transferred to a glass test tube. With a steam of nitrogen gas at room temperature the chloroform was evaporated to isolate the lipophilic compounds and thereafter, dissolved in $25 \mu \mathrm{l}$ tetrahydrofuran, $25 \mu \mathrm{FCS}$ and $950 \mu \mathrm{F} 12 \mathrm{~K}$ culture medium. The hydrophilic extract of tomato ketchup was obtained by adding $25 \mathrm{ml}$ of $\mathrm{F}_{12} \mathrm{~K}$ culture medium to $10 \mathrm{~g}$ tomato ketchup and subsequent centrifugation for $15 \mathrm{~min}$. The hydrophilic extract was then transferred to a $15 \mathrm{ml}$ tube and stored on ice until further use. Lycopene and $\alpha$-tocopherol were dissolved in chloroform, evaporated under a nitrogen stream and dissolved in $25 \mu$ tetrahydrofuran, $25 \mu \mathrm{l}$ FCS and $950 \mu \mathrm{l} \mathrm{F12K} \mathrm{culture} \mathrm{medium.} \mathrm{Ascorbic} \mathrm{acid} \mathrm{was} \mathrm{dissolved} \mathrm{in} 10 \mathrm{ml} \mathrm{F12K}$ culture medium and stored on ice. The final concentrations of lycopene, $\alpha$-tocopherol and ascorbic acid as single compounds and in the tomato ketchup extracts was $7.5 \mu \mathrm{M}, 1.4 \mu \mathrm{M}$ and $55 \mu \mathrm{M}$, respectively.

\subsubsection{Cell culture}

Immortalized human umbilical vein cells (HUVEC) (CRL 1730; American Type Cell Culture, USA) were cultured in $\mathrm{F}_{12} \mathrm{~K}$ medium (Gibco, UK) containing $10 \%$ heat activated fetal calf serum (FCS) (Gibco, UK), 100 units/ml penicillin (Gibco, UK), $100 \mu \mathrm{g} / \mathrm{ml}$ streptomycine (Gibco, UK), $20 \mathrm{mg}$ endothelial cell growth supplement (BD Biosciences,UK) and $5 \mathrm{ml}$ heparin (Leo pharma, Belgium). Human monocytes U937 (CRL-1593.2; American Type Cell Culture, USA) were cultured in RPMI-1640 medium containing $200 \mathrm{mg} / \mathrm{L} \mathrm{I}$-glutamine and $25 \mathrm{mM}$ HEPES (Gibco, UK), supplemented with 100 units/ml penicillin (Gibco, UK), $100 \mu \mathrm{g} / \mathrm{ml}$ streptomycin (Gibco, UK), $10 \%$ heat inactivated fetal calf serum (Gibco, UK) in a $5 \% \mathrm{CO}_{2}$ incubator at $37^{\circ} \mathrm{C}$. Cells were detached from their substratum by trypsin/EDTA (Gibco, UK). HUVEC's were grown to $90 \%$ confluence in 6-wells plates, the cells were washed with HBSS (Gibco, UK) and pre-treated for $\mathrm{I} \mathrm{h}$ with single antioxidants (lycopene $7.5 \mu \mathrm{M}, \alpha$-tocopherol $1.4 \mu \mathrm{M}$ and ascorbic 
acid $55 \mu \mathrm{M}$ ) or a combination of these three antioxidants and with separate or combined tomato ketchup extracts (hydrophilic and lipophilic). The cells were washed and challenged with TNF- $\alpha$ (1ong/ml) for 6 and $24 \mathrm{~h}$. The medium was used to perform an enzyme-linked immunosorbent assay (ELISA) and the chemotaxis assay. The control samples were incubated with solvent only.

\subsubsection{Cytokine quantification}

Tumor necrosis factor- $\alpha$, IL- 8 and IL-10 were quantified using PeliKine Compact human ELISA kits (CLB/Sanquin, The Netherlands) based on appropriate and validated sets of monoclonal antibodies. Assays were performed as described in the manufacturer's instructions. Cytokine levels were related to that of the control incubation without tomato ketchup extracts or bioactive compounds. The tetrahydrofuran and FCS (both 0.05\%) did not show any influence on the TNF- $\alpha$ induced cytokine release (data not shown).

\subsubsection{RNA isolation, reverse transcription-polymerase chain reaction (RT-PCR) and data analysis}

Total RNA was isolated using Qiazol lysis reagent (Qiagen, The Netherlands) followed by purification using miRNeasy-kit (Qiagen, The Netherlands) according to the instructions of the manufacturer. RNA concentration and purity were measured using the Nanodrop system (IsoGen Life Science, The Netherlands). RNA purity was assumed when $A_{260} / A_{280}$ ratios above 2 and $A_{260} / A_{230}$ proportion above 1.9 for all samples.

RNA isolation was performed on individual samples, using the iScript cDNA synthesis kit (BioRad, The Netherlands). cDNA was synthesized from 0.5 $\mu$ g RNA per sample and diluted 15× in RNase-free water. RT-PCR reactions were performed with iQ SYBR Green Supermix (BioRad, The Netherlands) using the MylQ single-color real-time PCR detection system (Bio-Rad, The Netherlands). Primers for the inflammatory markers TNF- $\alpha$, IL-8, IL-10, E-selectin, ICAM-1, and IKb; and the housekeeping gene $\beta$-actin were designed using Primer Express software (Applied Biosystems). Sequences of the primer pairs used were the following: for TNF- $\alpha$ 5'TCAATCGGCCCGACTATCTC- 3'(forward), 5'- CAGGGCAATGATCCCAAAGT-3'(reverse), for IL-8 5'- GGACAAGAGCCAGGAAGAAA- 3' (forward), 5'- AAATTTGGGGTGGAAAGGTT- 3' (reverse), for IL-10 5'- GCTGTCATCGATTTCTTCCC- 3' (forward), 5'- CTCATGGCTTTGTAGATGCCT- 3' (reverse), for e-selectin 5'- CCCTAGCAAGGCATGATGTT- 3' ( forward), 5'- GGCCTCATGGAAGTTTTTCA-3' (reverse), for ICAM-1 5'- CTGAGCAATGTGCAAGAAGATAGC-3' (forward), 5'- CCCGTTCTGGAGTCCAGTACA-3' (reverse), for IKb 5'- CTACACCTTGCCTGTGAGCA-3' (forward), 5'- TCCTGAGCATTGACATCAGC-3' (reverse) and for $\beta$-actin 5'- $\beta$-actin-3' 
(forward), 5'- CCTGGCACCCAGCACAAT-3' (reverse). Then, $2.5 \mu \mathrm{l}$ of $0.3 \mu \mathrm{M}$ forward and reverse primer was mixed with $2.5 \mu \mathrm{l}$ water and $12.5 \mu \mathrm{l}$ SYBR Green Supermix (Bio-Rad) and added to $5 \mu \mathrm{l}$ sample, yielding a final volume of $25 \mu \mathrm{l}$ per well of a 96-well PCR plate. qRTPCR was performed using a MyiQ Single Color real-time PCR detection system (Bio-Rad), according to the following protocol: denaturation at $95^{\circ} \mathrm{C}$ for $3 \mathrm{~min}$ was followed by 40 cycles at $95^{\circ} \mathrm{C}(15 \mathrm{~s})$ and $60{ }^{\circ} \mathrm{C}(45 \mathrm{~s})$. After PCR, a melt curve $\left(60-95^{\circ} \mathrm{C}\right)$ was produced for product identification and purity. The PCR efficiency of all seven primer sets, assessed by measuring cDNA dilution curves, was at least 90\%. Data were analyzed using the MyiQ software system (Bio-Rad) and were finally expressed as relative gene expression (fold increase compared to control samples) according to the $2^{-\Delta \Delta \mathrm{X} \tau}$ method (28) .

\subsubsection{Chemotaxis assay}

The chemotaxis assay was adapted from Denton et al. and Yang et al. $(29,30)$ with minor modifications. Briefly, after treatment with lycopene, $\alpha$-tocopherol, ascorbic acid or tomato ketchup extracts and $24 \mathrm{~h}$ exposure with TNF- $\alpha$ as described in 2.3 , the medium of the HUVEC's was collected and transferred $(800 \mu \mathrm{l})$ into the lower chamber of a transwell insert $\left(5 \mu \mathrm{M}\right.$ pore size, Costar, USA). U937 cells were added to the upper chamber ( $\left.10^{6} \mathrm{cells} / \mathrm{ml}\right)$ and allowed to migrate through the polycarbonate membrane at $37 \mathrm{C}^{\circ}, 5 \% \mathrm{CO}_{2}$. After 90 min the cells in the lower wells were collected by centrifugation at $3000 \times \mathrm{g}$ for $5 \mathrm{~min}$ and directly counted under a microscope.

\subsubsection{Statistics}

All experiments were performed, at least, in triplicate. Results are given as mean SD. All data were checked for normal distribution. Statistically significant differences between the effects of the experimental conditions and the controls (containing neither tomato ketchup extracts nor lycopene, ascorbic acid or $\alpha$-tocopherol), were assessed by a Mann-Whitney $U$ test corrected with a Bonferroni test, using SPSS.15. P-values $\leq 0.05$ were considered statistically significant. 


\subsection{Results}

\subsubsection{Gene expression of inflammatory mediators in HUVEC}

The gene expression of the pro-inflammatory cytokines TNF- $\alpha$ and IL- 8 was reduced by the hydrophilic, lipophilic as well as the mixture of both tomato ketchup extracts $(P \leq 0.05)$ (figure $1 \mathrm{~A}-\mathrm{B})$. The gene expression of the anti-inflammatory cytokine IL-10 was stimulated neither by both individual tomato ketchup extracts, nor by the combination of these extracts.

The gene expression of the inhibitor protein $1 \kappa B$ was reduced by the lipophilic ketchup extract (figure 2). The gene expression of the adhesion molecule E-selectin was reduced by the hydrophilic, lipophilic ketchup extracts and the mixture of both ketchup extracts (figure 3). The lipophilic ketchup extract and the mixture of both extracts effectively decreased ICAM-1 gene expression (figure 3), while the hydrophilic extract exerted a slight stimulatory effect.

Lycopene, $\alpha$-tocopherol, ascorbic acid and the mixture of these three antioxidants reduced TNF- $\alpha$ and IL-8 gene expression ( $P \leq 0.05)$. The gene expression of the anti-inflammatory cytokine IL-10 was significantly stimulated by lycopene, $\alpha$-tocopherol and the mixture of all three antioxidants $(P \leq 0.05$ ) (figure 1 C). Lycopene, $\alpha$-tocopherol, ascorbic acid and the mixture of all three antioxidants effectively inhibited $1 \kappa B$ gene expression (figure 2 ). Lycopene, $\alpha$-tocopherol and ascorbic acid, as well as the mixture of all three antioxidants efficiently reduced

Figure $1^{A-C}$. The effect of tomato ketchup extracts and lycopene, $\alpha$-tocopherol and ascorbic acid on gene expression of TNF- $\alpha$ (panel A) IL- 8 (panel B) and IL-10 (panel C) and the release of these cytokines in the culture medium by HUVEC.

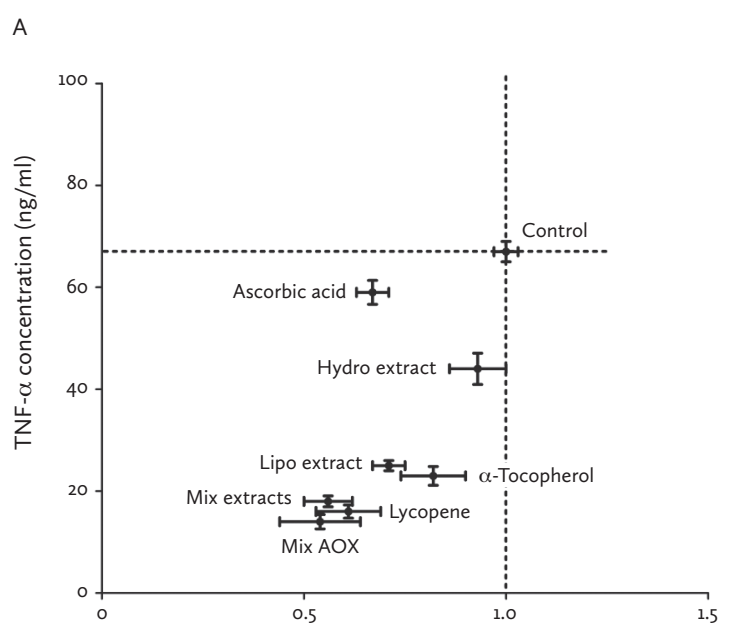




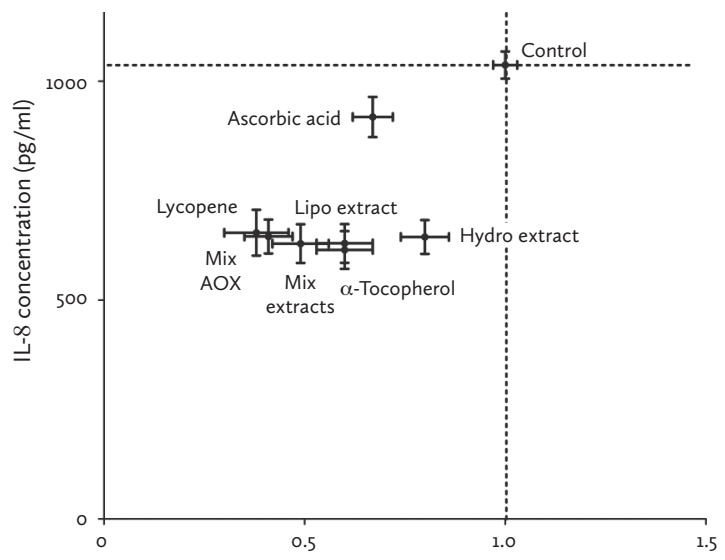

C

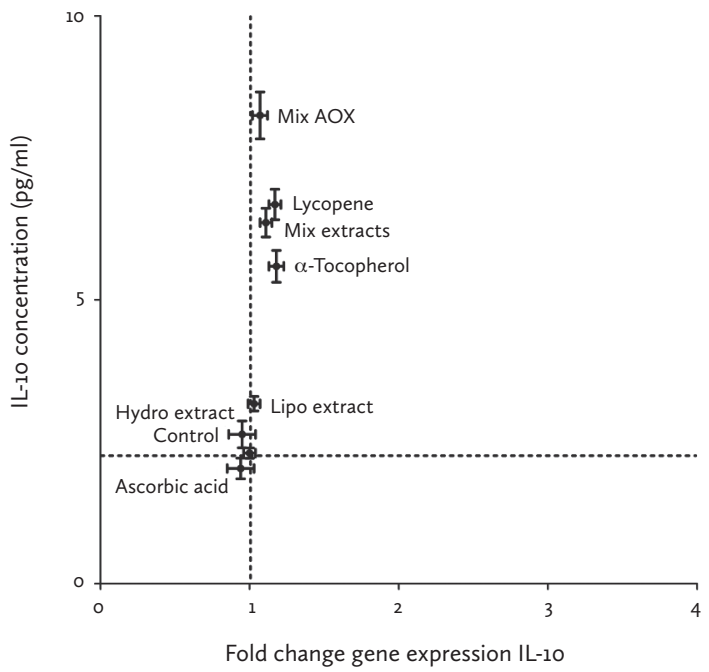

HUVEC were pre-incubated for $\mathrm{I} h$ with tomato ketchup extracts, lycopene $(7.5 \mu \mathrm{M}), \alpha$-tocopherol $(1.4 \mu \mathrm{M})$ and ascorbic acid $(55 \mu \mathrm{M})$ and stimulated with TNF- $\alpha$ (10ng/ml) for 6 or $24 \mathrm{~h}$. The inhibitory effect on gene expression and protein production of TNF- $\alpha$ (panel A), IL-8 (panel B) on gene expression and protein production, were in the same order of magnitude and showed a significant correlation.

Mix AOX: the combination of the antioxidants lycopene $(7.5 \mu \mathrm{M}), \alpha$-tocopherol $(1.4 \mu \mathrm{M})$ and ascorbic acid $(55 \mu \mathrm{M})$; Hydro: hydrophilic tomato ketchup extract; Lipo: lipophilic tomato ketchup extract. 
Figure 2. The effect of tomato ketchup extracts, lycopene, $\alpha$-tocopherol and ascorbic acid on gene expression of IKB in HUVEC

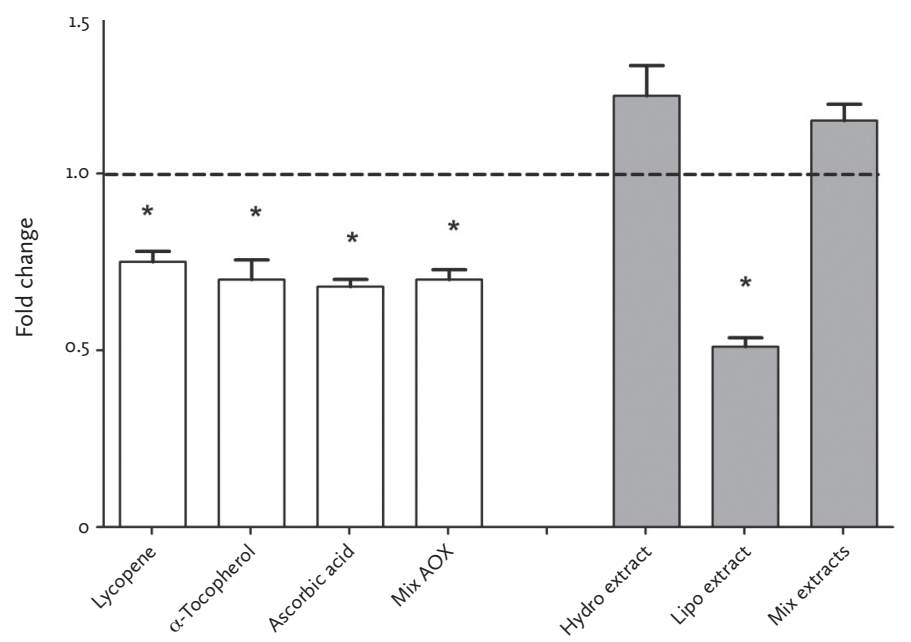

HUVEC were pre-incubated for $\mathrm{l} h$ with tomato ketchup extracts, lycopene (7.5 $\mu \mathrm{M}), \alpha$-tocopherol $(1.4 \mu \mathrm{M})$ and ascorbic acid $(55 \mu \mathrm{M})$ and stimulated with TNF- $\alpha$ (1ong/ml) for $6 \mathrm{~h}$. Data are presented as mean \pm S.E.M. of 3 triplicates, $*(p \leq 0.05)$ significantly lower than the control (TNF- $\alpha$ only).

Mix AOX: the combination of the antioxidants lycopene $(7.5 \mu \mathrm{M}), \alpha$-tocopherol $(1.4 \mu \mathrm{M})$ and ascorbic acid $(55 \mu \mathrm{M})$; Hydro: hydrophilic tomato ketchup extract; Lipo: lipophilic tomato ketchup extract.

Figure 3. The effect of tomato ketchup extracts, lycopene, $\alpha$-tocopherol and ascorbic acid on gene expression of E-selectin and ICAM-1 in HUVEC

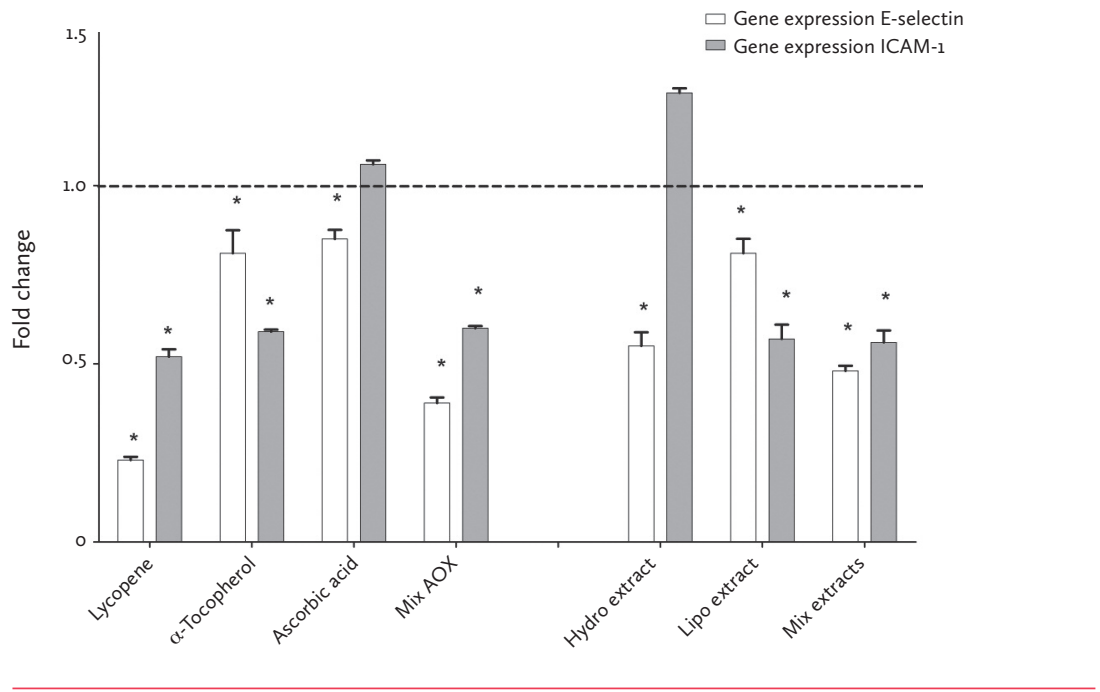

HUVEC were pre-incubated for $\mathrm{I} h$ with tomato ketchup extracts, lycopene $(7.5 \mu \mathrm{M}), \alpha$-tocopherol $(1.4 \mu \mathrm{M}$ and ascorbic acid $(55 \mu \mathrm{M})$ and stimulated with TNF- $\alpha$ (1ong/ml) for $6 \mathrm{~h}$. Data are presented as mean \pm S.E.M. of 3 triplicates, $*(p \leq 0.05)$ significantly lower than the control (TNF- $\alpha$ only).

Mix AOX: the combination of the antioxidants lycopene (7.5 $\mu \mathrm{M}), \alpha$-tocopherol (1.4 $\mu \mathrm{M})$ and ascorbic acid $(55 \mu \mathrm{M})$; Hydro: hydrophilic tomato ketchup extract; Lipo: lipophilic tomato ketchup extract. 
E-selectin gene expression (figure 3). Lycopene and $\alpha$-tocopherol and the mixture of all three antioxidants significantly reduced the expression of ICAM-1, while ascorbic acid showed a slight increase/did not affect ICAM-1 gene epxression (figure 3).

\subsubsection{Cytokine quantification in HUVEC}

Both tomato ketchup extracts inhibited the release of TNF- $\alpha$ and IL- 8 in the culture medium (figure 1). The lipophilic tomato ketchup extract and the mixture of both extracts stimulated the release of the anti-inflammatory cytokine IL-10 in the culture medium (figure 1). For both TNF-a and IL-8, the ketchup extract induced inhibition of gene expression correlated with the attenuated secretion of the cytokines on protein level (figure $1 \mathrm{~A}-\mathrm{B}$ ).

Lycopene, $\alpha$-tocopherol, ascorbic acid and the mixture of these three antioxidants reduced the release of TNF- $\alpha$ and IL-8, and stimulated the release of IL-10 $(P \leq 0.05)$. The release of TNF- $\alpha$ and IL- 8 correlated with the decrease in gene expression, while the increased IL-10 secretion was not accompanied by a significant change in its gene expression (figure 1 ).

\subsubsection{Chemotaxis}

HUVEC were pre-treated with lycopene, $\alpha$-tocopherol, ascorbic acid and extracts of tomato ketchupas described in section 2.5. The culture medium was tested for the concentration of IL-8 and used to attract monocytes to the lower compartment of the transwell system in a chemotaxis bio-assay.

The migration of monocytes was significantly reduced by the hydrophilic and particularly the lipophilic tomato extract. The combination of both extracts reduced migration by the same extent as the lipophilic extract (figure $4 \mathrm{~A}$ ). $\alpha$-Tocopherol, ascorbic acid and mainly lycopene inhibited monocyte migration significantly (figure $4 \mathrm{~A}$ ). The combination of lycopene, $\alpha$-tocopherol and ascorbic acid inhibited chemotaxis even more extensively than the individual antioxidants.

A positive correlation $(r=0.7316, P \leq 0.05)$ between the migration of monocytes and the concentration of IL-8 in the culture medium was found (figure $4 \mathrm{~B}$ ). 
Figure $4^{A, B}$. The effect of tomato ketchup extracts, lycopene, $\alpha$-tocopherol and ascorbic acid on chemotaxis and the relation between cell migration and IL- 8 concentrations

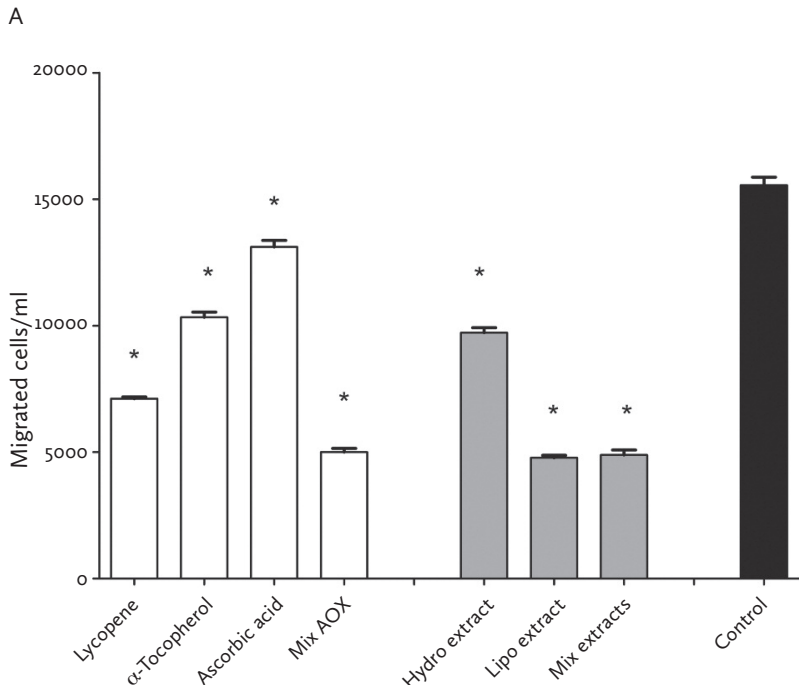

B

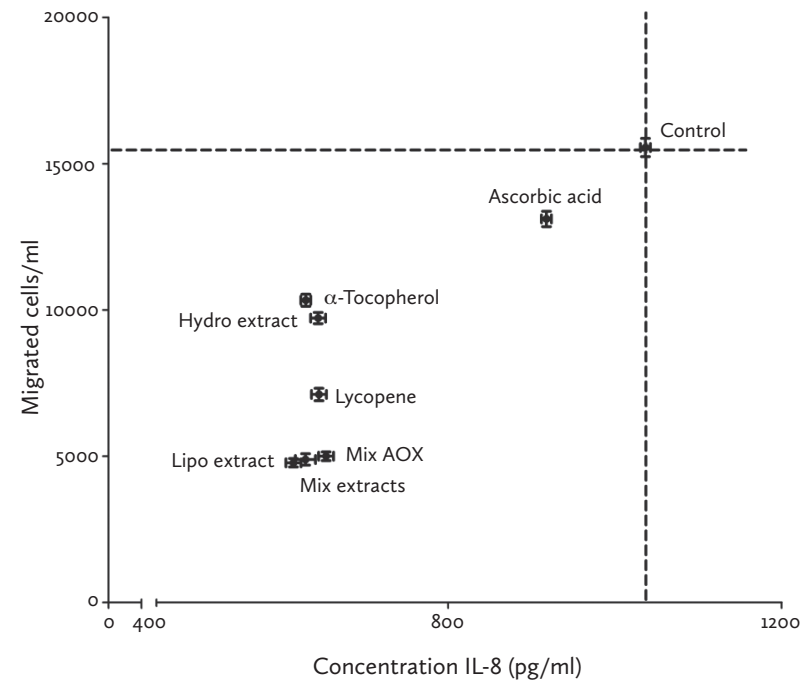

Panel A: HUVEC were pre-incubated for $\mathrm{I} h$ with tomato ketchup extracts, lycopene $(7.5 \mu \mathrm{M}), \alpha$-tocopherol (1.4 $\mu \mathrm{M}$ and ascorbic acid $(55 \mu \mathrm{M})$ and stimulated with TNF- $\alpha$ (1ong/ml) for $24 \mathrm{~h}$. The medium of HUVEC was used for the migration ( $90 \mathrm{~min}$ ) of monocytes (cells $/ \mathrm{ml}$ ).

Panel B: correlation between the concentration IL- $8(\mathrm{pg} / \mathrm{ml})$ and migrated monocytes $/ \mathrm{ml}(r=0.7316 ; \mathrm{p} \leq$ $0.05)$. Data are presented as mean \pm S.E.M. of 3 triplicates, $*(p \leq 0.05)$ significantly lower than the control (TNF- $\alpha$ only).

Mix AOX: the combination of the antioxidants lycopene (7.5 $\mu \mathrm{M}), \alpha$-tocopherol $(1.4 \mu \mathrm{M})$ and ascorbic acid $(55 \mu \mathrm{M})$; Hydro: hydrophilic tomato ketchup extract; Lipo: lipophilic tomato ketchup extract. 


\subsection{Discussion}

Prolonged, low grade inflammation disturbs homeostasis and has been implicated in the etiology of chronic diseases such as atherosclerosis (1, 2, 5, 32). Fast-food and unbalanced diets increase the risk for cardiovascular diseases $(33,34)$. Evidence is accumulating that fruits and vegetables provide substantial health benefits, especially against these chronic diseases (3538). It has been reported that tomatoes and tomato products exert anti-inflammatory effects $(1,32,39)$. In the US the frequent tomato ketchup consumption among people aged between 15-35 years is responsible for their relatively high lycopene intake (40). This prompted us to investigate the effect of tomato ketchup on the three phases (i.e. gene expression, cytokine release and chemotaxis) of the inflammatory process. Interestingly, a consistent inhibitory effect of tomato ketchup extracts on various phases of the inflammatory process was observed.

We assessed the activity of $N F \kappa B$ via the expression of the inhibitor of IKB gene. IKB gene expression is directly related to NFKB activation (4, 41-43). The lower I $\kappa B$ gene expression indicated that tomato ketchup extract attenuated the initial phase of the inflammation process by reducing the activity of the transcription factor $\mathrm{NFKB}$. Of the extracts and compounds tested, the hydrophilic extract had a relatively low anti-inflammatory potency and even displayed some pro-inflammatory activity. The sugar in tomato ketchup might be involved in the observed slightly increased IKB expression by the hydrophilic extract. It appeared that the lipophilic extract most effectively inhibited the expression of $\mathrm{I \kappa B}$ (figure 2 ).

The effect on IKB gene expression was consistent with the observed inhibition on gene expression of the pro-inflammatory cytokines TNF- $\alpha$ and IL- 8 by tomato ketchup which is controlled by NFKB. In line with the reduced gene expression, the release of TNF- $\alpha$ and IL- 8 was inhibited with $61 \pm 9 \%$ and $69 \pm 4 \%$, respectively, by the tomato ketchup extracts. Of the bio-active compounds tested, lycopene was found to be the most effective.

TNF- $\alpha$ incites the inflammatory process by a stimulating feedback since TNF- $\alpha$ itself can activate $\mathrm{NFKB}(4,44)$. NFKB activation increases TNF- $\alpha$ release which further amplifies the inflammatory process. The inhibitory effect of tomato ketchup extracts on TNF- $\alpha$ release is expected to contribute to a reduced activation of NFKB. In this way, inflammation would be mitigated at an early phase by tomato ketchup and further amplification of the process is prevented.

During inflammation also negative feedback loops are activated by stimulating the production of anti-inflammatory cytokines such as IL-4, IL-10 and IL-13 (5). Tomato ketchup extracts appeared to increase IL-10 production, indicating stimulation of the negative feedback mechanism. The effect of tomato ketchup extracts on the protein production of IL-10 was relatively high and did not correlate with its gene expression/while its gene expression remained unaf- 
fected. This might suggest that tomato ketchup extracts affects the anti-inflammatory feedback control by IL-10 via another mechanism than its gene expression.

There was a good correlation between the gene-expression and cytokine production of TNF$\alpha$ and IL-8 (figure 1). This suggests that modulating gene-expression is involved in the reduction of the production of these pro-inflammatory cytokines by tomato ketchup extracts. Apparently, the anti-inflammatory effect of tomato ketchup extracts is achieved via different molecular modes of actions. These results also indicate that tomato ketchup mitigates inflammation in this early phase in two distinct pathways i.e. by inhibiting the pro-inflammatory positive feedback and by stimulating the anti-inflammatory feedback mechanism. In both effects, lycopene again seems to be the most effective compound.

A crucial phase of the inflammatory process is the migration of monocytes from the vascular lumen into the vascular wall. This process, known as chemotaxis $(5,6,8)$ consists of sequential interactions between monocytes and endothelial cells. Firstly, endothelial cells are triggered by chemotactic factors (e.g. IL-8) to express adhesion molecules such as E-selectin and ICAM1 (7). Consistent with the inhibition of IL-8 release, our results showed that tomato ketchup reduced the expression of E-selectin and ICAM-1 (figure 3). After the monocytes adhere to the adhesion molecules on the endothelium, the monocytes migrate to the inflamed site, which is initiated by a concentration gradient of a chemotactic factor such as IL-8 (7). In this study the culture medium of inflammatory challenged endothelial cells, which released IL-8, was used in a bioassay for the determination of monocytes chemotaxis. The culture medium of tomato ketchup extract treated endothelial cells reduced the chemotaxis of human monocytes effectively, by $69 \pm 4 \%$. The reduced chemotaxis correlated significantly with the decreased concentration of IL- 8 in the medium that originated from the cultured endothelial cells (figure 4). These observations demonstrate the potential of tomato ketchup to avert chemotaxis.

Tomato ketchup is a mixture in which lycopene, $\alpha$-tocopherol and ascorbate are the most studied ingredients. It contains also numerous other bio-active compounds e.g. carotenoids other than lycopene and flavonoids. Our results consistently underline the contribution of lycopene to the anti-inflammatory effect of tomato ketchup. $\alpha$-Tocopherol and ascorbic acid appeared to strengthen the anti-inflammatory effect of lycopene. These findings are in line with our previous results which also indicate that the inflammatory process was mitigated by especially lycopene, and that a combination of $\alpha$-tocopherol and ascorbic acid synergistically prevented against oxidative damage (23). Together these compounds act on different levels within the inflammatory process which complements their protective potential against inflammation (23). In the present study, it was observed that the mixture of lycopene, $\alpha$-tocopherol and ascorbic acid extensively inhibited chemotaxis of monocytes. However, the inhibitory effect of tomato ketchup appeared to be even more potent, demonstrating that 
compounds not identified in the present study also contribute to the anti-inflammatory effect of tomato ketchup.

Evidence on the anti-inflammatory properties of tomato ketchup is scarce. To our knowledge this is the first study that addresses this subject on the various phases of the inflammatory process in a structured and detailed approach. The effects of lycopene are much better documented than the effects of tomato products. The anti-inflammatory potential of lycopene is confirmed in the study of Hung et al. who reported that lycopene treatment of endothelial cells significantly inhibited NFKB activation and expression of ICAM-1 (24). Both Feng et al.(45) and Palozza et al. (21) showed that lycopene attenuated IאB phosphorylation in macrophages. Additionally, lycopene also effectively reduced the production of pro-inflammatory cytokines in vitro $(21,45)$. In line with previous observations, our study also indicates that lycopene plays an essential role in the anti-inflammatory effects of tomato ketchup $(1,2,12,14,46)$.

Moreover, the results of the present study draw attention to the importance of compounds in tomato ketchup other than lycopene. The anti-inflammatory effects of tomatoes and tomato products have also been studied in clinical settings $(10,13,46,47)$. In the study of Sanchez-Moreno et al. the effect of gazpacho, a vegetable soup containing high levels of tomatoes, on pro-inflammatory mediators in healthy volunteers was examined. It was found that the combination of various bio-active compounds in this soup protected against oxidative stress and inflammation by reducing the generation of prostaglandins and chemoattractants (10). Blum et al. did not observe an anti-inflammatory effect after the consumption of a tomato rich diet in healthy volunteers (25). However, in the study of Riso et al. the production and release of the pro-inflammatory cytokine TNF- $\alpha$ was effectively reduced after the consumption of tomato-juice (13). Similarly, Markovits et al. reported that supplementation of tomato derived lycopene, attenuated pro-inflammatory markers including TNF- $\alpha$, IL- 6 and $\mathrm{C}$-reactive protein in obese patients (39). The majority of studies that investigated the effects of tomato products concluded that the participation of bio-active compounds other than lycopene, also contributed to the observed health effects (10, 11, 48).

The findings of the present study highlight the anti-inflammatory potential of tomato ketchup extracts. The effects on specific pathways appear to be relatively subtle and will not result in a complete block of the individual phases of the inflammatory process. Nevertheless, tomato ketchup extracts appears to interfere on several levels, including early phases in which it inhibits the positive feedback and stimulates the negative feedback of the inflammatory process. This is integrated in a clear inhibitory effect on chemotaxis. Such a pleotropic mode of action can especially be effective in mitigation of prolonged, low-grade inflammation. Based on the results of the current study, tomato ketchup seems to have the potential to preserve health, which deserves further attention. 


\section{References}

1. Palozza P, Parrone N, Simone RE, Catalano A (2010) Lycopene in atherosclerosis prevention: an integrated scheme of the potential mechanisms of action from cell culture studies. Arch Biochem Biophys 504: 26-33.

2. Palozza P, Parrone N, Simone R, Catalano A (2011) Role of Lycopene in the Control of ROS-Mediated Cell Growth: Implications in Cancer Prevention. Curr Med Chem 18: 1846-1860.

3. Weber C, Noels H (2011) Atherosclerosis: current pathogenesis and therapeutic options. Nat Med 17: 1410-1422.

4. Hayden MS, West AP, Ghosh S (2006) NF-kappaB and the immune response. Oncogene 25: 6758-6780.

5. Galkina E, Ley K (2009) Immune and inflammatory mechanisms of atherosclerosis (*). Annu Rev Immunol 27: 165-197.

6. Soehnlein O, Lindbom L, Weber C (2009) Mechanisms underlying neutrophil-mediated monocyte recruitment. Blood 114: 4613-4623.

7. Martin J, Collot-Teixeira S, McGregor L, McGregor JL (2007) The dialogue between endothelial cells and monocytes/macrophages in vascular syndromes. Curr Pharm Des 13: 1751-1759.

8. Wang Y, Chen CL, lijima M (2011) Signaling mechanisms for chemotaxis. Dev Growth Differ 53: 495-502.

9. Galkina E, Ley K (2007) Vascular adhesion molecules in atherosclerosis. Arterioscler Thromb Vasc Biol 27: 2292-2301.

10. Sanchez-Moreno C, Cano MP, de Ancos B, Plaza L, Olmedilla B, et al. (2006) Mediterranean vegetable soup consumption increases plasma vitamin $\mathrm{C}$ and decreases $\mathrm{F}_{2}$-isoprostanes, prostaglandin $\mathrm{E}_{2}$ and monocyte chemotactic protein-1 in healthy humans. J Nutr Biochem 17: 183-189.

11. Jacob K, Periago MJ, Bohm V, Berruezo GR (2008) Influence of lycopene and vitamin C from tomato juice on biomarkers of oxidative stress and inflammation. Br J Nutr 99: 137-146.

12. Palozza P, Parrone N, Catalano A, Simone R (2010) Tomato lycopene and inflammatory cascade: basic interactions and clinical implications. Curr Med Chem 17: 2547-2563.

13. Riso P, Visioli F, Grande S, Guarnieri S, Gardana C, et al. (2006) Effect of a tomato-based drink on markers of inflammation, immunomodulation, and oxidative stress. J Agric Food Chem 54: 2563-2566.

14. Frusciante L, Carli P, Ercolano MR, Pernice R, Di Matteo A, et al. (2007) Antioxidant nutritional quality of tomato. Mol Nutr Food Res 51: 609-617.

15. Niki E (1987) Antioxidants in relation to lipid peroxidation. Chem Phys Lipids 44: 227-253.

16. Niki E (1987) Interaction of ascorbate and alpha-tocopherol. Ann N Y Acad Sci 498: 186-199.

17. van Haaften RI, Evelo CT, Haenen GR, Bast A (2001) alpha-Tocopherol inhibits human glutathione S-transferase pi. Biochem Biophys Res Commun 280: 631-633.

18. Roberts LJ, 2nd, Oates JA, Linton MF, Fazio S, Meador BP, et al. (2007) The relationship between dose of vitamin E and suppression of oxidative stress in humans. Free Radic Biol Med 43: 1388-1393.

19. Christman JW, Blackwell TS, Juurlink BH (2000) Redox regulation of nuclear factor kappa B: therapeutic potential for attenuating inflammatory responses. Brain Pathol 10: 153-162. 
20. Palozza P, Simone R, Catalano A, Monego G, Barini A, et al. (2011) Lycopene prevention of oxysterol-induced proinflammatory cytokine cascade in human macrophages: inhibition of NF-kappaB nuclear binding and increase in PPARgamma expression. J Nutr Biochem 22: 259-268.

21. Simone RE, Russo M, Catalano A, Monego G, Froehlich K, et al. (2011) Lycopene inhibits NF-kB-mediated IL-8 expression and changes redox and PPARgamma signalling in cigarette smoke-stimulated macrophages. PLoS One 6: e19652.

22. Bast MHGRMMHARWA (2012) The anti-inflammatory effect of lycopene complements the antioxidant action of ascorbic acid and $\alpha$-tocopherol. Food Chemistry 132: 954-958.

23. Hung CF, Huang TF, Chen BH, Shieh JM, Wu PH, et al. (2008) Lycopene inhibits TNF-alpha-induced endothelial ICAM-1 expression and monocyte-endothelial adhesion. Eur J Pharmacol 586: 275-282.

24. Blum A, Monir M, Khazim K, Peleg A, Blum N (2007) Tomato-rich (Mediterranean) diet does not modify inflammatory markers. Clin Invest Med 30: E70-74.

25. Agarwal A, Shen H, Agarwal S, Rao AV (2001) Lycopene Content of Tomato Products: Its Stability, Bioavailability and In Vivo Antioxidant Properties. J Med Food 4: 9-15.

26. Mackinnon ES, Rao AV, Rao LG (2009) Lycopene intake by Canadian women is variable, similar among different ages, but greater than that reported for women in other countries. J Med Food 12: 829-835.

27. Re R, Mishra GD, Thane CW, Bates CJ (2003) Tomato consumption and plasma lycopene concentration in people aged $65 \mathrm{y}$ and over in a British national survey. Eur J Clin Nutr 57: 1545-1554.

28. Livak KJ, Schmittgen TD (2001) Analysis of relative gene expression data using real-time quantitative PCR and the 2(-Delta Delta C(T)) Method. Methods 25: 402-408.

29. Yang YY, Hu CJ, Chang SM, Tai TY, Leu SJ (2004) Aspirin inhibits monocyte chemoattractant protein-1 and interleukin-8 expression in TNF-alpha stimulated human umbilical vein endothelial cells.

Atherosclerosis 174: 207-213.

30. Denton CP, Shi-Wen X, Sutton A, Abraham DJ, Black CM, et al. (1998) Scleroderma fibroblasts promote migration of mononuclear leucocytes across endothelial cell monolayers. Clin Exp Immunol 114: 293-300.

31. Rao AV (2002) Lycopene, tomatoes, and the prevention of coronary heart disease. Exp Biol Med (Maywood) 227: $908-913$.

32. Cascio G, Schiera G, Di Liegro I (2012) Dietary Fatty acids in metabolic syndrome, diabetes and cardiovascular diseases. Curr Diabetes Rev 8: 2-17.

33. Riccardi G, Giacco R, Rivellese AA (2004) Dietary fat, insulin sensitivity and the metabolic syndrome. Clin Nutr 23: 447-456.

34. Gil A, Ortega RM, Maldonado J (2011) Wholegrain cereals and bread: a duet of the Mediterranean diet for the prevention of chronic diseases. Public Health Nutr 14: 2316-2322.

35. Esfahani A, Wong JM, Truan J, Villa CR, Mirrahimi A, et al. (2011) Health effects of mixed fruit and vegetable concentrates: a systematic review of the clinical interventions. J Am Coll Nutr 30: 285-294.

36. Minorsky PV (2002) Lycopene and human health. Plant Physiol 130: 1077-1078.

37. Weisburger JH (1999) Mechanisms of action of antioxidants as exemplified in vegetables, tomatoes and tea. Food Chem Toxicol 37: 943-948. 
38. Markovits N, Ben Amotz A, Levy Y (2009) The effect of tomato-derived lycopene on low carotenoids and enhanced systemic inflammation and oxidation in severe obesity. Isr Med Assoc J 11: 598-601.

39. Blackwell TS, Christman JW (1997) The role of nuclear factor-kappa B in cytokine gene regulation. Am J Respir Cell Mol Biol 17: 3-9.

40. Geraets L, Moonen HJ, Brauers K, Gottschalk RW, Wouters EF, et al. (2007) Flavone as PARP-1 inhibitor: its effect on lipopolysaccharide induced gene-expression. Eur J Pharmacol 573: 241-248.

41. Perez P, Lira SA, Bravo R (1995) Overexpression of RelA in transgenic mouse thymocytes: specific increase in levels of the inhibitor protein I kappa B alpha. Mol Cell Biol 15: 3523-3530.

42. Rao P, Hayden MS, Long M, Scott ML, West AP, et al. (2010) IkappaBbeta acts to inhibit and activate gene expression during the inflammatory response. Nature 466: 1115-1119.

43. Feng D, Ling WH, Duan RD (2010) Lycopene suppresses LPS-induced NO and IL-6 production by inhibiting the activation of ERK, P38MAPK, and NF-kappaB in macrophages. Inflamm Res 59: 115-121.

44. Canene-Adams K, Campbell JK, Zaripheh S, Jeffery EH, Erdman JW, Jr. (2005) The tomato as a functional food. J Nutr 135: 1226-1230.

45. Ellinger S, Ellinger J, Muller SC, Stehle P (2009) [Tomatoes and lycopene in prevention and therapy-is there an evidence for prostate diseases?]. Aktuelle Urol 40: 37-43.

46. Bose KS, Agrawal BK (2007) Effect of lycopene from tomatoes (cooked) on plasma antioxidant enzymes, lipid peroxidation rate and lipid profile in grade-I hypertension. Ann Nutr Metab 51: 477-481. 
Cook, if you hod one shot, one opportunity To seise everything you ever wonted in one moment Would you copture it or just let it slip?

You better lose yourself in the music, the moment Kow own it, you better never let it go Cow only get one shot, do not miss your chance to blow This opportunity comes once in a lifetime

You con do onything you set your mind to, mon 

The protective potential of tomato ketchup consumption on inflammation induced ex-vivo in human blood

Merel Hazewindus

Guido R.M.M. Haenen

Antje R. Weseler

Aalt Bast 


\begin{abstract}
Energy dense foods challenge homeostasis and contribute to the development of the cardio metabolic syndrome. This condition is characterized by chronic inflammation. The consumption of tomato products has been associated with a decreased risk for chronic inflammatory diseases. In this study, the effect of a single consumption of tomato ketchup on cytokine production in healthy volunteers was determined. In a functional bioassay for chemotaxis, the ability to adapt to an external inflammatory challenge (i.e. LPS) in these subjects was assessed. Our experiments showed that tomato ketchup consumption effectively reduced TNF- $\alpha$ production and a trend was observed for IL-8 inhibition, while tomato ketchup did not alter IL10 release. The individual cytokines are only a small part of the inflammatory process. The effect was more pronounced on monocyte migration, tested in a functional chemotaxis bioassay. This bioassay covers an entire inflammatory process in which the action of the inflammatory challenged blood (ex-vivo) of the healthy volunteers on cultured monocytes are integrated. This functional chemotaxis bioassay could reveal that in healthy volunteers a single tomato ketchup consumption reduces the response to an inflammatory challenge. This points to an improved ability to maintain homeostasis, which uncovers the health potential of tomato ketchup.
\end{abstract}




\subsection{Introduction}

Health has been defined as the absence of disease, but the concept of health is subject to change. In 1946 the World Health Organization (WHO) extended the definition of health to a complete state of physical, mental and social well-being (1). Nowadays the concept of health not only comprises a static healthy condition, it also incorporates on the ability to adapt to external challenges in order to maintain a well balanced homeostasis (2).

Energy dense foods contain high levels of fat, salt and sugar, and can be seen as an external challenge to this homeostasis and their unrestricted long term intake inevitably leads to a condition known as the cardiometabolic syndrome $(3,4)$. The cardiometabolic syndrome predisposes to a cluster of diseases including dyslipidemia, type II diabetes mellitus and hypertension $(3,5)$. Persistent low grade inflammation is a major concern in these conditions and undermines the body's ability to adapt.

While some substances in foods challenge homeostasis, other ingredients such as carotenoids and vitamins support the physiological buffering capacity thereby increasing the ability to adapt (6-10). For instance, tomatoes and tomato products are full of phytochemicals, such as lycopene, ascorbic acid and $\alpha$-tocopherol $(8,10)$. A number of studies report that regular consumption of tomato products (e.g. drinks and paste) reduced inflammatory bio-markers in healthy volunteers (11-13), although sometimes no effect was observed (14, 15). Additionally, it was reported that tomato ketchup and its main constituents, lycopene, ascorbic acid and $\alpha$-tocopherol, mitigated the inflammatory process in vitro (16). The observed effects were subtle but consistently distributed along the various separate processes of inflammation. A key process is the chemotaxis cascade which is controlled by an intricate network of inflammatory mediators, including cytokines and adhesion molecules, that results in monocyte migration (17, 18). In a functional bioassay for chemotaxis, a clear anti-inflammatory effect of tomato ketchup was observed. This demonstrated the multifaceted effect of tomato ketchup on a whole process in which several inflammatory mediators are integrated (19). In the present study, we further examined the effect of tomato ketchup. The effect of a single consumption of tomato ketchup on cytokine production in healthy volunteers was determined. The ability to adapt to an external inflammatory challenge (i.e. LPS) in these subjects was assessed with a functional bioassay for chemotaxis, which enabled us to estimate the potential health benefit of tomato ketchup. 


\subsection{Materials and methods}

\subsubsection{Chemicals}

Tomato ketchup was a gift from H.J. Heinz Company. Human TNF- $\alpha$ ( $7300 \mathrm{pg} / \mathrm{mL})$, and human IL-8 (10 ng/ml) and human IL-10 (4000 pg/mL) were acquired from CLB/Sanquin (The Netherlands). Lipopolysaccaride (LPS, E. coli) were purchased from Sigma Chemical Co. (USA). All other chemicals were of analytical grade.

\subsubsection{Cell culture}

Human monocytes U937 (CRL-1593.2; American Type Cell Culture, USA) were cultured in RPMI-1640 culture medium containing $200 \mathrm{mg} / \mathrm{L} \mathrm{I-glutamine}$ and $25 \mathrm{mM} \mathrm{HEPES} \mathrm{(Gibco,} \mathrm{UK),}$ supplemented with 100 units $/ \mathrm{ml}$ penicillin (Gibco, UK), $100 \mu \mathrm{g} / \mathrm{ml}$ streptomycin (Gibco, UK), $10 \%$ heat inactivated fetal calf serum (Gibco, UK) in a $5 \% \mathrm{CO}_{2}$ incubator at $37^{\circ} \mathrm{C}$.

\subsubsection{Subjects}

Six healthy male subjects were recruited for the study. No users of any medication participated in the study. Blood donation three months before the start of the study, consumption of three glasses or more of alcohol per day, vegetarian lifestyle or allergies to food components were exclusion criteria in the recruitment. The volunteers were informed of the purposes and risks of the study, and written informed consent was obtained. The study was approved by the Medical Ethics Committee of the Maastricht Academic Hospital and Maastricht University (reference MEC 11-3-049.3; NCT 01462825).

\subsubsection{Test meals}

For the study, a control meal and a tomato ketchup meal were prepared. The control meal consisted of $200 \mathrm{~g}$ white cooked rice with a vinaigrette providing comparable amounts of sugar, fat and vinegar to the tomato ketchup meal (table 1). The control meal did not contain any of the antioxidants of interest and consisted of approximately $2060 \mathrm{~kJ}$ (492 kcal). The tomato ketchup meal consisted of $200 \mathrm{~g}$ white cooked rice and $200 \mathrm{~g}$ tomato ketchup containing approximately $30 \mathrm{mg}$ lycopene. All ingredients used were safe for human consumption and commercially available. 
Table 1. Macronutrient composition of the vinaigrette (control meal) and tomato ketchup consumed by the participants in the study

\begin{tabular}{ll} 
g/loo g & \\
Total carbohydrates & 21.61 \\
Fat & 0.35 \\
Protein & 1.43 \\
Salt based on $\mathrm{Na}$ & 3.05 \\
Salt based on $\mathrm{Cl}$ & 3.09 \\
\hline
\end{tabular}

Table 2. Lycopene, $\alpha$-tocopherol and ascorbic acid composition of the tomato ketchup consumed by the participants in the study

\begin{tabular}{lr}
\hline g/100 g & \\
Lycopene & $1.87 \mathrm{mg}$ \\
$\alpha$-Tocopherol & $16.30 \mathrm{mg}$ \\
Ascorbic acid & $94.40 \mathrm{mg}$
\end{tabular}

\subsubsection{Study design}

The study was a placebo controlled cross-over design. The study design was not blinded since this was practically impossible because of the taste and appearance of the tomato ketchup. This did not affect the outcome of the study since the endpoints which were used were based on chemical assays. Standard operating procedures were prepared before the start of the study and the assays were performed blind. Three days prior to the first intervention day, the participants were instructed not to consume any tomato or tomato products, nuts and seeds, antioxidant supplements or beverages high in antioxidants or antioxidant rich food (fruit and vegetables) and to record their food and beverage intake during these three days. The volunteers received a standardized low-antioxidant meal consisting of wheat noodles the evening prior to the first intervention day. After an overnight fast, the participants consumed the control meal in the morning and received a standardized lunch and dinner low in antioxidants. After a second overnight fast the volunteers consumed a tomato ketchup meal in the morning of the second intervention day. During both intervention days, only drinking water (ad libitum) was allowed. Blood was collected six hours after the consumption of each the intervention meals (14.30 - 15.00 a.m.) (figure 1). 
Figure 1. outline of the study

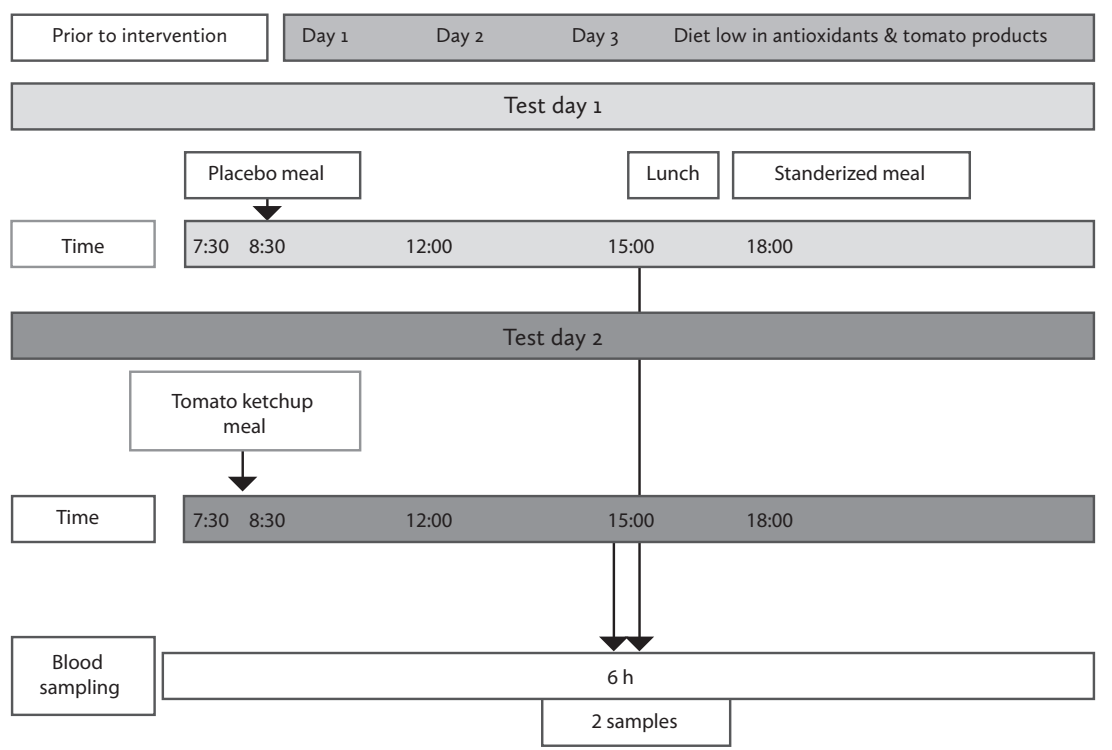




\subsubsection{Ex vivo induced inflammatory response}

Blood was collected six hours after the consumption of the test meals and diluted with RPMI1640 culture medium in a 1:4 ratio. LPS (from Escherichia coli) was added to a final concentration of $100 \mathrm{ng} / \mathrm{ml}$ and the blood samples were incubated in triplicate for 6 or $24 \mathrm{~h}$ at $37^{\circ} \mathrm{C}$ and $5 \% \mathrm{CO}_{2}$ in a humidified atmosphere. After incubation, the supernatants obtained by centrifugation ( $1000 \mathrm{~g}$ for $5 \mathrm{~min}$ at $4{ }^{\circ} \mathrm{C}$ ) were used immediately to determine chemotaxis or stored at $-80{ }^{\circ} \mathrm{C}$ until analysis. For the cytokine analyses (TNF- $\alpha$, IL-8 and IL-10) human cytokine kits from CLB/Sanquin (Netherlands) were used following the instructions of the manufacturer. For each subject, the cytokine expression (average of triplicate determination) was related to that in the LPS-stimulated blood.

\subsubsection{Chemotaxis bio-assay}

The chemotaxis assay was adapted from $(20,21)$ with minor modifications. Briefly the supernatant of the stimulated blood (100 $\mathrm{ng} / \mathrm{ml}$ LPS, $24 \mathrm{~h}$ ) was obtained by centrifugation (1000 $\mathrm{g}$ for $5 \mathrm{~min}$ at $\left.4{ }^{\circ} \mathrm{C}\right)$ and transferred $(800 \mu \mathrm{l})$ into the lower chamber of a transwell insert $(5 \mu \mathrm{M}$ pore size, Costar, USA). Cultured U937 cells were added to the upper chamber $\left(10^{6} \mathrm{cells} / \mathrm{ml}\right.$ ) and allowed to migrate through the polycarbonate membrane at $37^{\circ} \mathrm{C}, 5 \% \mathrm{CO}_{2}$. After $90 \mathrm{~min}$ the cells in the lower wells were collected by centrifugation at $3000 \mathrm{x}$ for $5 \mathrm{~min}$ and directly counted under a microscope. For each subject, the cell count (average of triplicate determination) was related to that in the LPS-stimulated blood.

\subsubsection{Statistical analysis}

All experiments were performed, at least, in triplicate. Results are given as mean \pm s.d. The statistical significance of the differences between the effect of the tomato ketchup meal and the control meal on inflammation in ex-vivo stimulated blood were compared. The statistical significance was determined by a paired Student's $t$-test. P-values $\leq 0.05$ were considered statistically significant. 
Figure 2. The effect of the control meal and the tomato ketchup meal on cytokine production in human blood by a LPS challenge.

94
$n$
$I$
$>$
0
-1
$m$
0
$a$

A
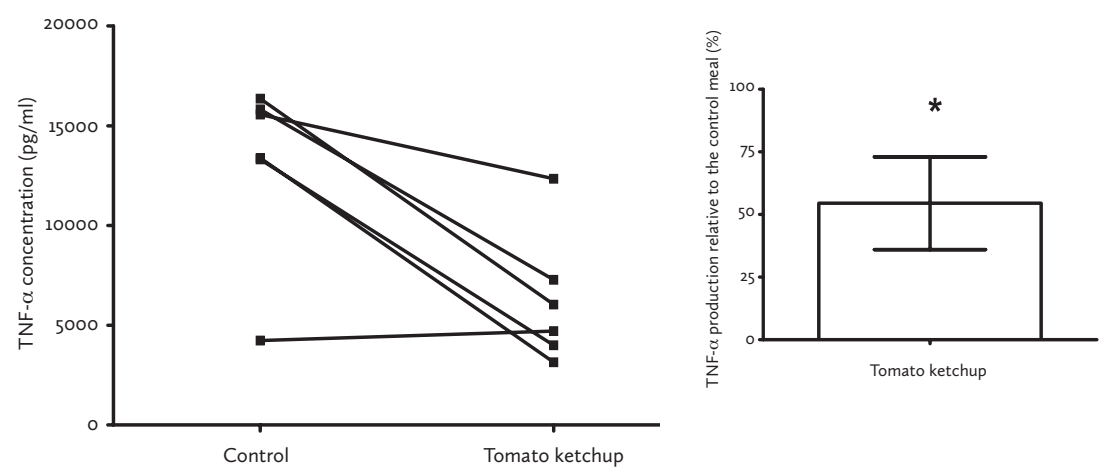

B
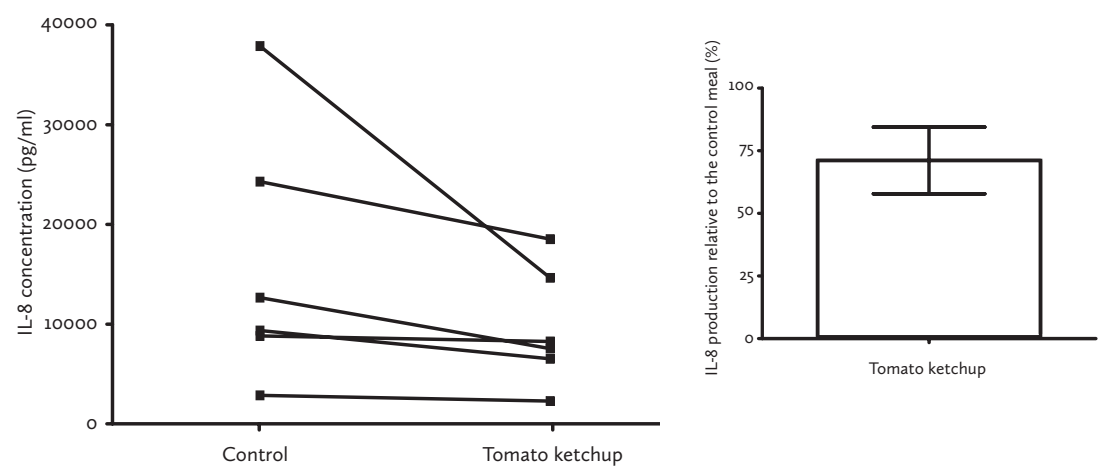

C
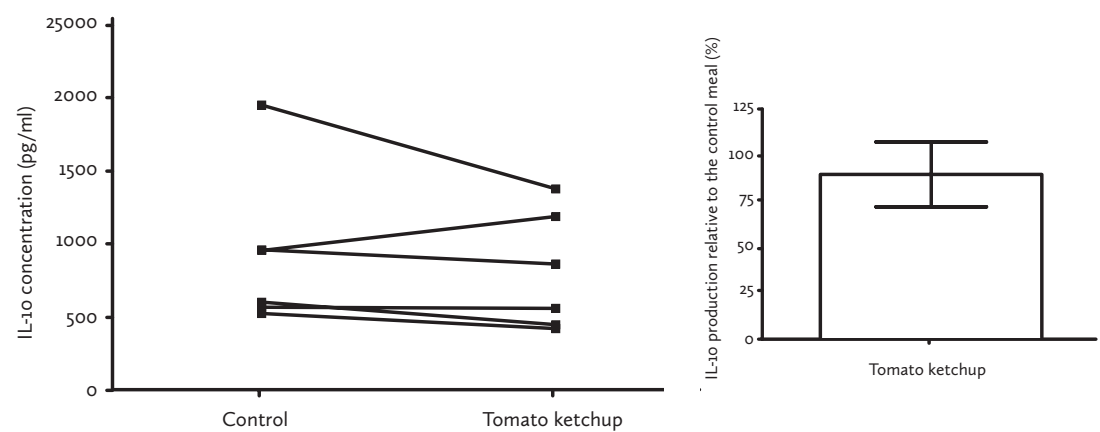

Panel A: TNF- $\alpha$ inhibition. * Tomato ketchup significantly inhibited the production of TNF- $\alpha$ in human blood. Panel B: IL-8 inhibition.

Panel C: IL-10 stimulation. The relative cytokine production after the consumption of the tomato ketchup meal is depicted as inset.

Human blood was challenged with LPS (100 ng/ml) for 6 (TNF- $\alpha$ ) or $24 \mathrm{~h}(\mathrm{IL}-8, \mathrm{IL}-10)$. Data are presented as mean \pm sem $* \mathrm{p} \leq 0.05$ significantly lower than the control meal. 


\subsection{Results}

\subsubsection{Cytokine production}

TNF- $\alpha$ production in blood after a LPS challenge was reduced ( $46 \pm 9 \% ; p=0.01$ ) after the consumption of the tomato ketchup meal (figure $2 \mathrm{~A}$ ). Tomato ketchup consumption tended to reduce the production of IL- 8 with $31 \pm 8 \%(p=0.06)$ (figure $2 \mathrm{~B})$. The anti-inflammatory cytokine IL-10 was not stimulated by tomato ketchup (figure $2 \mathrm{C}$ ).

Table 3. Characteristics of the subjects

\begin{tabular}{lr}
\hline Characteristics & \\
Age $(\mathrm{y})$ & $33 \pm 4.2$ \\
Height $(\mathrm{cm})$ & $184 \pm 2.2$ \\
Weight $(\mathrm{kg})$ & $86 \pm 2.9$ \\
BMI $(\mathrm{kg} / \mathrm{m} 2)$ & $26 \pm 0.6$ \\
\hline
\end{tabular}

Values are mean \pm sem; $n=6$

\subsubsection{Chemotaxis}

The bioassay for chemotaxis was assessed with the supernatant of the blood of the healthy volunteers and cultured human monocytes. Tomato ketchup significantly reduced the migration of monocytes ( $27 \pm 7 \%$; $=0.006$ ) in the challenged blood (with LPS; $100 \mathrm{ng} / \mathrm{ml}$ ) (figure 3 ). In unchallenged blood tomato ketchup consumption did not affect monocyte migration (data not shown). 

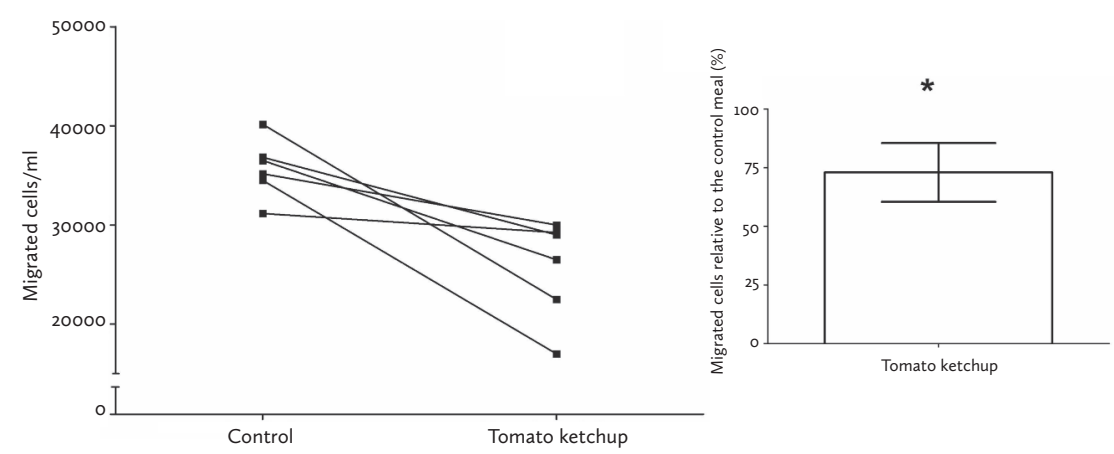

Migration of human monocytes triggered by LPS stimulated human blood. * Tomato ketchup significantly inhibited the migration of human monocytes. The relative inhibition of monocyte migration after the consumption of the tomato ketchup meal is depicted as inset. The medium and supernatant of LPS (100 ng/ml) stimulated human blood ( $24 \mathrm{~h}$ ) was used for the migration ( $90 \mathrm{~min}$ ) of human monocytes (cells $/ \mathrm{ml}$ ).Data are presented as mean \pm sem. $* \mathrm{p} \leq 0.05$ significantly lower than the control meal.

Figure 4. The effect of tomato ketchup on the chemotaxis cascade

$+$
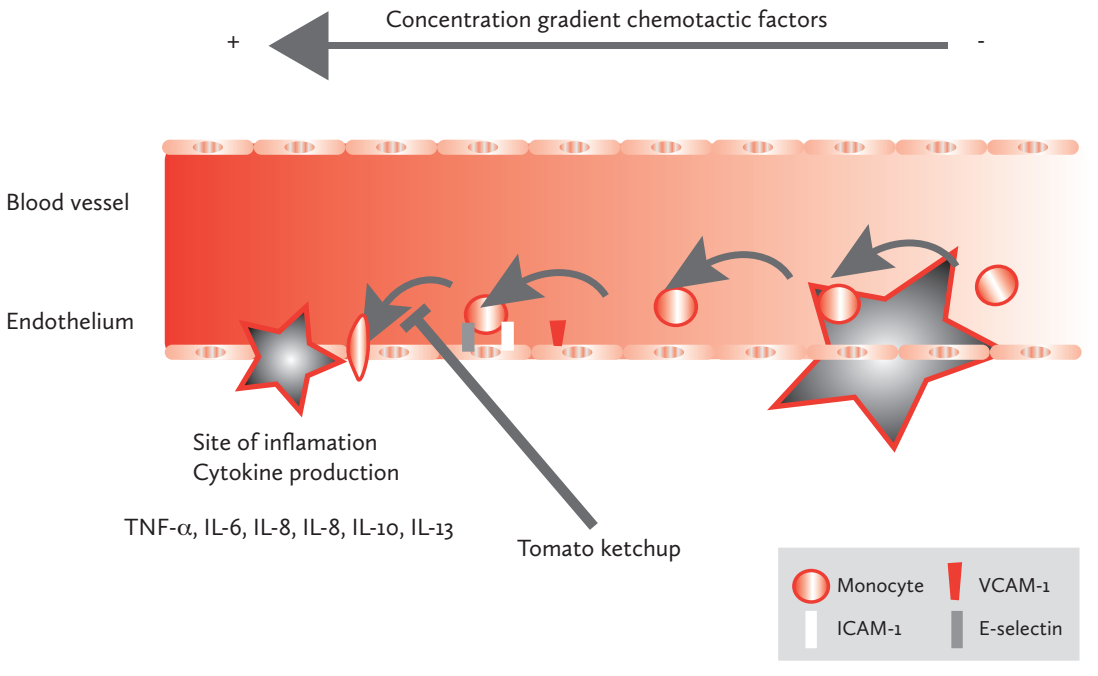

At the site of inflammation, TNF- $\alpha$ and chemotactic factors (IL- 8 and MCP-1) are released to recruit monocytes. As the monocytes are recruited,also the expression of adhesion molecules at the endothelium (ICAM1, VCAM-1, E-selectin) is increased. The monocytes firmly adhere to these adhesion molecules triggering the monocytes to migrate through the endothelium. The migration of monocytes leads to the production of more cytokines which amplify the chemotaxis cascade. Tomato ketchup consumption reduces chemotaxis. TNF- $\alpha$ : tumor necrosis factor- $\alpha$; MCP-1: monocyte chemotactic protein-1; VCAM-1: vascular cell adhesion molecule-1; ICAM-1:intercellular cell adhesion molecule-1. 


\subsection{Discussion}

During the past decades the incidence of diet related diseases has considerably increased $(3,5)$. Energy dense foods challenge homeostasis and contribute to the development of the cardiometabolic syndrome. The cardiometabolic syndrome predisposes to cardiovascular diseases, type II diabetes mellitus and hypertension. These conditions are characterized by persistent low grade inflammation $(3,5,22)$. Chronic inflammation is associated with increased levels of multiple inflammatory mediators, including cytokines (e.g. TNF- $\alpha$, IL-6, IL-10), adhesion molecules (e.g. ICAM-1, E-selectin) and chemotactic factors (e.g. MCP-1, IL-8) (23-25). In the present study the effect of a single consumption of tomato ketchup was determined on the individual inflammatory markers TNF- $\alpha$, IL- 8 and IL-10 in blood from healthy volunteers upon addition of LPS ex vivo. TNF- $\alpha$ production was reduced and a trend was observed for IL-8 inhibition, while tomato ketchup did not alter IL-10 release (figure 1). The individual cytokines are only a small part of the inflammatory process. In fact, inflammation is a process that consists of several phases in which the effect of a multitude of inflammatory mediators are integrated $(26,27)$. The chemotaxis cascade is key during inflammation $(28-30)$. Chemotaxis is triggered by circulating inflammatory cytokines, like TNF- $\alpha$. Subsequently, monocyte recruitment is initiated by a gradient of chemotactic factors such as IL- 8 and monocyte chemotactic protein-1 (MCP-1) at the site of inflammation. The increased release of chemotactic factors stimulates the endothelium to express adhesion molecules (e.g. ICAM-1, VCAM-1,Eselecetin), to which monocytes firmly adhere and subsequently migrate through the vascular wall (figure 3). Migrated monocytes perturb the homeostasis in the intima of a blood vessels which poses a threat to cardiovascular health $(17,28)$.

Evidence is accumulating that foods rich in carotenoids, vitamins and polyphenols contribute to health by attenuating the inflammatory process (31-33). Tomato ketchup contains various of those compounds such as lycopene, $\beta$-carotene, ascorbic acid and $\alpha$-tocopherol (8). Recently, we reported that in vitro tomato ketchup exerted anti-inflammatory effects in a multifaceted manner (19). Tomato ketchup inhibited individual inflammatory mediators playing an important role in the chemotaxis cascade (TNF- $\alpha$, IL-8, E-selectin and ICAM-1). The effect was more pronounced on monocyte migration, tested in a functional chemotaxis bioassay. This bioassay covers an entire inflammatory process in which the action of inflammatory mediators on monocytes are integrated, and mimics a pivotal patho-physiological process. This not only improves the sensitivity of the assay, it also facilitates extrapolation of the results to in vivo conditions.

In this study the chemotaxis bio-assay was used to estimate the health potential, i.e. the buffering capacity of homeostasis in healthy volunteers 'The ability to adapt'. Therefore an 
external challenge was performed by using the pro-inflammatory agent LPS. It was observed that the consumption of tomato ketchup significantly reduced chemotaxis induced by the inflammatory challenge, uncovering the potential of tomato ketchup to improve the ability of the volunteers to adapt. That a clear effect was found, confirms the sensitivity of the chemotaxis bioassay and points at a multifaceted mode of action of the tomato ketchup consumption on the chemotaxis cascade.

The observations of the present study are in line with those of other studies on the anti-inflammation effect of tomato product or tomato extract supplementation. However, differences in tomato product and study design hamper a straightforward comparison. In studies that supplemented healthy subjects with tomato extracts (Lyc-o-Mato), the inflammatory biomarkers TNF- $\alpha$ and C-reactive protein were reduced after several weeks $(12,34)$. Contrastingly, the studies of Blum et al. and Denniss et al. did not observe anti-inflammatory effects after tomato extract supplementation (14). These investigations quantified isolated and single inflammatory endpoints in healthy volunteers, while maintaining homeostasis is integrative and multifactoral. The use of an inflammatory bioassay and the use of a challenge appeared to be sensitive and is relatively directly linked to a potential health effect. This approach seamlessly fits in the contemporary concept of health which also includes the ability of healthy people to maintain homeostasis.

In conclusion, a functional chemotaxis bio-assay could reveal that in healthy volunteers a single tomato ketchup consumption reduces the response to an inflammatory challenge. This points at an improved ability to maintain homeostasis, which uncovers the health potential of tomato ketchup. 


\section{References}

1. (WHO) WHO. Preamble to the Constitution of the World Health Organization as adopted by the International Health Conference. New York, ; Accessed 2012 March 5; 19-22 June 1946, and entered into force on 7 April 1948.

2. van Ommen B, Keijer J, Heil SG, Kaput J. Challenging homeostasis to define biomarkers for nutrition related health. Mol Nutr Food Res. 2009 Jul;53:795-804.

3. Cascio G, Schiera G, Di Liegro I. Dietary Fatty acids in metabolic syndrome, diabetes and cardiovascular diseases. Curr Diabetes Rev. 2012 Jan 1;8:2-17.

4. Riccardi G, Giacco R, Rivellese AA. Dietary fat, insulin sensitivity and the metabolic syndrome. Clin Nutr. 2004 Aug;23:447-56.

5. Ren J, Kelley RO. Cardiac health in women with metabolic syndrome: clinical aspects and pathophysiology. Obesity (Silver Spring). 2009 Jun;17:1114-23.

6. Bohm V. Lycopene and heart health. Mol Nutr Food Res. 2012 Feb;56:296-303.

7. Boots AW, Haenen GR, Bast A. Health effects of quercetin: from antioxidant to nutraceutical. Eur J Pharmacol. 2008 May 13;585:325-37.

8. Frusciante L, Carli P, Ercolano MR, Pernice R, Di Matteo A, Fogliano V, Pellegrini N. Antioxidant nutritional quality of tomato. Mol Nutr Food Res. 2007 May;51:609-17.

9. D’Archivio M, Filesi C, Di Benedetto R, Gargiulo R, Giovannini C, Masella R. Polyphenols, dietary sources and bioavailability. Ann Ist Super Sanita. 2007;43:348-61.

10. Gomez-Romero M, Arraez-Roman D, Segura-Carretero A, Fernandez-Gutierrez A. Analytical determination of antioxidants in tomato: typical components of the Mediterranean diet. J Sep Sci. 2007 Mar;30:452-61.

11. Palozza P, Parrone N, Catalano A, Simone R. Tomato lycopene and inflammatory cascade: basic interactions and clinical implications. Curr Med Chem. 2010;17:2547-63.

12. Riso P, Visioli F, Grande S, Guarnieri S, Gardana C, Simonetti P, Porrini M. Effect of a tomato-based drink on markers of inflammation, immunomodulation, and oxidative stress. J Agric Food Chem. 2006 Apr 5;54:2563-6.

13. Heber D, Lu QY. Overview of mechanisms of action of lycopene. Exp Biol Med (Maywood). 2002 Nov;227:920-3.

14. Denniss SG, Haffner TD, Kroetsch JT, Davidson SR, Rush JW, Hughson RL. Effect of short-term lycopene supplementation and postprandial dyslipidemia on plasma antioxidants and biomarkers of endothelial health in young, healthy individuals. Vasc Health Risk Manag. 2008;4:213-22.

15. Blum A, Monir M, Khazim K, Peleg A, Blum N. Tomato-rich (Mediterranean) diet does not modify inflammatory markers. Clin Invest Med. 2007;30:E70-4.

16. Hazewindus M GRMMH, A.R.Weseler, A.Bast. Protection against chemotaxis in the anti-inflammatory effect of tomato ketchup. Maastricht University; 2012.

17. Noels $\mathrm{H}$, Bernhagen J, Weber C. Macrophage migration inhibitory factor: a noncanonical chemokine important in atherosclerosis. Trends Cardiovasc Med. 2009 Apr;19:76-86.

18. Soehnlein O, Zernecke A, Weber C. Neutrophils launch monocyte extravasation by release of granule proteins. Thromb Haemost. 2009 Aug;102:198-205. 
19. Bast MHGRMMHARWA. The anti-inflammatory effect of lycopene complements the antioxidant action of ascorbic acid and $\alpha$-tocopherol. Food Chemistry. 201215 May 2012;132:954-8.

20. Denton CP, Shi-Wen X, Sutton A, Abraham DJ, Black CM, Pearson JD. Scleroderma fibroblasts promote migration of mononuclear leucocytes across endothelial cell monolayers. Clin Exp Immunol. 1998 Nov;114:293-300.

21. Yang YY, Hu CJ, Chang SM, Tai TY, Leu SJ. Aspirin inhibits monocyte chemoattractant protein-1 and interleukin-8 expression in TNF-alpha stimulated human umbilical vein endothelial cells. Atherosclerosis. 2004 Jun;174:207-13.

22. Grundy SM. Hypertriglyceridemia, insulin resistance, and the metabolic syndrome. Am J Cardiol. 1999 May 13;83:25F-9F.

23. Weber C, Noels H. Atherosclerosis: current pathogenesis and therapeutic options. Nat Med. 2011;17:1410-22.

24. Cottam DR, Mattar SG, Barinas-Mitchell E, Eid G, Kuller L, Kelley DE, Schauer PR. The chronic inflammatory hypothesis for the morbidity associated with morbid obesity: implications and effects of weight loss. Obes Surg. 2004 May;14:589-600.

25. Kundu JK, Surh YJ. Inflammation: gearing the journey to cancer. Mutat Res. 2008 Jul-Aug;659:15-30.

26. Wang Y, Chen CL, lijima M. Signaling mechanisms for chemotaxis. Dev Growth Differ. 2011 May;53:495-502.

27. Galkina E, Ley K. Vascular adhesion molecules in atherosclerosis. Arterioscler Thromb Vasc Biol. 2007 Nov;27:2292-301.

28. Zernecke A, Shagdarsuren E, Weber C. Chemokines in atherosclerosis: an update. Arterioscler Thromb Vasc Biol. 2008 Nov;28:1897-908.

29. Zernecke A, Weber $\mathrm{C}$. Chemokines in the vascular inflammatory response of atherosclerosis. Cardiovasc Res. 2010 May 1;86:192-201.

30. Wong $\mathrm{CH}$, Heit $\mathrm{B}$, Kubes $\mathrm{P}$. Molecular regulators of leucocyte chemotaxis during inflammation. Cardiovasc Res. 2010 May 1;86:183-91.

31. Voutilainen S, Nurmi T, Mursu J, Rissanen TH. Carotenoids and cardiovascular health. Am J Clin Nutr. 2006 Jun;83:1265-71.

32. Gil A, Ortega RM, Maldonado J. Wholegrain cereals and bread: a duet of the Mediterranean diet for the prevention of chronic diseases. Public Health Nutr. 2011 Dec;14:2316-22.

33. Esfahani A, Wong JM, Truan J, Villa CR, Mirrahimi A, Srichaikul K, Kendall CW. Health effects of mixed fruit and vegetable concentrates: a systematic review of the clinical interventions. J Am Coll Nutr. 2011 Oct;30:285-94.

34. Kim JY, Paik JK, Kim OY, Park HW, Lee JH, Jang Y. Effects of lycopene supplementation on oxidative stress and markers of endothelial function in healthy men. Atherosclerosis. 2011 Mar;215:189-95. 
The preatest educotion mon has to learn is the science of self.

YOGI BHAJAN 

CHAPTER 7

General discussion and

future perspectives 


\section{General Discussion}

Chronic inflammation is a complex biological process involving many reactions on cellular and subcellular level such as chemotaxis, cytokine production and gene transcription $(1,2)$. One of the driving forces is the production of reactive oxygen species that damage tissues, cells and molecules, for instance, lipid peroxidation of $\operatorname{LDL}(3,4)$. Upon cell or tissue damage, signaling molecules such as protein kinase $C$ (PKC) are activated (5). PKC activates the transcription factor nuclear factor- $\mathrm{K}-\mathrm{B}(\mathrm{NF \kappa B})$ that initiates the production of pro- inflammatory cytokines, including TNF- $\alpha$ and IL-8 $(6,7)$. High levels of circulating cytokines at the site of inflammation initiate chemotaxis. The process of chemotaxis is orchestrated by an integrated network of inflammatory mediators $(8,9)$. In this process, monocytes are recruited to the inflamed site by chemotactic factors (e.g. IL- 8 and monocyte chemotactic protein-1 (MCP-1)) released from the vascular endothelium. The vascular endothelium expresses adhesion molecules (e.g. inter cellular adhesion molecule-1 (ICAM-1), vascular cell adhesion molecule-1 (VCAM-1), E-selectin), which facilitate monocytes adhesion and migration into the vascular wall $(2,10)$. The migration causes the monocytes to differentiate in macrophages.

Low grade persistent inflammation contributes to the development of cardiovascular diseases (CVD), cancer and osteoporosis (chapter 2) (1, 11-13). Evidence is accumulating that tomatoes have the potential to protect against chronic inflammatory disorders. High intake of tomatoes decreases high blood pressure in animals and humans, and reduces the risk for atherosclerosis (14-16). Moreover, tomatoes have a beneficial effect on bone health in osteoporotic patients $(17,18)$. In addition, tomato rich diets attenuate carcinogenesis, which has been attributed by the interplay of bioactive compounds in tomatoes $(19,20)$.

Health effects of tomatoes have been ascribed to their numerous bioactive compounds, including carotenoids, vitamins and flavonoids (chapter 2). Many studies focused on the effects of isolated tomato bioactives. The carotenoid lycopene is the most studied compound in this respect (11, 21-23). Initially, studies focused on the antioxidant and anti-mutagenic effects of lycopene (24). Recently, it became clear that lycopene has a strong anti-inflammatory potential (23).

Other important bioactive compounds in tomatoes are the vitamins $\alpha$-tocopherol and ascorbic acid. Both vitamins are known for their antioxidant activities. Bioactive compounds in isolation like lycopene, ascorbic acid and $\alpha$-tocopherol do have a protective potential against inflammation. In general, their activity is boosted when bioactives are combined which leads to additive and/ or synergistic interactions (25). An example is the synergistic interaction between ascorbic acid and $\alpha$-tocopherol against lipid peroxidation is well documented (26). 
Knowledge on the interplay between the major bioactive compounds in tomatoes e.g. lycopene, $\alpha$-tocopherol and ascorbic acid is largely lacking. In chapter 3 , the effects of isolated as well as combinations of lycopene, $\alpha$-tocopherol and ascorbic acid on lipid peroxidation and inflammation were examined. The mechanism of the synergistic protection against lipid peroxidation mainly relies on a direct chemical reaction between ascorbic acid and $\alpha$-tocopherol where electrons are transferred from one molecule to the other. $\alpha$-Tocopherol scavenges free radicals that are produced in the lipid membrane, and is oxidized to the $\alpha$-tocopheroxyl radical. The $\alpha$-tocopheroxyl radical is reduced by ascorbic acid that serves as a radical sink in the water phase.

Bioactives modulate the inflammatory process mainly via an effect on signaling cascades and transcription factors. Therefore, interactions between compounds during inflammation will not be as direct as those observed during lipid peroxidation.

It was also observed in the study described in chapter 3, that lycopene in isolation exhibited strong anti-inflammatory properties, which was not greatly affected by ascorbic acid and/or $\alpha$-tocopherol. These findings indicate that lycopene plays a key role in inhibiting inflammation whereas ascorbic acid and $\alpha$-tocopherol are important for the protection against lipid peroxidation. Both activities are complementary since they diminish the process of inflammation on different levels.

The inflammatory process involves several inflammatory key processes, of which activation of the transcription factor NFKB is of pivotal importance $(6,27,28)$. NFKB is activated when its inhibitor protein $1 \mathrm{~KB}$, is phosphorylated by the enzyme PKC. PKC consists of several isoforms, of which the isoforms $\alpha, \beta I$ and $\delta$, regulate the downstream pathway of $\operatorname{NF\kappa B}$ activation $(29,30)$.

In chapter 4 the capability of $\alpha$-tocopherol, and the carotenoids lycopene, $\beta$-carotene and lutein to inhibit the activity of the PKC isoforms $\alpha, \beta I I$ and $\delta$, was investigated. In accordance to literature data, $\alpha$-tocopherol inhibited PKC- $\alpha$. Our results also demonstrated that PKC- $\beta$ II and PKC- $\delta$ are inhibited by $\alpha$-tocopherol. The inhibitory effect on several isoforms demonstrates the versatile role of $\alpha$-tocopherol in mitigating the inflammatory response. The carotenoids lycopene, $\beta$-carotene and lutein inhibited PKC- $\alpha$, PKC- $\beta \mathrm{II}$ and PKC- $\delta$ activity in the same order of magnitude as $\alpha$-tocopherol. The anti-inflammatory potential was confirmed by the reduced PKC activity in cultured endothelial cells. Apparently, the biological effect of the tested carotenoids and that of $\alpha$-tocopherol on PKC overlaps. This overlap in PKC inhibition illustrated the potential cooperation of phytochemicals which are abundantly found in fruits and vegetables, on pivotal cellular processes, such as the prevention of NFKB activation. Subsequently, the effect of tomato ketchup on sequential inflammatory processes during 
human monocyte-endothelial cell interactions was studied in chapter 5 . Tomato ketchup mitigated the initial phase of the inflammatory process by reducing the gene expression of $1 \kappa B$ which is a marker for less activation of the transcription factor NFKB. The reduced activition of NFKB was confirmed by the decreased gene expression of the pro-inflammatory cytokines TNF- $\alpha$ and IL-8, which is controlled by NFKB. Tomato ketchup also inhibited the release of IL- 8 and TNF- $\alpha$. Tomato ketchup had more effect on the release of the anti-inflammatory cytokine IL-10 than on its gene expression. This implies that tomato ketchup affects the antiinflammatory feedback control via another mechanism than its gene expression.

Pro-inflammatory cytokine production leads to the process of chemotaxis. This is the recruitment and migration of monocytes to the inflamed site in the vessel wall. Chemotaxis also involves the expression of adhesion molecules by the vascular endothelium. Tomato ketchup effectively reduced gene expression of the adhesion molecules E-selectin and ICAM-1 and monocyte migration. The results consistently emphasize the major contribution of lycopene to the anti-inflammatory effect of tomato ketchup. Other compounds in tomato ketchup such as $\alpha$-tocopherol and ascorbic acid appeared to strengthen the anti-inflammatory effect of lycopene. Tomato ketchup subtly interfered on several inflammatory processes that was integrated in a clear inhibitory effect on chemotaxis. Such a pleotropic mode of action can especially be effective in mitigation of diseases characterized with prolonged and low grade inflammation. Based on the promising results of the current study, we further investigated the potential anti-inflammatory effects of tomato ketchup in humans, as described in chapter 6. Healthy volunteers consumed a single meal with tomato ketchup. Subsequently, their blood was ex-vivo stimulated with an inflammatory stimulus (lipopolysaccharide (LPS)) in order to mimic an inflammatory response. The ex-vivo LPS stimulus will elicit the production of inflammatory cytokines (TNF- $\alpha$, IL- 8 and IL-10). Moreover, the ability to adapt to the inflammatory stimulus was tested with a functional chemotaxis bioassay.

Our experiments showed that tomato ketchup consumption effectively reduced TNF- $\alpha$ production and tended to reduce IL-8 release. However, tomato ketchup did not alter IL-10 release. The assessment of individual cytokines covers only a relatively small part of the inflammatory response. Interestingly, the effect of the tomato ketchup was relatively large on monocyte migration, tested by means of a functional chemotaxis bioassay. This bioassay reflects the interaction of all inflammatory mediators present in the volunteers blood with monocytes, and was used to determine the effect of the tomato ketchup intervention on a pivotal pathophysiological process, namely chemotaxis. The reduced chemotaxis after the intervention indicated that tomato ketchup improves the ability of healthy volunteers to increase their anti-inflammatory resistance. These findings suggest the health potential of tomato ketchup. 


\section{Implications and further research}

The studies demonstrate the antioxidant and anti-inflammatory potential of tomatoes and tomato products. The studies also demonstrate some practical aspects for nutritional studies. Although much attention is given to lycopene, also $\alpha$-tocopherol and ascorbic acid contribute to the health effect of tomatoes and additive as well as synergistic interactions between bioactive compounds were found. This means that to accurately assess the effect of nutrition, research should not only focus on isolated bioactives but also on the whole food matrix in which all bioactives are present.

The studies also illustrate that the effect of compounds is not due to a major effect on a single target, it is rather achieved by a myriad of subtle effects on inter connected targets, that combined can give a physiological relevant effect. The consequence is that the health benefit is best studied in bioassays that integrate these processes. The studies show that the chemotaxis assay suits this purpose and the results obtained with his bioassay nicely illustrate the health potential of tomato ketchup.

The concept of health has been extende and now includes 'the ability to adapt'. This concept is difficult to evaluate, especially in healthy volunteers. An ex-vivo challenge with LPS proved to be successful and demonstrated the increase in the ability to adapt by tomato ketchup.

Since nutrition does not contain only one bioactive compound, but a wide variety, it would be more realistic to study the effects of the whole food matrix in which all bioactives are integrated. Interestingly, it is very common to consume tomatoes and tomato products mostly in combination with other food products such as olive oil and onions that have the potency to optimize the health benefits of tomatoes.

This thesis contributed to elucidate potential health benefits of tomatoes and tomato products, respectively. Based on the results obtained, several research questions for further research come to mind:

- Does enrichment of tomato ketchup and tomatoes with nutritional compounds from other food products such as olive oil and onions enhance the anti-inflammatory potential?

- The bioavailability of lycopene is increased by the addition of (olive) oil. Moreover, olive oil contains the antioxidant hydroxytyrosol, which protects against LDL oxidations.

- Onions contain the bioactive compound quercetin, which has antioxidant and anti-inflammatory activities.

- Do tomato ketchup and tomatoes have a direct health benefit in patients with chronic inflammatory diseases? 
- What is the interaction of bioactive compounds in tomatoes with medication used in chronic inflammatory diseases (CVD, hypertension, cancer, osteoporosis)?

- What is the optimal tomato intake and what is the difference for different populations e.g. children, adolescents, elderly, patients with chronic inflammatory diseases?

- Are the anti-inflammatory benefits of tomato ketchup increased when the sugar content is reduced or substituted with sugar replacements? 


\section{References}

1. Kundu JK, Surh YJ. Inflammation: gearing the journey to cancer. Mutat Res. 2008 Jul-Aug;659:15-30.

2. Tesfamariam B, DeFelice AF. Endothelial injury in the initiation and progression of vascular disorders. Vascul Pharmacol. 2007 Apr;46:229-37.

3. Levin NW, Ronco C. Chronic inflammation: an overview. Contrib Nephrol. 2002:364-70.

4. Lowe GD. The relationship between infection, inflammation, and cardiovascular disease: an overview. Ann Periodontol. 2001 Dec;6:1-8.

5. Zeng L, Webster SV, Newton PM. The biology of protein kinase C. Advances in experimental medicine and biology. 2012;740:639-61.

6. Diaz-Meco MT, Moscat J. The atypical PKCs in inflammation: NF-kappaB and beyond. Immunol Rev. 2012 Mar;246:154-67.

7. Gamble C, McIntosh K, Scott R, Ho KH, Plevin R, Paul A. Inhibitory kappa B Kinases as targets for pharmacological regulation. BrJ Pharmacol. 2012 Feb;165:802-19.

8. Shi C, Pamer EG. Monocyte recruitment during infection and inflammation. Nat Rev Immunol. 2011 Nov;11:762-74.

9. Surmi BK, Hasty $\mathrm{AH}$. The role of chemokines in recruitment of immune cells to the artery wall and adipose tissue. Vascul Pharmacol. 2010 Jan-Feb;52:27-36.

10. Galkina E, Ley K. Immune and inflammatory mechanisms of atherosclerosis (*). Annual review of immunology. 2009;27:165-97.

11. Bohm V. Lycopene and heart health. Molecular nutrition \& food research. 2012 Feb;56:296-303.

12. Koenig W. Inflammation and coronary heart disease: an overview. Cardiol Rev. 2001 Jan-Feb;9:31-5.

13. Palaniswamy C, Selvaraj DR, Rao V, Patel U. Newer therapies for osteoporosis. Am J Ther. 2010 Mar-Apr;17:197-200.

14. C.G.M. Heijnen GRMMH, A. Bast. The effect of flavonol-enriched tomato paste on blood pressure in sponteneously hypertensive rats. Maastricht; 2001.

15. de Leeuw PW, Bast A. Tomato extract for hypertension? Editorial to "The effects of natural antioxidants from tomato extract in treated but uncontrolled hypertensive patients" by E. Paran et al. Cardiovascular drugs and therapy / sponsored by the International Society of Cardiovascular Pharmacotherapy. 2009 Apr;23:107-8.

16. Paran E, Novack V, Engelhard YN, Hazan-Halevy I. The effects of natural antioxidants from tomato extract in treated but uncontrolled hypertensive patients. Cardiovascular drugs and therapy / sponsored by the International Society of Cardiovascular Pharmacotherapy. 2009 Apr;23:145-51.

17. Mackinnon ES, Rao AV, Josse RG, Rao LG. Supplementation with the antioxidant lycopene significantly decreases oxidative stress parameters and the bone resorption marker $\mathrm{N}$-telopeptide of type I collagen in postmenopausal women. Osteoporos Int. 2011 Apr;22:1091-101.

18. Mackinnon ES, Rao AV, Rao LG. Dietary restriction of lycopene for a period of one month resulted in significantly increased biomarkers of oxidative stress and bone resorption in postmenopausal women. J Nutr Health Aging. 2011 Feb;15:133-8. 
19. Palozza P, Parrone N, Simone R, Catalano A. Role of lycopene in the control of ROS-mediated cell growth: implications in cancer prevention. Curr Med Chem. 2011;18:1846-6o.

20. Campbell JK, Engelmann NJ, Lila MA, Erdman JW, Jr. Phytoene, Phytofluene, and Lycopene from Tomato Powder Differentially Accumulate in Tissues of Male Fisher 344 Rats. Nutr Res. 2007 Dec;27:794-801.

21. Ried K, Fakler P. Protective effect of lycopene on serum cholesterol and blood pressure: Meta-analyses of intervention trials. Maturitas. 2011 Apr;68:299-310.

22. Story EN, Kopec RE, Schwartz SJ, Harris GK. An update on the health effects of tomato lycopene. Annu Rev Food Sci Technol. 2010;1:189-210.

23. Palozza P, Parrone N, Catalano A, Simone R. Tomato lycopene and inflammatory cascade: basic interactions and clinical implications. Curr Med Chem. 2010;17:2547-63.

24. Rao AV, Agarwal S. Role of antioxidant lycopene in cancer and heart disease. Journal of the American College of Nutrition. 2000 Oct;19:563-9.

25. Niki E, Noguchi N, Tsuchihashi H, Gotoh N. Interaction among vitamin C, vitamin E, and beta-carotene. The American journal of clinical nutrition. 1995 Dec;62:1322S-6S.

26. Niki E. Interaction of ascorbate and alpha-tocopherol. Annals of the New York Academy of Sciences. 1987;498:186-99.

27. Rao P, Hayden MS, Long M, Scott ML, West AP, Zhang D, Oeckinghaus A, Lynch C, Hoffmann A, et al. IkappaBbeta acts to inhibit and activate gene expression during the inflammatory response. Nature. 2010 Aug 26;466:1115-9.

28. Hayden MS, West AP, Ghosh S. NF-kappaB and the immune response. Oncogene. 2006 Oct 30;25:6758-80.

29. Xia J, Matsuhashi S, Hamajima H, Iwane S, Takahashi H, Eguchi Y, Mizuta T, Fujimoto K, Kuroda S, Ozaki I. The role of PKC isoforms in the inhibition of NF-kappaB activation by vitamin $\mathrm{K}_{2}$ in human hepatocellular carcinoma cells. J Nutr Biochem. 2012 Apr 2.

30. Razani B, Reichardt AD, Cheng G. Non-canonical NF-kappaB signaling activation and regulation: principles and perspectives. Immunol Rev. 2011 Nov;244:44-54. 
Algemene discussie en
toekomstperspectieven 


\section{Algemene discussie}

Chronische inflammatie is een gecompliceerd biologisch proces dat uit verschillende cellulaire en sub-cellulaire reacties bestaat. Voorbeelden van dit soort processen en reacties zijn chemotaxie, cytokinen productie en gen-transcriptie. Een belangrijke oorzaak van chronische inflammatie is de productie van reaktieve zuurstof deeltjes (ROS) die het omringende weefsel, cellen en moleculen beschadigen. Een voorbeeld van de schade die deze ROS kunnen aanrichten, is de lipid peroxidatie van LDL. Als gevolg van weefsel- of celschade, worden signaleringsmoleculen zoals het enzym proteïne kinase $C$ (PKC) geactiveerd. PKC activeert op zijn beurt de

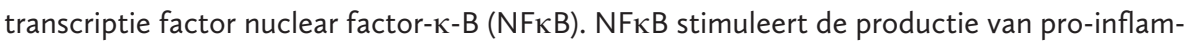
matoire cytokinen zoals TNF- $\alpha$ en IL-8.

Op de plaats van de ontsteking ontstaan hoge concentraties circulerende cytokinen die de chemotaxie op gang brengen. Het chemotaxie proces wordt gereguleerd door een geïntegreerd netwerk van inflammatoire cellen. Tijdens dit proces worden monocyten gerekruteerd naar de ontstekingshaard middels chemotactische factoren zoals IL-8 en monocyte chemotactic protein-1 (MCP-1) die door het endotheel op de binnenzijde van de bloedvatwand worden afgegeven. Op dit endotheel worden adhesie moleculen zoals inter cellular adhesion molecule-1 (ICAM-1), vascular cell adhesion molecule-1 (VCAM-1) en E-selectin zichtbaar gemaakt. Deze adhesie moleculen vergemakkelijken de binding van monocyten aan het endotheel, waarna de monocyten door de vaatwand van het endotheel migreren en differentiëren tot.

Chronische inflammatie kan de ontwikkeling van hart en vaatziekten (HVZ), kanker en osteoporose tot gevolg hebben (hoofdstuk 2). Het is gebleken dat tomaten een bescherming bieden tegen chronische inflammatoire aandoeningen. Het regelmatig eten van tomaten heeft een verlagend effect op de bloeddruk en het ontstaan van arteriosclerose in dieren en mensen. Bovendien heeft frequente consumptie van tomaten een positief effect op de botstructuur van osteoporotische patiënten. Daarnaast werd uit onderzoek bekend dat vooral de samenwerking tussen de verschillende stoffen in tomaten een beschermend effect hebben tegen de ontwikkeling van kanker.

Diverse studies hebben het gezondheidseffect van tomaten toegeschreven aan de grote variëteit aan bioactieve stoffen, zoals carotenoïden, vitaminen en flavonoiden die tomaten bevatten (hoofdstuk 2). Veel wetenschappelijke studies hebben zich vooral gericht op de effecten van geïsoleerde bioactive stoffen in tomaten. Van alle bioactieve stoffen komt de carotenoid lycopeen het meest voor in tomaten. Vandaar dat er voornamelijk onderzoek is 
gedaan naar de effecten van lycopeen. Aanvankelijk werden er antioxidant en anti-mutagene effecten geobserveerd. Recentelijk werd duidelijk dat lycopeen ook een anti-inflammatoire werking bleek te hebben.

Naast lycopeen zijn er ook andere belangrijke bioactive stoffen in tomaten, zoals de vitaminen $\alpha$-tocopherol en ascorbine zuur. Beide vitaminen zijn met name bekend vanwege de sterke antioxidant werking. Ook is bekend dat ascorbine zuur en $\alpha$-tocopherol in-vitro bescherming kunnen bieden tegen inflammatie. De beschermende werking van deze geïsoleerde bioactieve stoffen wordt versterkt in het bijzijn van andere bioactieve stoffen dat leidt tot additieve en synergistische interacties. Een bekend voorbeeld is de synergistische samenwerking tussen ascorbine zuur en $\alpha$-tocopherol dat lipid peroxidatie zeer effectief remt.

Tot op heden is er weinig kennis over de samenwerking tussen de belangrijkste bioactive stoffen in tomaten (lycopeen, ascorbine zuur en $\alpha$-tocopherol). In hoofdstuk 3 werden de effecten van lycopeen, ascorbine zuur en $\alpha$-tocopherol, in geïsoleerde en gecombineerde vorm, op lipid peroxidatie en inflammatie onderzocht. De geobserveerd synergistische werking tussen ascorbine zuur en $\alpha$-tocopherol bood een effectieve bescherming tegen lipid peroxidatie. Het mechanisme berust op een directe chemische reactie waarbij elektronen worden doorgegeven van de ene molecuul aan de andere. Hierbij vangt $\alpha$-tocopherol de vrije radicalen weg die in het cel membraan worden geproduceerd. Dit wegvangen zorgt ervoor dat $\alpha$-tocopherol geoxideerd wordt waarbij het $\alpha$-tocopheroxyl radicaal ontstaat. Het $\alpha$-tocopheroxyl radicaal wordt gereduceerd door ascorbine zuur dat zich in de waterige fase bevindt.

Bioactieve stoffen bieden bescherming tegen op het ontstekingsproces door met name in te werken op signaleringscascades en transcriptie factoren. Daardoor zijn de samenwerkingseffecten tussen de verschillende stoffen tijdens de inflammatie minder direct dan de effecten gericht op het direct wegvangen van vrije radicalen zoals bij lipid peroxidatie.

In hoofdstuk 3, werd ondermeer gevonden dat geïsoleerd lycopeen een sterke anti-inflammatoire werking had, waarbij ascorbine zuur en $\alpha$-tocopherol een minder sterk anti-inflammatoir effect vertoonden. Deze bevindingen indiceren dat lycopeen een zeer belangrijke rol speelt in de remming van ontstekingen, terwijl ascorbine zuur en $\alpha$-tocopherol een aanmerkelijk beschermend effect hebben tegen lipid peroxidatie. De effecten op beide processen zijn complementair aan elkaar en tonen aan dat inflammatie op verschillende niveaus wordt geremd.

Het ontstekingsproces bestaat uit verschillende inflammatoire fasen, waarbij de activatie van de transcriptie factor NFKB een essentiële rol speelt. NFKB wordt geactiveerd wanneer het gekoppelde remmings-eiwit, IKB, wordt gefosforyleerd door het enzym PKC. PKC bestaat uit 
verschillende isovormen. De PKC isovormen, $\alpha, \beta$ II en $\delta$, reguleren vooral het neerwaartse signaleringstraject dat leidt naar NFKB activatie.

In hoofdstuk 4 werd het eventueel remmende effect van $\alpha$-tocopherol en de carotenoïden lycopeen, $\beta$-caroteen en luteïne, op de activiteit van PKC- $\alpha$, $\beta$ II en $\delta$, onderzocht. $\alpha$-Tocopherol remde PKC- $\alpha$ in overeenstemming met de bestaande literatuur. De resultaten van deze studie toonden ook aan dat PKC- $\beta$ II en PKC- $\delta$ werden geremd door $\alpha$-tocopherol. Daardoor werd duidelijk dat $\alpha$-tocopherol een veelzijdige rol heeft en op diverse manieren beschermt tegen inflammaties. De carotenoïden lycopeen, luteïne en $\beta$-caroteen remden PKC- $\alpha, \beta$ II en $\delta$ op een gelijksoortige manier als $\alpha$-tocopherol. Het anti-inflammatoire effect van deze stoffen werd bevestigd door een verminderde PKC activiteit in gekweekte endotheel cellen. Uit dit onderzoek kwam naar voren dat het effect van $\alpha$-tocopherol en de carotenoïden op PKC activiteit samenvalt. Dit duidt op een potentiële samenwerking van bioactieve stoffen, waardoor effectieve bescherming geboden kan worden tegen NFKB activatie en dus inflammatoire aandoeningen.

In hoofdstuk 5 werd vervolgens het effect van tomaten ketchup op de verschillende inflammatoire processen in humane monocyt-endotheel-cel interacties bestudeerd. Tomaten ketchup remde een eerste fase binnen het ontstekingsproces af door de gen-expressie van $I \kappa B$ te remmen. IKB is een marker voor de transcriptie factor NFKB; wanneer de expressie van $1 \kappa B$ verlaagd is dan kan aangenomen worden dat ook de activatie van $N F \kappa B$ verlaagd is. De verminderde activatie van NFKB werd bevestigd door een verlaagde gen-expressie en productie van de pro-inflammatoire cytokinen TNF- $\alpha$ en IL-8, die beiden gereguleerd worden door NFKB. De tomaten ketchup had een sterker effect op de productie van de anti-inflammatoire cytokine IL-10 dan op de gen expressie van dit cytokine. Dit suggereert dat tomaten ketchup op verschillende manieren inwerkt op IL-10.

De productie van pro-inflammatoire cytokinen initieert het chemotaxie proces. Tomaten ketchup bleek een sterk remmend effect te hebben op de expressie van de adhesie moleculen E-selectin en ICAM-1 en op de migratie van monocyten door de vaatwand. Uit de resultaten kon geconcludeerd worden dat lycopeen een expliciet aandeel had in de anti-inflammatoire werking van tomaten ketchup. De andere onderzochte stoffen, ascorbine zuur en $\alpha$-tocopherol bleken het anti-inflammatoire effect van lycopeen zelfs te versterken.

Het remmende effect van tomaten ketchup op de verschillende individuele inflammatoire processen is subtiel. Al deze processen komen samen in chemotaxie waarbij het remmende effect van tomaten ketchup nog duidelijker zichtbaar word. Het veelzijdige effect van tomaten ketchup kan effectieve bescherming bieden aan chronisch inflammatoire aandoeningen. 
De resultaten van de studie uit hoofdstuk 5 vormden de basis voor een vervolg studie waarbij het anti-inflammatoire effect van tomaten ketchup in de mens werd onderzocht. Deze studie wordt beschreven in hoofdstuk 6, waar gezonde vrijwilligers een maaltijd met tomaten ketchup aten. Vervolgens werd er bloed bij deze vrijwilligers afgenomen dat ex-vivo werd blootgesteld aan een inflammatoire stimulus (lipopolysaccharide (LPS)), en veroorzaakte de productie van inflammatoire cytokinen zoals TNF- $\alpha$, IL- 8 and IL-10. Tevens werd het aanpassingsvermogen tegen externe stimuli van het lichaam onderzocht met een functionele chemotaxie test. De experimenten wezen uit dat de maaltijd met tomaten ketchup de productie van TNF- $\alpha$ in het bloed sterk verminderde en een neerwaartse trend werd geobserveerd voor de productie van IL-8. Tomaten ketchup had geen effect op de productie van IL-10.

Het bestuderen van de productie van individuele cytokinen omvat maar een relatief klein deel van het gehele inflammatoire proces. Opvallend genoeg was het effect van tomaten ketchup relatief groot op de migratie van monocyten of te wel het chemotaxie proces, dat bestudeerd werd met de functionele chemotaxie test. Dit bioassay weerspiegelde de interactie tussen alle aanwezige inflammatoire cellen in het LPS gestimuleerde bloed van de vrijwilligers en gekweekte monocyten. De afgenomen chemotaxie na de interventie toont aan dat een maaltijd met tomaten ketchup het aanpassingsvermogen tegen externe stimuli van gezonde vrijwilligers verbeterd, waardoor de afweer wordt vergroot. Hieruit kan worden geconcludeerd dat tomaten ketchup een potentieel gezondheidseffect heeft. 


\section{Toekomstperspectieven}

De studies beschreven in deze thesis wijzen op de mogelijke antioxidant en anti-inflammatoire effecten van tomaten en tomaat producten. Bovendien worden een aantal praktische aspecten voor voedingsgerelateerde studies beschreven. Ondanks dat er veel aandacht is voor de effecten van lycopeen, hebben ook ascorbine zuur en $\alpha$-tocopherol een belangrijk aandeel in het gezondheidseffect van tomaten, waarbij een combinatie van deze stoffen leidt niet alleen tot additie maar zelfs tot een synergistische samenwerking. Om nauwkeurig onderzoek te doen naar de effecten van voeding zou het daarom beter zijn om niet alleen geïsoleerde bioactieve stoffen te bestuderen maar om de gehele voedingsmatrix, waarin alle bioactieve stoffen geïntegreerd zijn, te onderzoeken.

Wat duidelijk naar voren komt uit de beschreven studies is dat de effecten van bioactieve stoffen zijn niet gericht zijn op één target. De uitwerking van bioactieve stoffen vloeit voornamelijk voort uit diverse subtiele effecten die gericht zijn op verschillende onderling verbonden targets, wat leidt tot een fysiologisch relevant resultaat. Dit heeft tot gevolg dat het gezondheidseffect van bioactieve stoffen wellicht beter bestudeerd kan worden in bioassays waarin fysiologiche processen geïntegreerd worden. Het gebruikte chemotaxie bioassay is hier een mooi voorbeeld van en weerspiegeld een geïntegreerd ontstekingsproces waarbij het gezondheidsbevorderend effect van tomaten ketchup helder zichtbaar wordt.

Het begrip 'gezondheid' is een dynamisch concept dat recentelijk werd uitgebreid met het 'aanpassingsvermogen van het lichaam'. 'Gezondheid' is een moeilijk te onderzoeken begrip, vooral als zo'n onderzoek gezonde mensen includeerd. Door het bloed van de gezonde vrijwilligers ex-vivo te stimuleren kon het lichamelijke aanpassingsvermogen, of te wel het begrip gezondheid, in deze thesis onderzocht worden. Bovendien bleek dat een maaltijd met tomaten ketchup het aanpassingsvermogen sterk verbeterde.

Omdat voeding niet bestaat uit één bioactieve stof maar uit zeer veel verschillende stoffen, zou het realistischer zijn om de effecten van een gehele voedingsmatrix waarin alle stoffen geïntegreerd zijn, te bestuderen. Tomaten en tomaat producten worden vrijwel altijd in combinatie gegeten met andere producten zoals olijf olie of uien. Het is bekend dat olijf olie en uien een beschermend effect bieden tegen chronisch inflammatoire aandoeningen, en kunnen wellicht het gezondheidsbevorderende effect van tomaten kunnen optimaliseren.

Deze thesis draagt bij aan het verklaren van de potentiële gezondheidseffecten van tomaten en tomaten producten. Gebaseerd op de resultaten van deze thesis kunnen er nog een aantal punten geformuleerd worden voor toekomstig onderzoek: 
- Zou het verrijken van tomaten ketchup en tomaten met voedingsstoffen afkomstig van andere producten zoals olijf olie of uien het anti-inflammatoire effect kunnen verbeteren?

- De bio-beschikbaarheid van lycopeen wordt vergroot door het toevoegen van (olijf) olie). Boven- dien bevat olijf olie het antioxidant hydroxytyrosol dat beschermd tegen LDL oxidatie

- Uien bevatten de bioactieve stof quercetine dat een effectieve antioxidant en antiinflammatoire werking heeft.

- Hebben tomaten ketchup en tomaten een direct gezondheidsvoordeel in patiënten die lijden aan chronisch inflammatoire aandoeningen?

- Wat zou de interactie zijn tussen bioactieve stoffen in tomaten en medicatie die gebruikt word ten behoeve van chronische inflammatoire aandoeningen (HVZ, kanker, osteoporose)?

- Wat zou de optimale hoeveelheid tomaten zijn, en wat zou het verschil zijn tussen populaties (kinderen, adolescenten, ouderen, patiënten met chronisch inflammatoire aandoeningen)?

- Zou het anti-inflammatoire voordeel dat tomaten ketchup heeft versterkt kunnen worden wanneer de huidige hoeveelheid suiker gereduceerd wordt of vervangen wordt door een suiker surrogaat. 



\section{List of publications}

The anti-inflammatory effect of lycopene complements the antioxidant action of ascorbic acid and a-tocopherol

Authors: Merel Hazewindus, Guido R.M.M. Haenen, Antje R. Weseler, Aalt Bast

Source: Food Chemistry, Volume 132, Issue 2, 15 May 2012, Pages 954-958

$\alpha$-Tocopherol, lycopene, $\beta$-carotene and lutein reduce the activities PKC- $\alpha, \beta$ II and $\delta$

Authors: Merel Hazewindus, Guido R.M.M. Haenen, Antje R. Weseler, Aalt Bast

Source: Biochemical and Biophysical Research Communications submitted

Protection against chemotaxis in the anti-inflammatory effect of tomato ketchup Authors: Merel Hazewindus, Guido R.M.M. Haenen, Antje R. Weseler, Aalt Bast Source: PLOS ONE submitted

The protective potential of tomato ketchup consumption on inflammation induced ex vivo in human blood

Authors: Merel Hazewindus, Guido R.M.M. Haenen, Antje R. Weseler, Aalt Bast

Source: British Journal of Nutrition submitted

Boosting the functional food characteristics of tomatoes

Authors: Merel Hazewindus, Guido R.M.M. Haenen, Antje R. Weseler, Aalt Bast In preparation

\section{Presentations}

Unilever Research Prize, October 2008, Vlaardingen, Netherlands

\section{Honours}

Unilever Research Prize, October 2008, Vlaardingen, Netherlands

Top 3 \% Award Maastricht University, October 2008, Maastricht, Netherlands

\section{Postdoctoral education}

Toxicologist, European Registered, 2012, Postgraduate Education in Toxicology, Wageningen, Netherlands 


\section{Curriculum vitea}

Merel Hazewindus was born on October the $15^{\text {th }} 1974$ in Reimerswaal. She switched her career as self-employed manager in 2004 to study Health Sciences at the University of Maastricht. In 2007 she graduated 'With Merit' in the Bachelors Bio-regulation and Movement sciences. In 2008, she concluded the Master Metabolism, Nutrition and Physical activity with 'Cum Laude'. During her Master, she studied human energy metabolism and gluconeogenesis after a protein rich diet in human volunteers and the differentiation of human fat cells and fat cell metabolism at the Department of Human Biology at the University of Maastricht. At the same University at the department of Toxicology, she studied the effect of flavonoids on PARP-1 activation, topoisomerase II and DNA repair. In 2008 she was awarded as Top 3\% student of the University of Maastricht and won the Unilever Research Prize. From 2008 to 2012, she has been working on her PhD project 'Tomatoes as functional foods' at the Department of Toxicology at the University of Maastricht. The project was in cooperation with the J.C. Heinz Company. During that period, she obtained her graduated as a European Toxicologist at the Postgraduate Education in Toxicology in Wageningen. 
quelqui un me demonde

comment je congois lo vie

surtout par ces temps-ci

je lui réponds.

ge ne peux que lo voir en rose

quelqu'un me demonde

qi jella persois encore sinsi

hors de mon paradis

je lui dis pour moi lo vie

c'est de la prose

prezadre le tepps

me foire des illusions

czoure dons le bor

foner dous les champs

appelle-moi naire

ne pas juger vite

tresser des morguerites

refuser d'être

sur le qui-vive

appelle-moi noïre

tu me regordes, t'approches de moi

quand tume prends doins, tes bros

to voiz.., tes terres sur les miennes, tu oses je vois lo vie en rose

ne pos juger vite

trepser des morquerites

refuser d'etre

sur le qui-rive

appelle-moi noirve

appelle-moi nöre 


\section{Dankwoord}

Pffff het zit erop!!!! De afgelopen 4 jaar zijn niet zonder slag of stoot gegaan. Vooral het niet 'thuis' kunnen zijn bij Rob en mijn hondjes in de prachtige bosrijke omgeving bij Antwerpen, heeft er ingehakt. Ondanks dat ben ik eindelijk tot inzicht gekomen dat wat ik heb gedaan uitzonderlijk is. Dit is te danken aan mijn enorme drive en ambitie. En ik kan nu zeggen: 'Ik kan het!'. Ondanks mijn eigen inzet had ik dit niet kunnen doen zonder de steun van een grote groep mensen rondom mijn 'thuis' en in Maastricht.

Vooral jij Rob, ja jongen ik benoem jou als eerste want zonder jou had ik helemaal geen doctor kunnen worden. Jij hebt ALTIJD in mij geloofd, zelfs als ik er zelf niet meer in geloofde. Je hebt me gesteund, aangemoedigd en getroost, wat ervoor gezorgd heeft dat ik dan toch maar weer op maandagochtend in de auto stapte met mijn koffertje om op donderdagavond weer terug te keren. Je bewaakte mijn rust en zorgde ervoor dat ik de afgelopen 4 jaar als een prinsesje heb kunnen leven. ledere keer wanneer ik liet zien waar ik mee bezig was zag ik dat je groeide van trots ondanks dat je er geen bal van snapte. Woorden schieten eigenlijk te kort... Thank you

\footnotetext{
If the sun refused to shine, I would still be loving you.

when mountains crumble to the sea, there would still be you and me.

Kind man, I give you my all, Kind man, nothing more.

Little drops of rain whisper of the pain, tears of loves lost in the days gone by.

Our love is strong, with you there is no wrong,

together we shall go until we die. My, my, my.

Inspiration's what you are to me, inspiration, look... see.

And so today, my world it smiles, your hand in mine, we walk the miles,

Thanks to you it will be done, for you to me are the only one.

Happiness, no more be sad, happiness... I'm glad.

If the sun refused to shine, I would still be loving you.

If the mountains should crumble to the sea, there would still be you and me.
}

Led Zeppelin

Papa, jij volgt je schoonzoon op in deze dankbetuiging. Het is eigenlijk aan jouw pessimisme te danken dat ik zo'n enorm doorzettingsvermogen heb ontwikkeld. Ik herinner me je gezicht nog en je twijfeling toen ik enthousiast vertelde dat ik ging studeren en de zaak ging verkopen. 
Ik wilde je laten zien dat ik het kon en dat failure not an option was (zie ook Mam-rita). Toen ik cum-laude afstudeerde en direct aan de slag kon als AIO viel je naast je stoel van trots. Toen wist ik: yes yes yes!! Daddies little girl has done it!!

Speciaal voor jou:

Cause if it wasn't for all that you tried to do, I wouldn't know just how capable I am to pull through So I wanna say thank you 'cause it

Makes me that much stronger Makes me work a little bit harder

Makes me that much wiser

So thanks for making me a fighter

Made me learn a little bit faster

Made my skin a little bit thicker

Makes me that much smarter

So thanks for making me a fighter

Christina Aguilera

Maar ook jij Rita, of liever Mam-rita, jij bent net als Rob: jij had er alle vertrouwen in dat me dit ging lukken. Dat failure not an option was wist jij al, weet je nog de tas die je voor me meenam uit Florida?? De gesprekjes met jou over het wel en wee als AIO, de wetenschap en de toekomst, opende vaak mijn starre blik. Daarom uit mijn hart voor jou:

She used to be my only enemy and never let me be free

Catching me in places that I knew I shouldn't be

Every other day I crossed the line

I didn't mean to be so bad

I never thought you would

Become the friend I never had

Back then I didn't know why

Why you were misunderstood (Mama)

So now I see through your eyes

All that you did was love

Mama I love you, Mama I care

Mama I love you, Mama my friend

You're my friend

I didn't want to hear it then but

I'm not ashamed to say it now

Every little thing you said and did was right for me

I had a lot of time to think about

About the way I used to be

Never had a sense of my responsibility 
Belindaatje mijn grote lange lieve vriendin!! En Ray natuurlijk, mijn lieve kleine vriend! Wat ben ik blij dat jullie deel uitmaken van ons leven. De heerlijke marathon-onzin-sms-jes en de cocktail avondjes met eigen gemaakte pizza's, en de diepzinnige gesprekken over eigenlijk niks, zijn uitermate belangrijk voor mijn gemoedstoestand (geweest). Jullie aanwezigheid op de achtergrond heeft er voor gezorgd dat ik dingen kon relativeren tijdens de afgelopen jaren. En Ray, jij hebt mijn ondernemerszin weer doen opbloeien. De onderstaande geweldige songtekst geldt dan ook voor jullie!

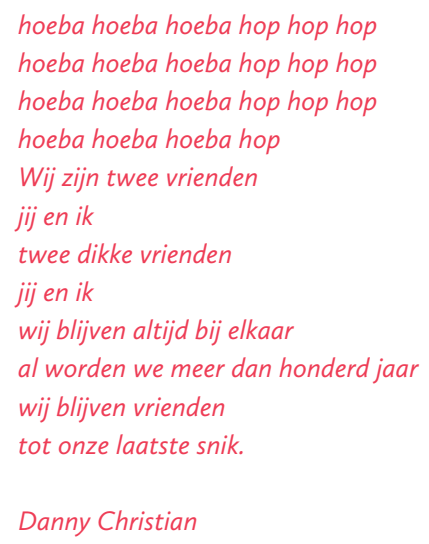

Suzanne, jou wil ik bedanken voor het je creatieve inzet bij het ontwikkelen van dit boekje. Het is precies zoals het moest worden.

Adri en Nelly, als jullie er niet waren geweest, waren de dingen thuis soms niet te organiseren. Altijd konden/kunnen we op jullie rekenen wat onze hondjes betreft. Of toen ik nog met de Saab naar Maastricht reed en het weer eens niet deed, kon ik met jullie auto rijden.

Peetje, mijn lieve lieve buuf. Ik weet dat je je regelmatig ongerust maakte over mij. In plaats van aan te bellen of over de schutting te roepen kreeg ik dan een mailtje of een sms waarin stond: Werk je niet te hard lieve buuf?? Ik zie je zo weinig ... kom je snel weer es koffie drinken? Ondanks dat ik ons contact met grote regelmaat verwaarloosde heb je er altijd begrip voor gehad, dank je. 
Ook wil ik verder alle Mannen van de BASF en hun aanhang bedanken. Misschien niet eens voor mezelf, maar vooral voor Rob.

Lieve Cath en Eric, ik ben blij dat jullie hier deel van uit kunnen maken. Je kleine zusje heeft het toch maar even gedaan!

Verder bedank ik alle mensen die hier niet aan bod zijn gekomen voor hun back-up en steun: een dikke thanx!!

Dan kom ik aan bij mijn Maastrichtse leven.

Wimmie en Erik ... tja wat valt er te zeggen ... :D mijn paranimfen! Ik ben zo blij dat jullie mij helpen en steunen (hopelijk niet teveel in de letterlijke zin van het woord op de dag des oordeels). Twee sterke mannen, alhoewel ... hahaha. Wim, bedankt man, als ik weer es op facebook riep dat ik het niet meer zag zitten dan kwam er gelijk een bericht: komt goed. En Erik, we moeten dat echt eens serieus gaan bekijken hoor met die steriele epjes.

Esthertje, ik zal je missen, en ik mis je eigenlijk al. We hebben heel veel gelachen; je bent de helium ballon vast nog niet vergeten!! Ik hoop dat ik de belofte kan waarmaken dat ik of jou kant op kom of dat jullie onze kant opkomen!

En dan Hilde, sorry dat je jezelf hier pas tegen komt, maar dat betekent niet dat je minder belangrijk bent! Net als ik behoorde jij ook tot de 'harde kern' if you know what I mean ... Ik heb enorm veel steun aan je gehad. Ik ben blij dat je mijn reserve paranimf wilt zijn. Als ik vragen had, dan kon je die beantwoorden. En ik moet zeggen dat ik goed gekeken heb naar de lay-out van jouw boekje, ook zo'n meesterwerk. Ik hoop dat we ons contact kunnen behouden.

Jiska, mijn lieve kamergenootje. Ik hoop voor jou dat je niet te lang alleen zit, want ik heb je vaker alleen laten zitten. Sinds ik thuis aan het boekje heb gewerkt heb ik je wel gemist hoor, onze small talk die af en toe behoorlijk lang en diepzinnig konden worden. Ik ben erg benieuwd wat de toekomst jou gaat brengen.

Agnes, dank voor alle steun en peptalk die je me hebt gegeven. Dit geldt trouwens ook voor Els. Els ik zal nooit vergeten dat je me een aantal keren hele goede raad hebt gegeven. Jammer dat ik maar zo kort heb gewerkt met jullie beiden.

Rogerke, de geboren organisator en gangmaker! Ik weet nog de dag dat ik begon bij Tox. Jij was eigenlijk de eerste die me een beetje op mijn gemak stelde. En als ik nu de gang in loop en je ziet me is het eerste wat ik hoor: MERELTJE!!! Ik had nooit gedacht dat we samen het 
lab op zouden gaan, maar toch, pas in mijn laatste jaar! Dat hadden we veel eerder moeten doen, toen werd het pas leuk. Maar ook naast het werk moet ik je een warm hart toedragen. Je bent altijd de gangmaker tijdens de etentjes, uitjes en borrels. En dat niet alleen, ook met serieuzere dingen kon ik bij je terecht, wat ik heel fijn vond. Dank je, dank je.

Kristien, net als ik een festival fan, alleen dan een iets ander genre. Jij kunt het ook! Echt, daar ben ik van overtuigd. Max, hèhèhèhè mijn boekje is lekker eerder klaar dan dat van jou. Jouw technische kennis wat I-phone betreft zal ik nooit vergeten J. Bregje, ik hoop dat je je rijbewijs haalt voor je gepromoveerd bent I maar dat moet lukken, anders zullen we wel eens een extra les in de Mini inlassen. Joy, ik heb ze nog steeds hoor de toffe Adidas sneakers, heb je al gekeken op Mi Adidas, kun je ze helemaal naar je zin customizen. Gert-Jan, net als ik een sportfanaat (of is dat nu weer te overdreven? Niet in mijn geval). Danielle, mijn buurvrouw, ik ben blij dat je altijd het geduld hebt gehad om me iets uit te leggen. Grote dank aan jullie allen.

Agnieska, I hope the following is translated in good order, otherwise I'll hope you will get the message. Szanowni Państwo Agnieska, Chcę podziękować za konwersacji inspirującym, cieszyć się papieros. Mam nadzieję, że możemy nadal można przechowywać kontakt, zawsze Zapraszamy do nas.

Ook wil ik graag iedereen van de beoordelingscommissie bedanken voor het lezen en beoordelen van dit proefschrift.

Verder wil ik Akke bedanken voor alle secretariële zaken gedurende de afgelopen jaren. En Marie Claire natuurlijk: jij hebt me zo geholpen bij het maken van brieven en afspraken die nodig waren voor de beoordeling en de verdediging van dit proefschrift. Natuurlijk wil ik jullie ook bedanken voor alle persoonlijke interesse in mij.

En dan kom ik aan bij het team dat een groot aandeel heeft in de ontwikkeling van de inhoud van dit boekje en het succesvol afronden van dit project.

Ik wil graag Dick van Olderen, Anna Maria Hilbers, Machteld van Lieshout en Ida Marie Laquatra van J.C. Heinz bedanken voor het tot stand komen van dit proefschrift. Het was een erg prettige samenwerking.

Antje, ik weet dat onze samenwerking niet altijd even vlot verliep, wat waarschijnlijk kwam door onze totaal verschillende persoonlijkheden en opvattingen. Jouw perfectionisme heeft mij doen inzien dat mijn perfectionisme eigenlijk niets voorstelt. Achteraf moet ik zeggen dat ik veel van je heb geleerd. Zonder jouw kritische opmerkingen en ideeën had dit boekje er vast heel anders uitgezien. 
Guido, er gaan nu een heleboel dingen door mijn hoofd die ik maar beter niet in dit proefschrift kan zetten hahahaha. Maar ik als ik aan jou denk, zie ik in grote letters GRATIS. Dat geeft aan dat we wel een hele leuke samenwerking hebben gehad. Ik heb eigenlijk nooit gedacht: pff wat een zeur, of, grrr daar gaan we weer. Ondanks dat ik voor de drie duizendste keer iets mailde en het weer moest aanpassen. Ik heb bewondering voor de manier waarop je mijn hersens prikkelde en me nieuwsgierig maakte. Dit heeft me enorm gemotiveerd. Ik heb buitengewoon veel van je geleerd, niet alleen over het bedrijven van wetenschap, maar ook over algemene zaken.

Professor Aalt Bast, (nu moet ik eigenlijk 'U' gaan zeggen) het is zover, ik ben nu Doctor Merel Hazewindus. Ik denk dat je als promovendus haast geen fijnere promotor kunt treffen als jij. Ik wil je bedanken voor je support en je sturing op de momenten dat ik het even niet meer wist. Dankzij jou ben ik van een wetenschappelijke puber gegroeid naar een wetenschappelijke adolescent. Ik zal nog vaak gaan terug denken aan de vele fijne gesprekken en niet te vergeten de vele grappen die gemaakt werden tijdens de wbs-sen.

Natuurlijk ben ik mensen vergeten te benoemen, mocht je je aangesproken voelen, bedenk dan dat je me hier altijd op kunt wijzen. Ik kan helaas je naam niet meer toevoegen in het dankwoord. Sorry daarvoor. 
...

$\frac{\pi}{p}$ am a giant

$\frac{\pi}{\pi}$ am an eagle

$\frac{\pi}{x}$ gm a lion

Down in the jungle

I 8 ma marching bond

Is am the people

Tom o helping hond.

I am a hero

If anybody asks a who I am Just stand up toll

Cook em in the face and soy

TIm that stor up in the shy It that mountain peak up high Hey I mode it Ifs the world's greatest And I' $m$ that little bit of hope When my backs gooiest the ropes $\frac{\pi}{\pi}$ con feel it

If the world's greatest

It the ring of life, TIll rein love And the world will notice o king When all is darkest I'll shine g light And you'll use the success you'll find in me

R. KELLY 